\title{
Assessing Financial Access in Brazil
}

Anjali Kumar

Thorsten Beck

Cristine Campos

Soumya Chattopadhyay

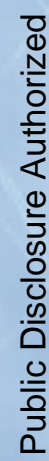





\title{
Assessing Financial Access in Brazil
}

\author{
Anjali Kumar \\ Thorsten Beck \\ Cristine Campos \\ Soumya Chattopadhyay
}

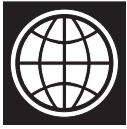

THE WORLD BANK

Washington, D.C. 
Copyright (C) 2005

The International Bank for Reconstruction and Development/The World Bank

1818 H Street, N.W.

Washington, D.C. 20433, U.S.A.

All rights reserved

Manufactured in the United States of America

First Printing: April 2005

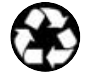

printed on recycled paper

\section{5}

World Bank Working Papers are published to communicate the results of the Bank's work to the development community with the least possible delay. The manuscript of this paper therefore has not been prepared in accordance with the procedures appropriate to formally-edited texts. Some sources cited in this paper may be informal documents that are not readily available.

The findings, interpretations, and conclusions expressed herein are those of the author(s) and do not necessarily reflect the views of the International Bank for Reconstruction and Development/The World Bank and its affiliated organizations, or those of the Executive Directors of The World Bank or the governments they represent.

The World Bank does not guarantee the accuracy of the data included in this work. The boundaries, colors, denominations, and other information shown on any map in this work do not imply and judgment on the part of The World Bank of the legal status of any territory or the endorsement or acceptance of such boundaries.

The material in this publication is copyrighted. Copying and/or transmitting portions or all of this work without permission may be a violation of applicable law. The International Bank for Reconstruction and Development/The World Bank encourages dissemination of its work and will normally grant permission promptly to reproduce portions of the work.

For permission to photocopy or reprint any part of this work, please send a request with complete information to the Copyright Clearance Center, Inc., 222 Rosewood Drive, Danvers, MA 01923, USA, Tel: 978-750-8400, Fax: 978-750-4470, www.copyright.com.

All other queries on rights and licenses, including subsidiary rights, should be addressed to the Office of the Publisher, The World Bank, 1818 H Street NW, Washington, DC 20433, USA, Fax: 202-522-2422, email: pubrights@worldbank.org.

ISBN-10: 0-8213-6131-7 ISBN-13: 978-0-8213-6131-3

eISBN: 0-8213-6132-5

ISSN: $1726-5878$

DOI: $10.1596 / 978-0-8213-6131-3$

Anjali Kumar is Lead Financial Economist in the Finance cluster of the Latin American and Caribbean Region of the World Bank. Thorsten Beck is Senior Financial Economist in the Development Research Group at the World Bank. Cristine Campos is Consultant from the Instituto Pesquisa Economica Aplicada and the University of California, Berkeley. Soumya Chattopadhyay is Consultant to the World Bank.

Library of Congress Cataloging-in-Publication Data has been requested. 


\section{Contents}

Preface

1. Introduction

2. The Supply of Bank Services: Branches and Service Points 3

$\begin{array}{ll}\text { Regional Distribution of Financial Services } & 6\end{array}$

$\begin{array}{lr}\text { International Comparisons of Bank Services } & 8\end{array}$

Econometric Analyses of Factors Associated with Bank Service Supply $\quad 10$

Summary of Evidence from Supply Data on Banks and Financial Institutions 13

3. Users of Financial Services-A Survey of Urban Individuals 15

$\begin{array}{ll}\text { Survey Results-Access to Financial Institutions } & 16\end{array}$

$\begin{array}{ll}\text { Survey Results_-Deposits and Savings Behavior } & 18\end{array}$

$\begin{array}{ll}\text { Survey Results_Loans and Credit Services } & 19\end{array}$

Survey Results_-Payments and Money Transmission Services $\quad 21$

4. Analysis of Survey Results-What Explains Access? 23

The Impact of Location on Financial Access—Regions of the Country 24

Location in Terms of Micro Regions-Neighborhoods

and Areas within a City 24

The Role of Public and Private Institutions and Financial Access 26

The Role of Respondent Characteristics and Financial Access 28

Determinants of Access_-An Econometric Investigation 31

Determinants of Institutional Choice-Public versus Private Banks 34

5. Summary of Findings and Policy Implications 37

$\begin{array}{ll}\text { Implications for Policy } & 38\end{array}$

$\begin{array}{ll}\text { References } & 79\end{array}$

\section{APPENDIXES}

A. Note on Estimation: Urban Financial Survey 43

B. Statistical Tables 47 


\section{LIST OF TABLES}

1. Branch Density across Brazilian Regions 7

2. Provision of Bank Services across Regions 7

3. Provision of Bank Services across Municipalities (1996) 8

4. Public and Private Provision of Bank Services across Regions 8

5. Brazil-Bank Branch Density: International Comparisons 9

6. Brazil—What Explains Bank Branch Services across $\begin{array}{ll}\text { Municipalities? (All Banks) } & 10\end{array}$

7. Brazil-What Explains Public versus Private Bank Branch Services across Municipalities?

8. Indicator of Access: Access to Financial Institutions 17

9. Access to Loans and Credits 20

10. Access to Loans and Credits—Reasons for Loan Refusals 21

11. Econometric Results: Determinants of Access to Financial Services, Select Results $\quad 32$

12. Determinants of Access to Savings and Deposits Facilities 33

13. Econometric Results: Determinants of Volume of Credit Requested and Approved

14. Econometric Results: The Probability of Using Public Banks for Access, Deposits and Credit

15. Econometric Results: The Probability of Using Public Banks for Real Estate Purchase

B.1. Brazil-Number of Institutions in Operation and Assets (Year end 1993-2002)

B.2. Brazil—Bank Services: Aggregates, Branches, ATMs (Number of facilities in operation, year end 1994-2002)

B.3. Brazil-Number of Branches across Different Ownership Groups and over Time (1995-2001)

B.4. Brazil-Percentage Participation of Banking Institutions by Ownership and Institutional Type (1996-2001)

B.5. Brazil-Number of Financial Institutions in Operation by Region and Type (1999-2002)

B.6. Brazil-Bank Services by Region and Municipality:

Branches, PABs, and PAAs (1998-2002)

B.7. Brazil—Regional Indicators (2000)

B.8. Analysis of Supply-Economic and Financial Indicators across Brazilian States

B.9. Analysis of Supply_Branch Intensity a Cross Different Ownership Groups and over Time 
B.10. Analysis of Supply-Structure of the Loan Portfolio across Brazilian Banks over Time

B.11. Analysis of Demand-Urban Survey of Access and Geographic Location $\quad 64$

B.12. Analysis of Demand-Urban Survey of Access and Location 66

B.13. Analysis of Demand-Urban Survey of Access to Financial Institutions 68

B.14. Analysis of Demand-Urban Survey of Access to Deposit, Payment, and Credit Facilities

B.15. Analysis of Demand-Urban Survey of Access to Pension Deposits and Housing Finance

B.16. Analysis of Demand-Urban Survey on Use of a Financial Institution, Physical Access, and Deposit Facilities

B.17. Analysis of Demand-Urban Survey of Loans and Credit and Payment Services 76

\section{LIST OF FIGURES}

1. Brazil: Growth of Financial Institutions (1993-2002)

2. Brazil-Evolution of Financial Service Outlets (1994-2002)

3. Brazil-Ownership of Bank Service Points

4. Brazil and Other Countries-Population Served per Bank Branch 9

5. Deposit and Saving Behavior-Survey of Urban Individuals 18

6. Role of Location in Financial Access 25

7. The Role of Income in Different Measures of Financial Access 30

\section{LIST OF BOXES}

Bank Branch and Service Outposts in Brazil

Brazil Financial Access Urban Survey-Socio-economic Characteristics of Respondents

Individual Characteristics, Asymmetric Information and Access to Financial Services 



\title{
Preface
}

\begin{abstract}
A ccess to financial services in Brazil has been relatively stable over the past ten years, despite the banking sector contraction of the latter 1990s. Wide geographic variations in the supply of banking services by region and municipality are partly explained by differentials in income and population density. On a cross-country basis Brazil does not appear to be under banked. Looking at the use of financial services by different groups of consumers in Brazil, differences in financial access across regions is confirmed. However, differences among richer or poorer neighborhoods can be as important as differences between regions. Public financial institutions in Brazil, deemed to be socially responsible, appear to have served disadvantaged groups more than private banks on some measures and for some services. However their role varies by the type of service. In the case of some services, public banks may have served the better-off. At the level of individuals, the most important determinants of access to financial services are socio-economic characteristics such as income, wealth and education. This may signify that in the presence of asymmetric information, access to such services depends critically on client information, and such characteristics provide a proxy for creditworthiness.

The Central Bank of Brazil provided data on financial institutions and Rosane Mendoça of IPEA coordinated the organization of the survey of users of financial services in urban Brazil and the analysis of its data. We are grateful for research assistance provided by Adam Parsons and Ricardo Gonçalves. Findings, interpretations, and conclusions of this paper are entirely those of the authors and do not necessarily represent the views of the World Bank, its Executive Directors, or the countries they represent.
\end{abstract}



$\mathrm{I}$

$\mathrm{t}$ is increasingly accepted that greater financial system depth and soundness contribute to economic growth and poverty reduction by enabling better selection and monitoring of projects, diversifying risks, and encouraging the optimization of scale, time frame and technology. ${ }^{1}$ Strong financial systems also help absorb shocks and prevent financial crises which entail huge fiscal costs that crowd out social spending.

Beyond the association of financial depth and stability with growth and crisis prevention, the financial system may also be able to accelerate the reduction of poverty through broadened distribution of financial services. The improvement of access to financial services should help both consumers and producers raise their welfare and productivity. Individuals can insure themselves against periods of low income or unexpected fluctuations in income, and maintain their consumption standards through the accumulation of financial savings. ${ }^{2}$ Savings also provide a vehicle for future lumpy expenditure needs, whether expected (for example for special family occasions, or for the purchase of significant assets such as a home) or unexpected. Access to savings and borrowings could also have longer term welfare implications, permitting people to borrow when young, for example for education or for other physical or human capital, and then repay and save for retirement when they are older. ${ }^{3}$

1. Discussions of the association between growth and poverty reduction may be found in Dollar and Kraay (2001). The discussion of the association between growth and the financial system can be traced through King and Levine (1993); Rajan and Zingales (1998), Levine, Loayza and Beck, (2000), and World Bank (2001). See also IMF working paper by Holden and Prokopenko (2001), for a well-documented survey of the literature.

2. The role of savings and borrowing in protecting consumption against unexpected shocks, first discussed by Friedman (1957) in the 'permanent income hypothesis' has since been extensively tested empirically, as discussed in Bond and Townsend (1996).

3. The 'life cycle' hypothesis as an explanation for savings and borrowing behavior, discussed in Ando, Modigliani and Brumberg in a series of articles in the 1950s and 1960s. Mayer (1972), and Romer, (1996) have reviews. 
For a producer, access to credit for fixed or working capital enables an increase in production possibilities which can have far-reaching implications not only for the producer but for patterns of employment, occupational choice and even economy-wide productivity and growth. Financing constraints have been shown to feature prominently among the constraints of small and medium-size enterprises in some investigations. ${ }^{4} \mathrm{~A}$ study of Latin American firms found the difficulty of access to financial markets to be the major obstacle to the expansion of business activities, ahead of factors such as macro instability, taxes, and street crime. ${ }^{5}$ Another study of 15 Latin American countries demonstrated that access to financial services for microenterprises directly impacts poverty, due to the disproportionately large number of persons they employ (56 percent of all earners and 70 percent of the region's poor earners). In Brazil, an estimated 98 percent of registered firms are enterprises with less than 100 workers and account for about 45 percent of registered workers. ${ }^{6}$ These issues provide the motivation for the present paper, which investigates current patterns of access to financial services in Brazil, based on a series of alternative measurements, and examines the factors which explain differences in financial access across geographic areas and individuals. On one side, the Brazilian financial system is the largest in the region and offers a broad variety of services to its clients. On the other side, according to estimates, only around a third of the total population, or 58 million Brazilians have bank accounts, while some 80 million, or only half of the total population is considered "bankable." Central Bank statistics show that nearly 30 percent of all municipalities (about 1,680 municipalities, out of a total of some 5,600) have no bank branch. There are seven states (out of 27), mostly in the North and Northeast, where more than 70 percent of municipalities have no bank branches. Around 57 percent of all municipalities and nearly 20 percent of the population in these states have no access to a bank branch. ${ }^{8}$ The 1,400 or so credit cooperatives offer basic financial services only to about 1.5 million Brazilians, mostly in urban areas.

Chapter 2 investigates the extent to which the supply of banking services has increased or diminished over time, and also analyzes factors underlying the spatial distribution of banking services, and the relative roles of public and private banks. Chapters 3 and 4 look at the use of financial services by urban individuals and analyze factors accounting for differentials in access - in particular the importance of regional and local differentials in access, the role of public versus private financial institutions, and the role of individual characteristics that could serve as proxies for information on creditworthiness. The final chapter summarizes the findings of this paper.

4. Hallberg (2001).

5. Galindo (2001).

6. SEBRAE (Serviço Brasileiro de Apoio às Micro e Pequenas Empresas) website (January 2004).

7. In December 2002, there were 58.3 million savings accounts and 45.6 million current accounts in Brazil's banks, according to data maintained by the deposit insurance fund, FGC. FEBRABAN, the association of Brazil's banks, points out that estimates for current account numbers could be higher, since FGC excludes accounts in deficit. Assuming that some persons have only a current account while some others have only a savings account, the figure of 58.3 is thus a lower bound on the total number of bank account holders.

8. Not including correspondents. 


\section{The Supply of Bank Services: Branches and Service Points}

$\mathrm{H}$ ow has the supply of bank services changed over the last decade? Based on data provided by the Central Bank of Brazil, it appears true that there was a substantial contraction in the number of banks over the decade of the 1990s, in Brazil from 267 in 1993 to 194 a decade later in 2002 (Appendix Table B.1). Also, this was accompanied by some decline in the number of bank branches, from 17,400 in 1994 to 16,000 five years later in 1998 (Appendix Table B.2). These figures largely reflect the rationalization in the banking industry following inflation stabilization and consequent contraction in banks' float income, together with stricter prudential regulations on entry and operation, and later, the privatization of state banks. During this period, reliance on the banking system for service provision continued, with 92 percent of assets in the banking system in 1993, and 93 percent in 2001. A limited role was played by non-banks and this role did not shown any trend increase. Cooperatives increased in absolute numbers from around 500 in 1994 to over 1400 in 2002, though this was too small to affect bank dominance (Figure 1 and Appendix Table B.2). At a first glance these factors appear to suggest a reduction in availability of banking services.

A first qualification to this conclusion is that the apparent decline in bank services is reduced if banking portfolios of multiple banks are counted. Banking portfolios declined only from 334 to 296 between 1998 and 2001. Second, overall numbers of bank branches resumed growth after 1998 , to reach 17,050 by 2002 , so that over the period of a decade, branch numbers have been relatively stable. Recovery of the numbers of branches may reflect specific conditions governing bank mergers and buyouts especially for state-owned banks, and increased attention to income from credit operations. ${ }^{9}$ Third, the decline in

9. Bank mergers or purchases, especially with regard to the privatization of state banks under the PROES scheme, were frequently conditional on the maintenance of branch service provision. 
Figure 1. Brazil: Growth of Financial Institutions (1993-2002)

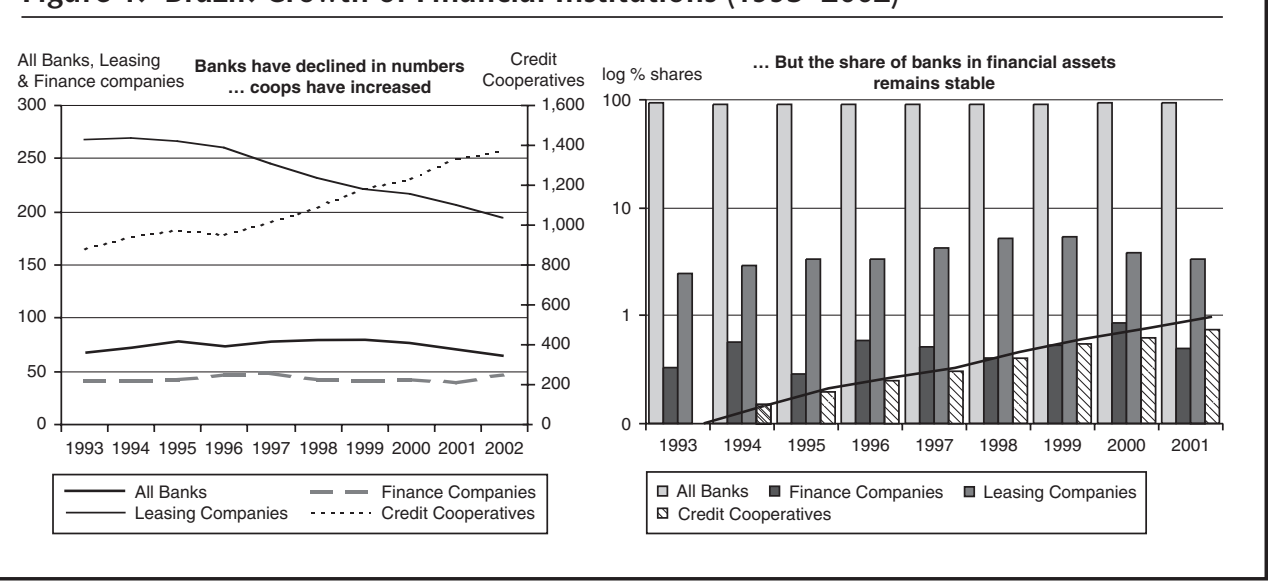

Source: Central Bank of Brazil.

bank branch numbers was accompanied by an expansion of new types of service points, especially towards automated teller machines. ATMs increased from 3,500 to 22,500 between 1994 and 2002 principally through the expansion of individual networks (from some 2,800 to over 20,000) and some smaller expansion of group-operated networks (from around 570 to 2,100 over the same period; see Figure 2). Municipalities with no branches but with PAAs doubled between 1998 and 2002 from 334 to 654 (Appendix Table B.2). More recently there was a striking increase in the numbers of 'correspondent' bank

\section{Bank Branch and Service Outposts in Brazil}

Brazilian branch regulation distinguishes between different types of branches and branch-like bank offices. At the top of the "hierarchy" is the agency, a bank branch that offers all services, but is also subject to relatively strict security requirements, branch hours, labor laws etc. The Posto Avançado Bancário (PAB) and Posto Avançado do Atendimento (PAA) are branch-like offices. PABs are similar to agencies, but provide services only to employees of the private enterprise or public institution, in which the PAB are physically located, and can determine their branch hours flexibly. PAAs (established by Resolution 2396/1997) are branch-like offices that can only be established in municipalities where the respective bank does not have an agência. The bank can determine branch hours, services offered and physical location. As of December 2002, there were 7,108 PABs and 654 PAAs in Brazil. However, more than 95 percent of all PABs were located in municipalities already served by bank branches. Finally, the ATMs (Posto de Atendimento Bancário Eletrônico, PAE), which have grown rapidly to 22,428 by end 2002, of which nearly 90 percent were on individual rather than associate networks, i.e., they allow access only to accounts with the owner bank.

In 1999, the Central Bank introduced the institution of banking correspondents (Resolutions 2640/1999 and 2707/2000). It allows banks to offer limited banking services via non-financial companies. Specifically, banks can offer payment and deposit services, and limited credit services. The financial responsibility, however, stays with the financial institution. By December 2002, there were over 16,000 correspondents sponsored by several federal and private banks, notably the lottery shop network of the publicly owned Caixa Econômica Federal and the postal office network concession won by Banco Bradesco, the largest private bank, in 2001. 
Figure 2. Brazil-Evolution of Financial Service Outlets (1994-2002)
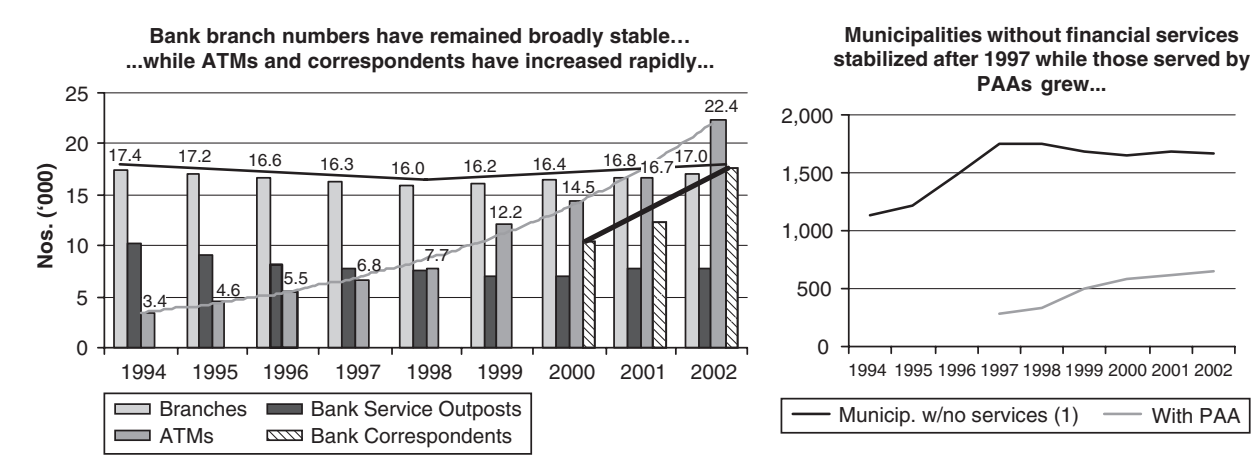

Source: Central Bank of Brazil.

arrangements from some 10,000 in the year 2,000, when correspondent arrangements were first enumerated, to some 16,500 by 2002 ; almost as numerous as bank branches. Apart from credit cooperatives, there has also been a growth in microfinance corporations (SCMs). From the six that were established in 1999, there were around 26 in operation at end of 2002 and an estimated 36 were close to formal start-ups. ${ }^{10}$

Further, looking at the municipality level, the numbers of municipalities with no bank branch services increased significantly from 1,137 to 1,749 between 1994 and 1997, (Appendix Table B.2). However this could be partly due to an increase in the numbers of municipalities, from 5,011 in 1994 to 5,597 by 1998 and further to 5,658 by 2002. After 1997, there was no further decline in municipalities without bank branches, and indeed there was some reduction in this number to 1,665 by end-2002.

In all, the data suggest that although there has been no marked decline in access to financial services over the past decade. The overall picture is relatively stagnant, barring some qualitatively significant new institutional segments (cooperatives and microcredit firms) and quantitatively more important development of new delivery channels. These positive signs accelerated after 1999.

In parallel, there were significant changes in the ownership composition of bank branches and other service points, with a huge decline in the proportion of public bank branches, which largely account for the faltering overall numbers of branch services (Figure 3). Branches of public banks fell from some 9,000 in 1995 to around 6,700 in 2001. However, branches of private and foreign banks almost doubled from some 5,400 to over 10,000 over the same period. ${ }^{11}$ Public banks rely to a greater extent on branches for delivery; ATMs accounted for only 31 percent of their outlets at the end of 2001, in contrast to almost 50 percent for private domestic banks (including banks with minority

10. Statistics for microfinance entities do not include those outside the formal financial system.

11. Although note that balance sheet data suggest that private domestic banks have less assets, loans and deposits per branch than federal banks (Appendix Table B.4). 
Figure 3. Brazil-Ownership of Bank Service Points
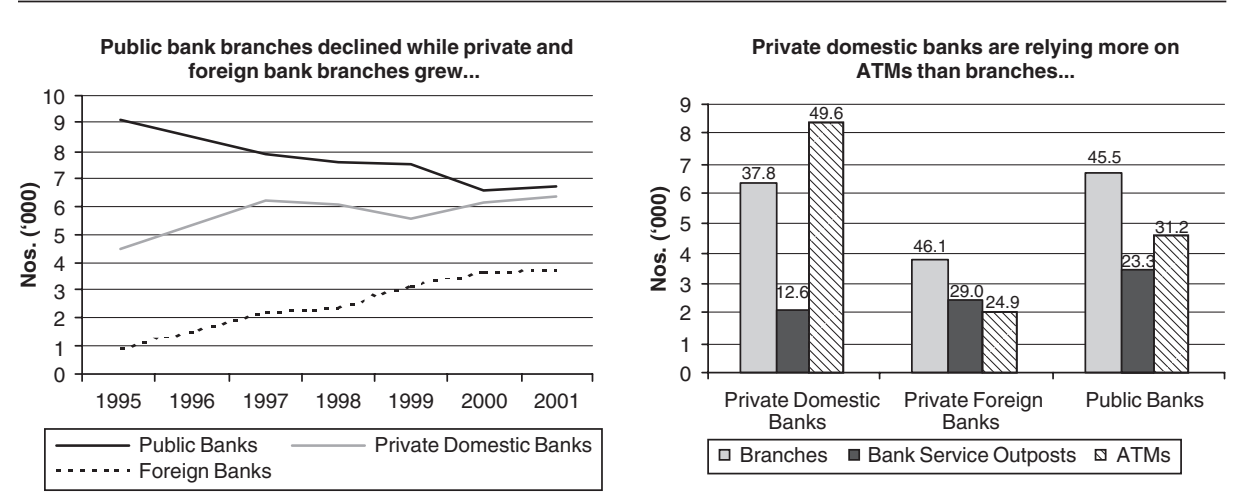

Note: Private domestic banks include those with foreign participation. Numbers correspond to December 2001 data unless stated otherwise.

Source: Central Bank of Brazil.

foreign ownership). These indicate that private banks made great strides in client outreach using delivery systems which are lower in cost and use newer technology. However wholly foreign owned banks had the lowest proportion of ATMs and the highest branch reliance, reflecting possibly their concentration in the high net worth segment. ${ }^{12}$

\section{Regional Distribution of Financial Services}

There are significant variations in service provision across different regions of the country (Table 1 and Appendix Table B.5). The population per bank branch was over thrice as high in the North as in the South of Brazil in 2000. Between 1996 and 2000, branch numbers declined in the North and Northeast, while they grew in the Southeast. However, branch numbers in all regions improved by 2002. And considering regional GDP differentials, the variation is substantially eroded. Indeed GDP per bank branch in the North is only 58 percent higher than in South although GDP per capita is nearly twice as high. The smaller number of branches in the North and Northeast therefore partly reflect lower income levels and hence less potential business. Bank presence exceeds what may be expected based on income differentials alone.

Using volumes of credit and deposits provided as an alternative measure of the supply of financial institutions, and adjusting these for income differentials, results still indicate

12. These changes in composition are also associated with changes in the delivery of different types of financial services. Public banks although with a low share in banking system net worth (a third in 1996), accounted for almost 60 percent of credit operations and over 60 percent of deposits in that year. By December 2001, the public banks' share of system net worth had declined to 16 percent and its share in credits to 25 percent, but it still accounted for 43 percent of all deposits (Appendix Table B.4). Foreign banks' shares in credit and net worth grew from around 10 percent to some 31 percent over the same period. 
Table 1. Branch Density across Brazilian Regions

\begin{tabular}{|c|c|c|c|c|c|c|c|c|c|}
\hline & $\begin{array}{c}\text { GDP/cap } \\
2000 \\
(\mathrm{R} \$)\end{array}$ & $\begin{array}{c}\mathrm{GDP} / \\
\text { branch } \\
(\mathrm{R} \$ \mathrm{~m}) \\
2000\end{array}$ & $\begin{array}{c}\text { GDP per } \\
\text { branch } \\
\text { (R\$m) } \\
1996\end{array}$ & $\begin{array}{c}\text { Popn/ } \\
\text { branch } \\
1996\end{array}$ & $\begin{array}{c}\text { Popn/ } \\
\text { branch } \\
2000\end{array}$ & $\begin{array}{c}\text { Branches } \\
1996\end{array}$ & $\begin{array}{c}\text { Branches } \\
2000\end{array}$ & $\begin{array}{c}\text { Branches } \\
2002\end{array}$ & $\begin{array}{c}\text { Area/ } \\
\text { branch } \\
2000 \\
\left(\mathrm{~km}^{2}\right)\end{array}$ \\
\hline North & 3,907 & 90.5 & 87.6 & 17,501 & 23,161 & 645 & 557 & 580 & 6,644 \\
\hline Northeast & 3,014 & 61.8 & 60.3 & 17,459 & 20,516 & 2,546 & 2,327 & 2,396 & 649 \\
\hline Southeast & 8,774 & 71.1 & 68.4 & 8,090 & 8,098 & 8,281 & 8,942 & 9,361 & 99 \\
\hline South & 7,692 & 57.2 & 56.0 & 6,835 & 7,437 & 3,440 & 3,376 & 3,450 & 167 \\
\hline Central West & 6,558 & 63.9 & 60.8 & 8,071 & 9,746 & 1,301 & 1,194 & 1,262 & 1,273 \\
\hline
\end{tabular}

Source: Branch data: Central Bank of Brazil. GDP data: IPEA, population and area data: IBGE.

substantial regional differences, especially between the North and Northeast compared to the Southeast (Table 2 and Appendix Table B.6). The variance in per capita credits and deposits is much larger than in credits/deposits relative to GDP; which may partly reflect differentials in regional inequality.

Such income differentials are more apparent looking at smaller geographic units, and thus not surprisingly, variations in the provision of bank services across municipalities is higher still (Table 3). Credits and deposits as a share of municipal GDP range from zero to over 1,000 percent. Similarly, credits and deposits per capita range from zero to $\mathrm{R} \$ 85,000$ (for credits) and $\mathrm{R} \$ 45,000$ for deposits. The large number of municipalities without any bank services explains why the average for the whole sample is so much lower than the aggregate for Brazil.

Is there any difference in the regional presence of public and private banks? The provision of bank services across regions clearly varies between private and public banks (Table 4). Public banks have dominated in the North and Northeast while private banks dominated in the Southeast. This could reflect the profit orientation of private and the "social" orientation of public banks. However data at the municipal level suggests some complementarity in the

Table 2. Provision of Bank Services across Regions

\begin{tabular}{lccccc}
\hline & $\begin{array}{c}\text { GDP per } \\
\text { capita (2000) }\end{array}$ & Credit/GDP & Deposits/GDP & $\begin{array}{c}\text { Credit } \\
\text { per capita }\end{array}$ & $\begin{array}{c}\text { Deposits } \\
\text { per capita }\end{array}$ \\
\hline North & 3,907 & 21.39 & 6.19 & 820 & 238 \\
Northeast & 3,014 & 19.69 & 24.14 & 500 & 613 \\
Southeast & 8,774 & 31.10 & 23.25 & 2,541 & 1,899 \\
South & 7,692 & 23.65 & 16.17 & 1,461 & 999 \\
Central West & 6,559 & 33.77 & 6.18 & 1588 & 291 \\
\hline
\end{tabular}

Note: Brasilia is excluded from the Central West region.

Source: Banco Central, IPEA and IBGE. 
Table 3. Provision of Bank Services across Municipalities (1996)

\begin{tabular}{lcccr}
\hline & Credit/GDP \% & Deposits/GDP \% & $\begin{array}{c}\text { Credits per } \\
\text { capita R\$ }\end{array}$ & $\begin{array}{c}\text { Deposits per } \\
\text { capita R\$ }\end{array}$ \\
\hline Average & 7.83 & 4.72 & 292 & 179 \\
Median & 2.12 & 2.82 & 36.71 & 45.11 \\
Standard deviation & 27.78 & 19.25 & 1,497 & 748 \\
Maximum & $1,458.24$ & $1,260.09$ & 85,335 & 44,631 \\
Minimum & 0 & 0 & 0 & 0 \\
Observations & 4,986 & 4,986 & 5,507 & 5,507 \\
Total Brazil & 30.49 & 22.32 & 1,774 & 1,298 \\
& & & &
\end{tabular}

Source: Estimated from data from the Banco Central.

branch structure of public and private banks. In 1996, 1,603 municipalities had just one branch either private or public, while 428 had two, three, or four branches entirely private or entirely public. In 2000, 1,393 municipalities had just one branch either private or public, while 397 had two, three, or four branches entirely private or entirely public. This suggests that there has been a pattern of segmented delivery of private and public banks, with limited competition between these segments in the more thinly served areas.

\section{International Comparisons of Bank Services}

Compared to developed economies, Brazilian bank branches serve a higher number of inhabitants per branch. While an average bank branch in Germany serves a population of 1,479 people and an American branch serves an area with 3,568 people on average, Brazilian branches served an average population of 9,331 people in 1996 and 10,356 in 2000 (Figure 4).

Table 4. Public and Private Provision of Bank Services across Regions

\begin{tabular}{lccccc}
\hline & $\begin{array}{c}\text { GDP per } \\
\text { capita (2000) }\end{array}$ & $\begin{array}{c}\text { Credit by } \\
\text { public } \\
\text { banks/GDP }\end{array}$ & $\begin{array}{c}\text { Credit by } \\
\text { private } \\
\text { banks/GDP }\end{array}$ & $\begin{array}{c}\text { Deposits } \\
\text { in public } \\
\text { banks /GDP }\end{array}$ & $\begin{array}{c}\text { Deposits } \\
\text { in private } \\
\text { banks /GDP }\end{array}$ \\
\hline North & 3,907 & 19.26 & 2.09 & 4.64 & 1.51 \\
Northeast & 3,014 & 14.73 & 4.89 & 19.14 & 4.97 \\
Southeast & 8,774 & 9.07 & 21.97 & 8.55 & 14.58 \\
South & 7,692 & 14.19 & 9.45 & 10.55 & 5.61 \\
Central West & 6,559 & 26.78 & 6.97 & 3.83 & 2.33 \\
\hline
\end{tabular}

Note: Brasilia is excluded from the Central West region.

Source: Banco Central, IPEA and IBGE. 
Figure 4. Brazil and Other Countries-Population Served per Bank Branch
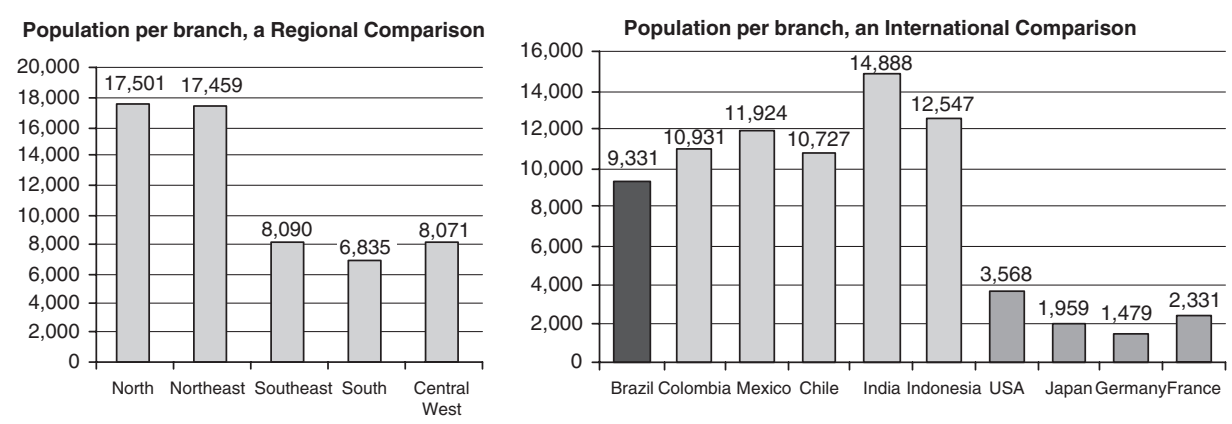

Source: World Bank staff estimates.

Yet, comparisons with other developing countries suggest that Brazil is not obviously under-branched (Table 5). First, Brazil has more bank branches relative to population than other Latin American countries and compared to two large developing countries: India and Indonesia. Second, measured relative to GDP, its bank branch intensity is lower than Colombia, India, and Indonesia, which are all poorer than Brazil, but the two latter are much more densely populated. Moreover, Branch intensity relative to GDP in Brazil is higher than in Mexico or Chile, although both are richer than Brazil.

Table 5. Brazil-Bank Branch Density: International Comparisons

\begin{tabular}{lccccc}
\hline & $\begin{array}{c}\text { GDP per } \\
\text { capita }\end{array}$ & $\begin{array}{c}\text { Population } \\
\text { per branch }\end{array}$ & $\begin{array}{c}\text { GDP per } \\
\text { branch (Current } \\
\text { USD millions) }\end{array}$ & $\begin{array}{c}\text { Area per } \\
\text { branch (sq km) }\end{array}$ & $\begin{array}{c}\text { Residual } \\
\text { branch } \\
\text { intensity }\end{array}$ \\
\hline Brazil & 3,152 & 9,331 & 29.4 & 470 & 0.82 \\
Colombia & 2,085 & 10,931 & 22.8 & 273 & -0.53 \\
Mexico & 4,969 & 11,924 & 59.3 & 236 & -0.42 \\
Chile & 4,505 & 10,727 & 48.3 & 535 & -0.79 \\
India & 448 & 14,888 & 6.7 & 44 & -0.00 \\
Indonesia & 683 & 12,547 & 8.6 & 110 & -0.07 \\
U.S. & 33,087 & 3,568 & 118.0 & 117 & -0.17 \\
Japan & 34,344 & 1,959 & 67.3 & 6 & 0.22 \\
Germany & 25,724 & 1,479 & 38.1 & 6 & 0.86 \\
France & 24,434 & 2,331 & 57.0 & 22 & 0.14 \\
& & & & &
\end{tabular}

Note: Residual branch intensity is the deviation of actual from predicted number of branches, derived from a regression of the number of branches on GDP, land area, and population for 28 countries. Positive numbers indicate that actual branch number exceed predicted values.

Sources: World Bank staff estimates, based on Hawkins and Mihaljek (2001) and World Development Indicator data. 
Third, measured according to average geographic area covered per branch, Brazil appears at first to be underbanked relative to all other comparator developing countries except for Chile. However, this is easily explained by the low population density of Brazil and the vast areas that are not populated. An econometric estimation of predicted branch intensity compared to actual intensity for Brazil and other countries, correcting for differences in branch intensity explained by differences in GDP, total population, and geographic size, finds that Brazil is the only developing economy that is not underbanked by this standard, because its actual branch intensity is higher than predicted.

\section{Econometric Analyses of Factors Associated with Bank Service Supply}

What explains banks' decisions to locate their services in some municipalities rather than others? Attempts were undertaken to associate three different supply side measures of access to banking services (first, the presence or absence of a bank branch; second, branches per million inhabitants; and third, credits or deposits as a ratio of GDP) with economic characteristics (income per capita and regional GDP) as well as locational characteristics: population density, shares of rural and agricultural population, and the share of small firms to GDP (Table 6). ${ }^{13}$

For all measures of access used here, except the existence of a bank branch, per capita income was positively associated with access. That is, banks try to locate in regions where people are better off. ${ }^{14}$ Municipalities with higher overall GDP also tend to have better

Table 6. Brazil-What Explains Bank Branch Services across Municipalities? (All Banks)

\begin{tabular}{lcccc}
\hline $\begin{array}{l}\text { Dependent } \\
\text { variable }\end{array}$ & $\begin{array}{c}\text { 1. Existence } \\
\text { of branch }\end{array}$ & $\begin{array}{c}\text { 2. Branch } \\
\text { density }\end{array}$ & $\begin{array}{c}\text { 3. Credit/ } \\
\text { GDP }\end{array}$ & $\begin{array}{c}\text { 4. Deposits/ } \\
\text { GDP }\end{array}$ \\
\hline Econometric model & Probit & Tobit & Tobit & Tobit \\
\hline Income/capita (R\$'000) & $-0.05(0.00)$ & $12.16(0.00)$ & $0.18(0.23)$ & $0.16(0.13)$ \\
GDP(R\$ million) & $0.04(0.00)$ & $-0.00(0.24)$ & $0.00(0.03)$ & $0.00(0.13)$ \\
Population density & $-0.00(0.00)$ & $-0.02(0.00)$ & $-0.00(0.78)$ & $0.00(0.00)$ \\
Rural population & $-0.01(0.00)$ & $-2.06(0.00)$ & $-0.42(0.00)$ & $-0.27(0.00)$ \\
Agricultural share & $0.00(0.93)$ & $0.15(0.52)$ & $0.08(0.16)$ & $-0.03(0.46)$ \\
Small firm share & $0.02(0.00)$ & $1.38(0.00)$ & $-0.01(0.93)$ & $-0.01(0.91)$ \\
No. of observations & 4,958 & 4,958 & 4,958 & 4,958 \\
& & & & \\
\hline
\end{tabular}

Note: Existence of a branch is a dummy variable equal to one if a municipality has a branch and zero otherwise. Branch density is the number of branches per million persons. $P$-values in parentheses indicate significance; $.01>p>0$ indicates significance at the $1 \%$ level.

Sources: IBGE, IPEA, Central Bank of Brazil.

13. Drawing upon data from Appendix Table B.7 and Appendix Table B.8.

14. This may be partly because of policy driven pressures in bank mergers and sales to maintain at least one service outpost in each municipality. 
bank access. ${ }^{15}$ There is also a clear result, across all measures, that areas with lower rural populations are more likely to have a bank branch. These results, indicating urban bias in the provision of bank services, are very significant. However, high population density is negatively associated with branch existence and branch density, suggesting that some more densely populated areas, such as those which are urban and poor are not likely to attract bank services. In contrast with the negative association for rural indicators, the share of work force in agriculture does not show any significant relation with the level of bank services, which may reflect the series of policy incentive schemes offered for agricultural lending. Thus results suggest that while rural areas are indeed underserved, agriculture is not a neglected sector.

Is there any differential in the factors affecting the provision of financial services by private and public banks? (See Table 7.) Using measures of branch density and volumes of services, private banks have a significant positive association with per capita income. However, for branch density, public banks also indicate a significant positive relation with per capita income. Second, in terms of associations with GDP the behavior of public and private banks is similar in many respects; both reflect a generally positive association with GDP. Third, the negative association with population density is similar for the first two measures (Appendix Table B.9 and Appendix Table B.10).

The urban bias of both groups also is similar on all measures. However, on the share of the population in agriculture, for all measures public banks are, surprisingly, negatively associated with the agricultural share, while private banks services are positively associated with this. Measures are significant for branch density and for the share of credit. As discussed for aggregate data, this may reflect directed credit policies in agriculture. Results on small firm shares are positive for private banks, unlike public banks, for the first two measures of access, though not significant for measures related to credits and deposits. There are thus indications that municipalities with a larger share of agriculture and small firms are better served by private banks.

The likelihood that a municipality has a public bank branch is negatively correlated with the existence of a private bank branch, and also the converse. This suggests some substitutability, and is driven by the fact that nearly half of all municipalities with a bank branch have only public or only private bank branches. Public and private banks may compete for services as they operate broadly as substitutes in many areas.

An additional measure to better capture differences between private and public banks is constructed by defining two categories of municipalities, which are served with only private and municipalities with only public bank branches. Results reveal that municipalities with only public bank branches are significantly poorer, in per capita income terms, with average per capita income of $\mathrm{R} \$ 2,771$, compared to $\mathrm{R} \$ 4,060$ for those with only private branches. However, they also have a significantly lower share of agricultural work force3.8 percent compared to 5.1 percent for those with only private branches. They also had fewer small firms. ${ }^{16}$

15. Access measured by branch density is an exception; but here overall association is weak.

16. Significant at the $1 \%$ level using chi-squared tests of differences. 
Table 7. Brazil-What Explains Public versus Private Bank Branch Services across Municipalities?

\begin{tabular}{|c|c|c|c|c|c|}
\hline $\begin{array}{l}\text { Dependent } \\
\text { variable }\end{array}$ & $\begin{array}{l}\text { Existence of } \\
\text { bank branch }\end{array}$ & $\begin{array}{c}\text { Bank branch } \\
\text { density }\end{array}$ & Credit/GDP & $\begin{array}{c}\text { Deposits/ } \\
\text { GDP }\end{array}$ & $\begin{array}{c}\text { Share of public } \\
\text { bank branches } \\
\text { in total branches }\end{array}$ \\
\hline Econometric model & Probit & Tobit & Tobit & Tobit & Tobit \\
\hline \multicolumn{6}{|l|}{ Public Banks } \\
\hline $\begin{array}{l}\text { Income/cap. } \\
\text { (R\$ 000) }\end{array}$ & $-0.10(0.00)$ & $6.81(0.00)$ & $-0.08(0.64)$ & $-0.04(0.72)$ & $-0.03(0.00)$ \\
\hline GDP(R\$ m) & $0.02(0.00)$ & $-0.00(0.31)$ & $0.00(0.98)$ & $0.00(0.33)$ & $0.00(0.98)$ \\
\hline Population density & $-0.00(0.00)$ & $-0.01(0.00)$ & $-0.00(0.07)$ & $0.00(0.65)$ & $0.00(0.69)$ \\
\hline Rural population & $-0.01(0.00)$ & $-1.28(0.00)$ & $-0.45(0.00)$ & $-0.28(0.00)$ & $0.01(0.00)$ \\
\hline Agricultural share & $-0.00(0.30)$ & $-0.43(0.04)$ & $-0.03(0.64)$ & $-0.10(0.04)$ & $-0.01(0.00)$ \\
\hline Small firm share & $0.00(0.46)$ & $-0.60(0.02)$ & $-0.32(0.00)$ & $-0.23(0.00)$ & $-0.00(0.00)$ \\
\hline $\begin{array}{l}\text { Existence of public } \\
\text { bank branch }\end{array}$ & $-0.40(0.00)$ & & & & \\
\hline $\begin{array}{l}\text { Public branch } \\
\text { density }\end{array}$ & & $-0.35(0.00)$ & & & \\
\hline $\begin{array}{l}\text { Credit by public } \\
\text { banks/GDP }\end{array}$ & & & $0.57(0.00)$ & & \\
\hline $\begin{array}{l}\text { Deposits by public } \\
\text { banks/GDP }\end{array}$ & & & & $0.00(0.97)$ & \\
\hline \multicolumn{6}{|l|}{ Private Banks } \\
\hline $\begin{array}{l}\text { Income/cap. } \\
(\mathrm{R} \$ 000)\end{array}$ & $0.00(0.32)$ & $11.11(0.00)$ & $0.16(0.00)$ & $0.16(0.00)$ & \\
\hline $\mathrm{GDP}(\mathrm{R} \$ \mathrm{~m})$ & $0.02(0.00)$ & $-0.00(0.57)$ & $0.00(0.00)$ & $0.00(0.05)$ & \\
\hline Population density & $-0.00(0.00)$ & $-0.02(0.00)$ & $0.00(0.00)$ & $0.00(0.00)$ & \\
\hline Rural population & $-0.02(0.00)$ & $-3.24(0.00)$ & $-0.14(0.00)$ & $-0.13(0.00)$ & \\
\hline Agricultural share & $0.00(0.05)$ & $0.72(0.01)$ & $0.03(0.01)$ & $0.00(0.33)$ & \\
\hline Small firm share & $0.01(0.00)$ & $1.45(0.00)$ & $-0.01(0.66)$ & $-0.01(0.97)$ & \\
\hline $\begin{array}{l}\text { Existence of private } \\
\text { bank branch }\end{array}$ & $-0.48(0.00)$ & & & & \\
\hline $\begin{array}{l}\text { Private branch } \\
\text { density }\end{array}$ & & $-0.36(0.00)$ & & & \\
\hline $\begin{array}{l}\text { Credit by private } \\
\text { banks/GDP }\end{array}$ & & & $0.02(0.00)$ & & \\
\hline $\begin{array}{l}\text { Deposits by private } \\
\text { banks/GDP }\end{array}$ & & & & $0.01(0.13)$ & \\
\hline Observations & 4,958 & 4,958 & 4,958 & 4,958 & 3,508 \\
\hline
\end{tabular}

Note: Existence of a branch is a dummy variable that takes on the value one if a municipality has a branch and zero otherwise. Branch density is the number of branches per million persons. Brasilia is excluded from the regressions. However, the results do not change when including it. P-values are reported in parentheses.

Sources: Central Bank of Brazil, IPEA and IBGE. 


\section{Summary of Evidence from Supply Data on Banks and Financial Institutions}

Overall, the results of this chapter reveal first that despite contractions in bank numbers, aggregate delivery of financial services overall has not declined over the last decade, but has remained largely static. Moreover, there have been some expansions of new service delivery points, and growth of some institutions, including cooperatives and microfinance entities. In terms of international comparisons, Brazil may be underbanked compared to developed countries in terms of bank branches but it has performed at least as well or better than its peers among developing or middle income countries. Spatial inequalities in the delivery of financial services are significant among Brazil's regions and have been persistent over time. But much of this difference arises from regional income differentials.

By some measures public banks may provide more services to the poor, but private banks appear to offer more services to agriculture and to small enterprises. In many respects the behavior of the two is broadly similar; both tend to have a positive association with richer economic areas and both have some urban bias. Especially in thinly served areas, they tend to be substitutable, with either private or public services dominating. 



\section{Users of Financial Services- A Survey of Urban Individuals}

A ggregate measures of the supply of financial services do not provide an answer to the question of who has access. Even if a financial institution exists in a given location, it is not clear without more disaggregated data whom the clients of such an institution are, and what their socio-economic characteristics may be. A survey was therefore launched which aimed at: (i) describing individual's present patterns of access to financial services and potential demand; (ii) exploring perceptions of constraints to access; (iii) examining factors which explain access, and (iv) assessing the role of policy directions adopted over this period in the expansion of access, especially policies which emphasized the importance of public banks and bank branch location. Because an estimated 80 percent of Brazil's population lives in urban areas, the survey focused on 2,000 urban residents in 9 metropolitan areas and 2 cities across 11 states. Interviewees were individuals of 18 or above. ${ }^{17}$ Around 55 percent of the surveyed population was in the two largest cities of São Paulo and Rio de Janeiro; the remainder was distributed across small and medium cities in all geographical regions. The largest share was in the southeast61 percent (São Paulo, Rio de Janeiro and Belo Horizonte)—with another 17 percent

17. The individual rather than the household was chosen due to a combination of reasons; financial characteristics are not common to all household members, there are variations across the age spectrum in terms of financial access as well as financial needs. Some questions especially those relating to credit depend on individual characteristics. See Kinnon Scott (Grosh, M. \& Glewwe, P., 2000, chapter 21) on the reasons for selecting the individual as the point of data collection. 
in the Northeast. Other regions (Center-West, North, and South) together account for 21 percent. $^{18}$

Access was "unbundled" in the following broad categories: (i) general access to a formal financial institution, (ii) access to savings and deposit services, (iii) access to credit, and, (iv) access to payments services. ${ }^{19}$ Under each category, access is defined in terms of alternative parameters. For example, access to a financial institution can refer to whether or not a person has an account with such an institution or has made use of it. It also can be described in terms of physical access - that is, the distance or time taken to reach the financial institution used. The socio-economic characteristics of the surveyed population are summarized in the box below. The analysis of findings is discussed in three stages. First, a review of frequencies of responses; second, a correlation of these responses with socioeconomic characteristics of respondents and third, an econometric analysis of factors explaining access and their relative importance.

\section{Survey Results-Access to Financial Institutions}

Among the interesting results to emerge from the survey of frequencies were the following. First of all, 43 percent of individuals interviewed had a bank account, ${ }^{20}$ which itself appears high, but a much larger number of persons made use of formal financial institutions (Table 8). This is because of payment outlets, where it is not necessary to be an account holder to use certain services. Such services have been dominated by the Casa Lotérica or lottery shop chain of the publicly owned giant, Caixa Econômia Federal, although other banks are now beginning to enter into correspondent banking. For almost half the respondents ( 47 percent), these correspondent outlets are deemed to be the most important financial institution. Aside from the lotéricas, the majority of respondents (58 percent) for whom banks were the primary financial institution use private banks. The use of non-bank financial institutions such as cooperatives/credit unions or microfinance was very limited (4 percent of responses).

Is physical distance a barrier to access? Results suggest that branch density is not an important issue. More than a third of respondents ( 37 percent) took less than 10 minutes to arrive at their financial institution and almost three-quarters (73.5 percent) took less than 20 minutes. The relative unimportance of distance may however be a reflection of the urban nature of the survey.

18. The cities are: Goiânia, Brasília, Porto Alegre, Curitiba, São Paulo, Rio de Janeiro, Belo Horizonte, Salvador, Recife, Fortaleza and Belém. The selection is based on the periodic consumer expenditure surveys (POF) of IBGE, Brazil's statistical institute, which uses the Census 2000 results for the distribution of population by city. The advantage was that a ready made existing sampling frame was available and known to be representative. The sample was constructed on a probabilistic basis for census sectors and for domiciles within the sector.

19. Other forms of 'unbundling' could be used. For example, the typology used in a recent study, conducted by the National Community Investment Fund (NCIF) in the USA (2002; "Innovative Products and Services for Low-Income and Unbanked Customers") distinguishes between 'first-order' or prior needs to help financial access (adequate income and minimal financial literacy); immediate financial needs, including liquidity, money orders and bill payments, remittances (wire transfers), short-term credit during emergencies; and long-term financial needs, including savings, access to borrowing, home ownership, insurance and investment.

20. This statistic is surprisingly close to estimates made by Unibanco, one of Brazil's prominent banks, which estimated the 'banked' at 42.8 percent (Unibanco February 2003). The figure is also plausible in view of aggregate statistics on bank accounts in Brazil which amount to at least a third of the population. 


\section{Brazil Financial Access Urban Survey-Socio-economic Characteristics of Respondents}

Despite the exclusion of persons below 18, respondents were relatively young; 60 percent of individuals were below 30 years of age. Education levels were low, with 41 percent below secondary school and only 7 percent with higher education. More than half the individuals began to work by age 15 . Forty three percent left home by age 20 and around half were married by age 25 . Forty three percent were married and 34 percent were single.

Income was not high. The mean income of $R \$ 696.63$ and median income of $R \$ 358.50$ are only 3.5 times and 1.8 times greater, respectively, than the minimum wage. Only 51 percent of the respondents had a job in the last month. Almost two-thirds of these had a full time job. Around two-thirds of the respondents have wages as their primary source of income, 15.4 percent have pensions or social security as their primary source of income. Most of the respondents queried about their role at the work place were employees (597 persons or 60 percent of respondents), and a third were self-employed and 4 percent were employers. Around 400 persons claimed to have a work certificate compared to around 600 who did not. Eleven percent of the sample had never worked.

Household size was not large. More than one third of respondents belonged to a household of less than three persons, 41 percent belonged to households consisting of three to five persons and only 21 percent belonged to households of five or more persons. Around 40 percent of persons interviewed were heads of households and another 43 percent were spouses or children. Over 40 percent of individuals interviewed had no dependents and 25 percent had more than three dependents.

Housing is relatively ample. Only a fifth (19 percent) admitted to living in illegal areas; 83 percent lived in a house or apartment. The majority of the respondents lived in a house with more than one room per person. More than two-thirds of the individuals (or their households) owned their dwelling (70 percent), and less than 20 percent lived in rented homes. Yet, more than half (56 percent) claimed to have dwellings valued at $\mathrm{R} \$ 30,000$ or less. More than one fifth (21.5 percent) have dwellings valued at $\mathrm{R} \$ 10,000$ or less. Less than 5 percent of individuals had dwellings valued at more than $\mathrm{R} \$ 100,000$. Around one third of the individuals lived less than $5 \mathrm{~km}$ from basic services such as a bus stop, a post office, or a public/community telephone. Most persons had a TV (96 percent). Few owned an automobile (33.4 percent) and fewer still owned a computer (14 percent).

Table 8. Indicator of Access: Access to Financial Institutions

\begin{tabular}{lrr}
\hline & Frequency & Frequency (\%) \\
\hline Respondents who: & & \\
Have a bank account & 854 & 43 \\
Use banks as their primary financial institution ${ }^{1}$ & 887 & 46 \\
Use mainly private banks & 515 & 58 \\
Use mainly public banks & 372 & 42 \\
Use CEF lottery shops as their primary financial institution & 909 & 47 \\
Use mainly non-bank financial institutions ${ }^{2}$ & 67 & 53 \\
Are able to reach the financial institution they use on foot & 1014 & 53 \\
\end{tabular}

Notes: ${ }^{1}$ This could include family members of account holders who do not hold accounts themselves.

Includes Credit cooperatives, micro finance institutions, and others.

Source: World Bank, Survey of Access to Financial Services in Urban Areas of Brazil, 2002. 
Around two thirds (64 percent) of those who did not have an account indicated an interest in having one. However, this does not indicate effective demand for bank services, as in many cases, persons may be ineligible for an account, due to risk characteristics or otherwise unlikely to get an account due to bureaucratic requirements, bias or other factors. Possible reasons for not having an account were investigated in two broad categories, voluntary factors (referred to as 'difficulties due to banks') and involuntary factors ('difficulties due to respondent characteristics'). Among the voluntary factors, high fees dominatebank services are expensive for many persons. In parallel, individuals cited that their lack of funds led to a lack of interest. Factors such as lack of documentation, references and difficulties in opening an account suggest that bureaucratic requirements are also important.

A surprisingly large number of persons had had an account and then closed it (629 cases). These suggest difficulties related to the costs of banking services, especially for small accounts. The main reason cited for cancellation was the difficulty of maintaining a minimum balance ( 218 cases) combined with cancellation by the bank (also due largely to problems in maintaining the minimum balance) and high fees. These three factors combined amounted to 54 percent of responses. ${ }^{21}$

\section{Survey Results-Deposits and Savings Behavior}

Less than 2 percent of respondents put money in term deposits/certificates of deposit, and less than 1 percent bought or sold shares. Less than 4 percent used rotating savings schemes (consortia). Around 10 percent made 'other' investments. (ii) Over half of respondents (54 percent) had their largest deposits in private institutions; 41 percent used public institutions. (iii) Other financial institutions, including cooperatives, accounted for less than 2 percent of responses (Figure 5).

Figure 5. Deposit and Saving Behavior-Survey of Urban Individuals
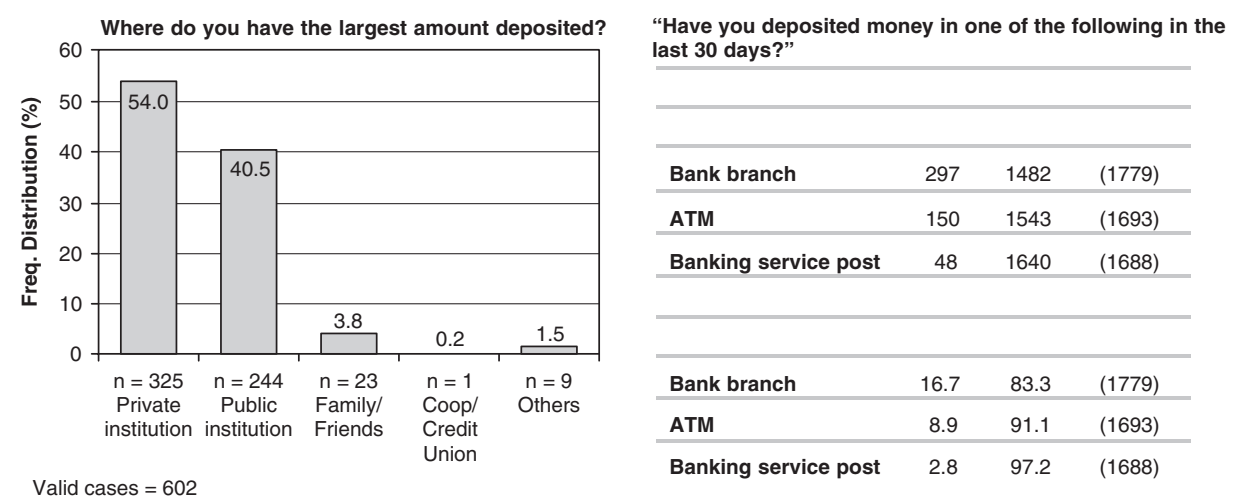

Source: World Bank, Survey of Access to Financial Services in Urban Areas of Brazil, 2002.

21. Discussed in greater detail in Part 3 of this study. Around 40 percent of respondents cited 'other' reasons for not having accounts. 
The most important reason for making deposits was overwhelmingly 'security', for current accounts ( 215 out of 305 valid cases); special savings accounts ( 259 out of 354 valid responses), and also, surprisingly, for term deposits. Other reasons were access to other financial services (30 out of 305 cases). Rates of return appeared only third in order of importance, suggesting a weak association between deposit services and interest rates. Moreover, withdrawals were not typically associated with diminishing returns or increased risk but for liquidity needs (92 percent). (v) Accounts often have limited services; only 61 percent of account holders had checking facilities. (vi) Other forms of savings and investments, in non-bank assets, were low. Only 147 persons made voluntary contributions to pension funds ( 7.5 percent of respondents), and most were public ( 71 percent).

\section{Survey Results—Loans and Credit Services}

Only 15 percent of respondents had applied for credit in the past 12 months, and only twothirds of applications were accepted. The use of guarantees or collateral in successful applications was surprisingly low; only 12 percent ( 24 persons out of 194 successful loan applicants). These largely took the form of personal guarantees, followed by business inventories, bank accounts and institutional guarantees. A third of respondents used private institutions as their primary source of credit, while a quarter (26 percent) used public institutions and a similar proportion (24 percent) used family and friends. Finance companies accounted for nearly 10 percent, while credit unions and shops only provided for loans to for 1.5 percent of creditors respectively. The reported incidence of pawnbrokers was surprisingly low; only 1 percent of accepted loans.

In terms of uses of credit, the majority of the respondents applied for a loan for personal purposes (160 persons or 83 percent of respondents). Only 14 borrowers ( 7.3 percent of respondents) cited business reasons. The largest single use of loans (69 cases or 44 percent of respondents) was for family emergencies. Another 15 percent of respondents used the loan to purchase or renovate their homes, and a slightly smaller proportion, 13 percent used the loan for buying household goods. ${ }^{22}$ Unexpectedly, loans for automobile purchase were very low (only 3 percent, perhaps because of the practice of leasing), and loans for education are also low, suggesting limited borrowing on a 'life cycle' basis. However borrowing to smooth unexpected consumption needs appears to be common. Among business financing needs, working capital predominated in the small number of responses ( 6 cases out of 12) although payments to creditors ( 2 cases), routine maintenance and unforeseen business needs were also cited (1 case each). When not using formal credit, almost half of the respondents ( 49 percent) took loans from family and friends ( 35 percent from families and 14 percent from friends). And 15 percent of respondents had made a loan to their families in the last 12 months.

Average loan amounts were low; 50 percent of respondents applied for $\mathrm{R} \$ 500$ or less; 74 percent applied for loan amounts of $\mathrm{R} \$ 1,000$ or less. Amounts approved very closely follow amounts requested, suggesting that in cases of doubtful applicants, credit is rationed

22. At a different point in the questionnaire, it was asked how real estate had been financed. The response was that only 37 percent of respondents used a financial institution to obtain a loan for real estate purchase and renovation. 
by screening out the applicant, rather than by reducing the volume of credit extended. On the status of loans received in the last 12 months, a quarter were paid off, suggesting short maturities. ${ }^{23}$ Over 62 percent claimed to be up to date on loan servicing, while around 12 percent of respondents admitted to some late payments or to a renegotiation of the loan. Loan processing is surprisingly rapid-more than half claimed to receive a response regarding their loan application on the same day (58 percent), another 26 percent between $1-5$ days.

Additionally, around a quarter of persons had access to a debit card and a fifth had a credit card. (Table 9). Of these, more than half of respondents (58 percent) had credit card limits of $\mathrm{R} \$ 600$ or less (this is around twice the mean monthly income). Forty four percent of respondents had credit card debts of $\mathrm{R} \$ 200$ or less outstanding; another 42 percent had credit card debts between $\mathrm{R} \$ 200-\mathrm{R} \$ 600$.

Does the low proportion of applicants for credit (only 15 percent) point towards low probabilities of obtaining credit or low credit needs? Most respondents who did not reply for a loan (70 percent) claimed that they did not need the money. However, 17 percent responded that they assumed the response would be negative. The balance did not know how to apply (4 percent), or had other reasons (13 percent).

Table 9. Access to Loans and Credits

\begin{tabular}{lcc}
\hline & Frequency & Frequency(\%) \\
\hline Respondents who: & 205 & 10 \\
Applied for a loan and received it & 95 & 5 \\
Applied for a loan but did not receive it & 1679 & 85 \\
Did not apply for loans & & \\
Received credit primarily from: & 68 & 33 \\
Private institutions & 52 & 25 \\
Public & 49 & 24 \\
Family/Friends & 20 & 10 \\
Finance companies & 3 & 2 \\
Credit cooperatives or credit unions & 3 & 2 \\
Commercial shops & 9 & 4 \\
Others & 14 & 8 \\
Received a business loan & 160 & 92 \\
Received a personal loan & 170 & 88 \\
Did not require collateral to obtain the loan & 96 & 37 \\
Used a financial institution to obtain a loan for real estate & 503 & 26 \\
Had a debit card & 392 & 20 \\
Had a credit card & & \\
\hline
\end{tabular}

Source: World Bank, Survey of Access to Financial Services in Urban Areas of Brazil, 2002.

23. Information on loan maturity suggests that 78 percent of loans were for a period of 12 months or less and 20 percent were for less than one month. Interest rates on a monthly basis averaged 85 percent. 
Table 10. Access to Loans and Credits-Reasons for Loan Refusals

\begin{tabular}{|c|c|c|c|c|c|c|}
\hline & \multicolumn{2}{|c|}{ Primary Reason } & \multicolumn{2}{|c|}{ Secondary Reason } & \multicolumn{2}{|c|}{ Tertiary Reason } \\
\hline & Frequency & (\%) & Frequency & (\%) & Frequency & $(\%)$ \\
\hline Didn't have a steady income & 2 & 22.2 & 3 & 60 & - & \\
\hline Didn't have any guarantees & 2 & 22.2 & 1 & 20 & 3 & 42.9 \\
\hline Didn't have enough earnings & 2 & 22.2 & 1 & 20 & 1 & 14.3 \\
\hline Didn't have a job & 1 & 11.1 & - & - & 1 & 14.3 \\
\hline Returns less than expenses & 1 & 11.1 & - & - & 1 & 14.3 \\
\hline Others & 1 & 11.1 & - & - & 1 & 14.3 \\
\hline Valid cases & (9) & & (5) & & (7) & \\
\hline
\end{tabular}

Source: World Bank, Survey of Access to Financial Services in Urban Areas of Brazil, 2002.

Second, what reasons were offered to those who had applied for credit but had been refused? Respondents with loan application rejected cited not having a steady income, not having any guarantees and not having enough earnings as the primary reasons (Table 10). However, the responses to this question were limited in number and these results can only be considered suggestive.

\section{Survey Results-Payments and Money Transmission Services}

Cash was overwhelmingly the standard medium of payment for all types of transactions and respondents; 77 percent used cash for all transactions. Even for categories such as education, health and house rent or mortgage payments; the proportion of cash is very high, at 87 percent, 85 percent, and 88 percent respectively. More, surprisingly, 92 percent of utility bills are paid in cash. The only expenditure categories where cash use is lower is consumer durables: 77 percent for electro-domestic goods and 80 percent for furniture. This could reflect credit offered by consumer finance companies, especially, post-dated checks - in these two payment categories, payment amounted to 12 percent and 13 percent respectively. Additionally credit cards are also used in these two categories, by 9 percent and 6 percent of respondents, respectively. Credit cards or debit cards are used for daily purchases by only 7 percent of the persons surveyed, though debit cards are also used for utility payments by around 5 percent of persons.

In terms of points of payment, a surprisingly high proportion (over 90 percent) make payments in person at bank branches (54 percent) or other points (38 percent); only 2.5 percent use the mail (44 persons) and just over 1 percent use the internet or telephone. These numbers suggest that retail payments systems are still unsophisticated for the majority of persons. Are the present retail payments systems burdensome? Surprisingly, despite the high proportion of cash payments, between 30 and 40 percent of respondents claimed that payments for utilities, education and health could be made in less than ten minutes, and for 50-60 percent of respondents, less than 20 minutes. Yet, for 15-22 percent of the persons, these payments take from half an hour to an hour. 
Payments services were also investigated in terms of income receipt. More than twothirds of respondents ( 68 percent) received their primary income in cash, while 24 percent had direct deposits in their bank accounts. Only 4 percent receive checks. Cash preference is high; the proportion of persons who would like to receive cash payments (72 percent) is even higher than those who actually receive cash. Checks appear to have the greatest disutility as the proportion who would like to be paid by check ( 91.5 percent) is lower than the actual proportion. ${ }^{24}$ The great majority ( 72 percent) would like to receive their incomes in cash, followed by deposits in bank accounts (24 percent). Check cashing is usually at a public institution (50 percent); only 26 percent is at private institutions. Eleven percent of respondents use family or friends and nine percent use a commercial shop. It is interesting that although there is a preference for private institutions for overall banking services and also for deposit services, preferences are reversed for check cashing. This may indicated that private banks services for check cashing are more onerous or more expensive. Finally, remittances are rare-only 68 persons or 3.5 percent of respondents had sent or received remittances in the last year. Around two fifths of these were by interbank transfer and another ten percent through the postal system. Another two fifths were in cash or through personal transmission. 
CHAPTER 4

\section{Analysis of Survey Results- What Explains Access?}

$\mathrm{N}$ ext we analyzed the association between different measures of access and selected economic parameters through the construction of cross-frequencies, and then through regression analysis, to examine policy or behavioral explanations for observed differentials in access. ${ }^{25}$ Measures of financial access used followed the same four broad categories described above; use of a formal financial institution, access to deposit and savings facilities, access to loans and credits, and finally, access to payments services.

Particular attention was paid to three specific issues. The first was location and the association between the location of the respondents and the availability of financial services. Locational measures of access have been the primary means through which the government has tried to track and to address shortcomings in access. A central feature of government policies for the expansion of access has been the attempt to put some financial institution or point of service in each municipality. However, location can be interpreted at two levels; first the region of the country; and second, the microeconomic characteristics of the neighborhood and dwelling of the respondent. It is proposed here that there may be significant micro differences in "location" within a region, state or even municipality, which could have pockets of poverty within broadly prosperous areas - and conversely, could have wellto-do persons even in municipalities which are less affluent. We explore the association between access and both definitions of location.

25. Differences in the distributions of variables between the parameters examined (different regions, different institutions, different socioeconomic categories, etc.) are tested for significance using chi-squared tests of independence. Significant statistics reported here, unless noted, are significant at a 1 percent level. Detailed results are available in background papers. Results presented here are summaries only; more detailed background papers are available. 
Second, we looked at the role of different types of financial institutions in the provision of financial services. Many governments assume that due to market failures in financial markets, there is a need for a public role in the provision of financial services, and hence that public banks have a special role to play. As shown in Chapter 2, public banks and private banks often behave in similar ways and are broadly substitutable in services to some segments of the population. We tried to further investigate the role of public financial institutions, to see if they better served the poorer segments of society.

Third, we paid special attention to the role of information in the provision of financial services. It has been pointed out that one of the key reasons for the limited access to financial services to the poor is the huge difficulty in gathering information on such persons - the asymmetric information problem. We therefore investigated the extent to which proxies for information on creditworthiness, such as income, wealth or the possession of collateral, could influence decisions regarding the provision of financial services. If there were significant asymmetries in the availability of information, these would be illustrated by the importance of such proxy variables for creditworthiness. The policy implication would be to improve overall information on creditworthiness and also to address the specific biases noted.

\section{The Impact of Location on Financial Access-Regions of the Country}

There is a clear variation in a series of indicators of financial access across regions, which broadly indicate that the poorer North, and sometimes the Northeast of the country are more limited in access than the more affluent central or southern regions (Figure 6 and Appendix Table B.11). ${ }^{26}$ Almost three-fourths of respondents in the North (75 percent) and in the Northeast (71 percent) did not have a bank account; in contrast around half of the persons in the South ( 55 percent) and Southeast ( 45 percent) did. Only 6 percent of the respondents who lived in the North had deposits in contrast to more than one-third of individuals who lived in South (37.5 percent). Further, 97 percent of persons in the North did not apply for loans, compared to 83 percent in the Southeast. Regarding payments, only 18 percent of persons in the Northeast and 16 percent of persons in the North had a debit card, in contrast to 40 percent in the South and 44 percent in the center. ${ }^{27}$ Only 2 percent of respondents that lived in the North used transfers or direct deposits to made payments in contrast to 15 percent of individuals in the Southeast.

\section{Location in Terms of Micro Regions-Neighborhoods and Areas within a City}

Differences in access can be strong within a region, at the level of individual neighborhoods (Appendix Table B.12). Distinguishing between persons living in legalized areas and those in illegal areas, we found that 45 percent of the former were bank account holders in contrast

26. Differences cited in this chapter are all based on the results of chi-squared tests of independence of distributions (see Appendix 1.2: Technical Note on Estimation) and are significant at the 1 percent or 5 percent levels. Results with the corresponding test statistics are detailed in Appendix Table B.16 to Appendix Table B.15) .

27. For credit cards, there are also differences in proportions, which are significant but weaker. 


\section{Figure 6. Role of Location in Financial Access}
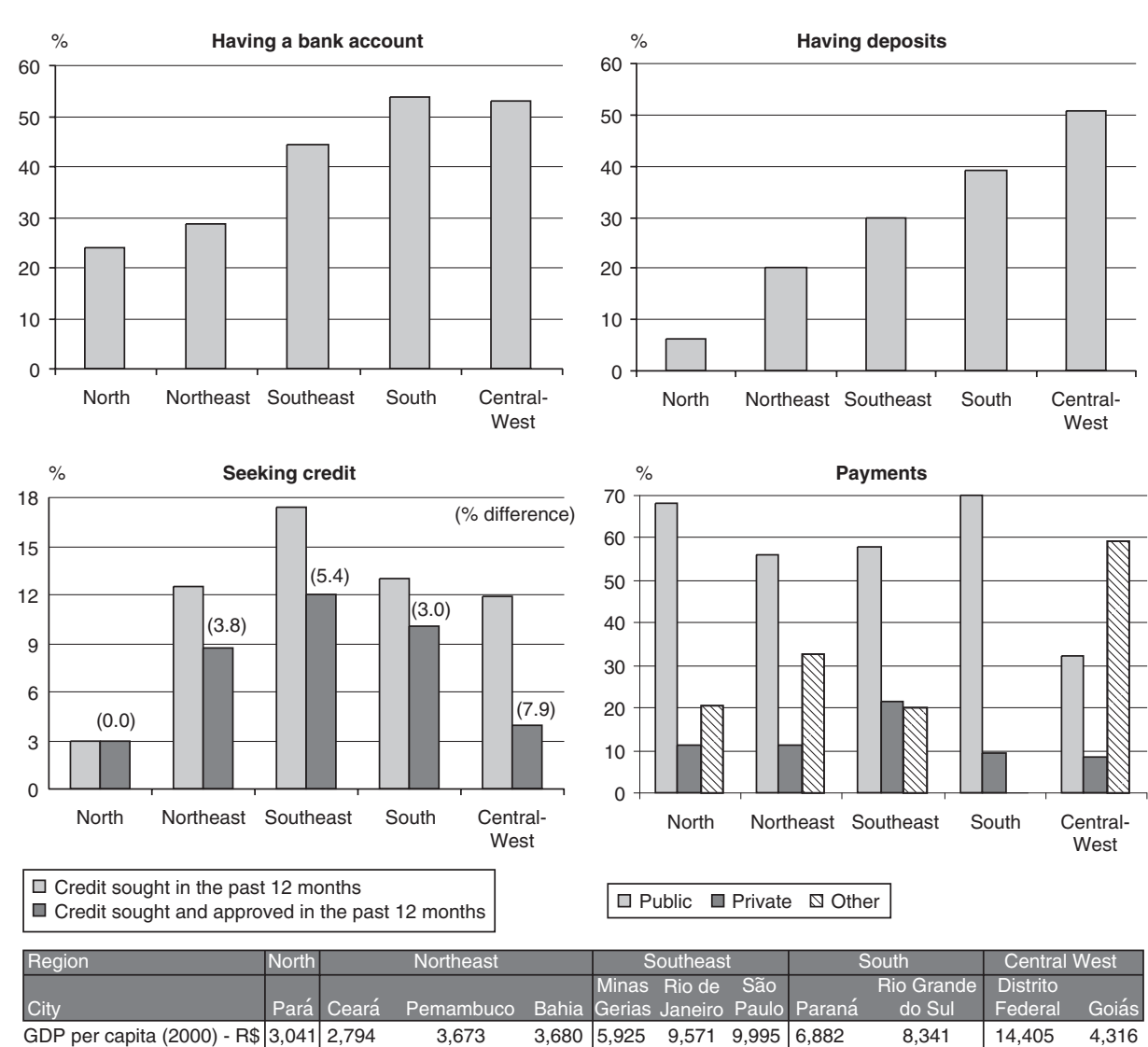

Source: World Bank, Survey of Access to Financial Services in Urban Areas of Brazil, 2002. GDP data provided by IBGE.

to only 37 percent of persons in the latter. Similarly with regard to type of building, only 34 percent of people who lived in informally constructed shacks or in rooms had a bank account, in contrast to almost half ( 45 percent) the persons who lived in regularized houses or apartments. Further, only 13 percent of individuals with houses of less than 0.5 rooms per person had accounts, compared to more than half the individuals who lived in houses of more than 2 rooms per person. More than half the respondents (59 percent) who lived in shacks or rooms used mainly correspondent banks, 47 percent of persons who lived in house or apartment used mainly bank institutions. Similar patterns emerged in terms of numbers of rooms per person in a home. Almost two-thirds (56 percent) of individuals who lived in houses with more than two rooms per person used banks, while more than twothirds of respondents who lived in houses with less than 0.5 rooms per person (64 percent) used correspondents.

Results were similar when we analyzed access to deposit facilities: 30 percent of individuals who lived in a unique permanent house had deposit balances compared to only 19 percent 
of individuals who lived in collective dwellings. ${ }^{28}$ Forty-one percent of the individuals who lived in a house with more than two rooms per person had deposit balances, in contrast to only 7 percent of persons who lived in a house with less than 0.5 rooms per person. Looking at credits, 83 percent of respondents living in homes with more than two rooms per person did not apply for loans, compared to 94 percent of people who lived in houses with less than 0.5 rooms per person. Thirty-four percent of persons who lived in a house with more than two rooms per person had a debit card, while only 5 percent of persons who lived in homes with less than 0.5 rooms per person had a debit card. Differences in proportions for credit cards were also significant. Finally, persons who used cash for payments were higher in illegal areas (84 percent) than in legalized areas (75 percent). Observations were similar when we compared respondents who lived in houses and apartments with respondents who lived in shacks or rooms.

This suggests that although there are indeed differences between the availability of financial services between regions of the country, placing financial institutions in each region or municipality in itself is not a sufficient condition for broadening access. There may well be important differences also within neighborhoods and districts of a municipality, region or state. Even if there is a financial institution present in a given location, its clients may be biased towards the better off persons. Conversely, areas benefiting from dense networks of financial institutions may still have pockets of the underserved.

\section{The Role of Public and Private Institutions and Financial Access}

Brazil's public banks have been considered important vehicles of outreach to underserved communities, and this role has been premised upon market failures or imperfections which make it too costly or too risky for private banks to lend to some communities. Investigating the differences in outcomes for public and private banks in terms of the provision of various forms of financial services, and between groups of persons with different socioeconomic characteristics, our overall finding was that there are some significant associations where relatively disadvantaged groups make greater use of public bank facilities (those in poorer regions versus those in more affluent regions; those in poorer neighborhoods or homes compared to those in more affluent neighborhoods or better homes and those with higher income or education compared to those with lower income or education). However, there are many instances where there are no clear associations of the less well off with public banks, or even the reverse. Disaggregating by type of service, individuals' use of public and private banks depends considerably on the type of financial service sought, and on how public banks are defined. The importance of the correspondent network of one large public bank, the Caixa Economica Federal, is critical. If we include the use of its correspondent outlets (which does not require the holding of an account), the role of public banks increases considerably.

28. Defined in this question as money in either a special savings account, a current account or a term deposit account. A generic definition of deposits yielded similar results; 52 percent of persons living in a house with more than 2 rooms per person had no deposits; in contrast, 90 percent of people in homes with less than 0.5 rooms per person had no deposits. 
Looking at poorer versus wealthier regions, including correspondents, 84 percent of individuals in the North used mainly public banks, compared to around two-thirds of individuals in the Southeast. Without Caixa correspondents (the lottery shops), the difference diminishes but remains significant-half the persons in the North continue to use public banks, but in the southeast users of public banks falls to around 38 percent (Appendix Table B.13). Similarly, looking at "micro regions" and including correspondents, 81 percent of persons in homes of less than 0.5 rooms per person used mainly public banks compared to 61 percent of individuals in houses of over 2 rooms per person. With a narrower definition, excluding the use of correspondent outlets, 48 percent of those with less than 0.5 rooms per person used public banks, compared to 36 percent of those with more than two rooms per person. However, both differences are significant (Appendix Table B.14). Thus public banks have helped to serve those in less-well-off regions as well as in less-well-to-do neighborhoods.

In terms of income, 36 percent of persons with income in the highest quintile used public banks as opposed to 49 percent of individuals in the lowest quintile. With the wider definition, use in both groups goes up, to almost half in the top quintile (51 percent) and 78 percent in the lowest quintile. Looking at wealth, half the persons without collateral used public banks compared to only 40 percent of those with collateral. On including banking correspondents, the majority of individuals with or without collateral used public banks. Similar results are obtained when we look at education, persons with or without jobs, and men versus women.

With regard to payments services, public bank outlets and the lottery shops are grouped together. Payment services, as may be expected, are dominated by the public sector (defined to include the lottery shops), and this preference is true across social groups. Again, there is a suggestion that public banks may be more oriented towards the underserved; (thus, 62 percent of persons in homes with less than 0.5 rooms per person preferred public banks for payments compared to 55 percent of those with more than two rooms per person; similarly 68 percent of persons in the North used public payment outlets, compared to 34 percent and 58 percent for the Center and Southeast, and perhaps most clearly, 58 percent of persons with less than primary education used public payment outlets while 11 percent used private banks; compared to 41 percent with more than secondary education for public payment outlets and 38 percent for private).

Do the more disadvantaged persons make proportionally greater use of public facilities for deposits? This hypothesis returns mixed results. Persons in the lowest income quintile had marginally more deposits in public banks ( 7 percent public compared to 6 percent private, while persons in the top quintile had 25 percent of their deposits in the public sector compared to 42 percent in the private sector) and persons in the northeast had proportionally more deposits in public banks ( 10 versus 7 percent, compared to 11 percent public and 22 percent private for the southeast), but by contrast, persons living in illegal areas, or persons living in shacks or rooms instead of regular houses or apartments had proportionally more deposits in private banks. Similarly, those in the lower educational levels and those without collateral also made greater use of private compared to public facilities. These results_-all of which are statistically significant differences-are at first surprising in view of the special savings accounts dominated by the Caixa, but can be explained by the high proportion of current accountholders who are offered services at 
private banks. ${ }^{29}$ In terms of credit facilities, the case for public banks is blurred (Appendix Table B.14), and differences in proportions are usually not significant. They suggest that the less privileged have weaker access to both public and private financial services, and there is no general tendency for the disadvantaged to make proportionally greater use of public banks.

The final variable looked at was the use of credit from public versus private banks for home purchase (Appendix Table B.15). With regard to home purchase, the vast majority of the persons in all geographic regions used savings to finance home purchase, however to the extent that bank credit was used, this was used more by the better off states of the south and southeast. Thus, in the North, 70 percent of respondents used savings, 10 percent used credit from public banks and another 10 percent used credit from private banks, while in the Southeast 56 percent used saving, 22 percent used credit from public banks, and 11 percent used credit from private banks. Similarly, looking at micro definitions of location, 13 percent of persons with homes of over two rooms per person used public bank credit, while none of the respondents in homes of less than 0.5 rooms per person did so. Looking at income, almost one half of respondents with low income (49 percent) financed home purchase by savings, 5 percent used credit from public banks and 7 percent used private banks. Again the proportional use of public banks is higher among the high income groups-39 percent of respondents financed home purchase by savings and 18 percent used credit from public institutions. While 12 percent of respondents with a low level of education used credit from public banks to purchase a home, 16 percent of respondents with high levels of education used such institutions. All these results, which are statistically significant, seem to perversely indicate easier access to public bank credit by the more well to do social groups, which may partly reflect superior economic capacity to repay.

To summarize, results from the survey do not indicate that public banks have had a clearly superior role in supporting access. By some measures (looking at overall access to and use of a financial institution), there has been some support for those in poorer regions, and those with lower levels of income and wealth. On disaggregating services, however, it appears that public banks have made the biggest contribution in terms of payment services through the correspondent chains. Their roles in taking deposits and providing credit are less clearly distinguished from private banks, and finally, their role in the provision of housing credit appears perversely to have supported the better off.

\section{The Role of Respondent Characteristics and Financial Access}

As discussed earlier, access can depend on the degree of client information available, because of the impact on risks and hence costs. Obtaining such information can assume special importance in environments where the capacity to enforce repayment may be difficult due to, first, the limited resources of the client, and second, due to the nature of prevailing laws and practice with regard to debt recovery or bankruptcy. In the absence of full information, especially on poorer persons with limited credit histories, institutions tend to look for proxies to information on creditworthiness. Such proxy variables could

29. This is corroborated by an analysis of public and private banks' accounts by size, undertaken in the study 'Brazil—Access to Financial Services' World Bank, February 2004. Part 3. 


\section{Individual Characteristics, Asymmetric Information and Access to Financial Services}

For most measures of financial access, virtually all the socio-economic characteristics included in the analysis turn out to be highly significant discriminators in determining access to financial services. Foremost among these were characteristics referring to income, wealth (possession of collateral) and education. Many variables related to employment characteristics were also highly significant. Finally, for some measures, gender and the position in the household also mattered (see Appendix Table B.16 and Appendix Table B.17).

Income: In terms of access to bank accounts, only 15 percent of persons with income in the lowest quintile had a bank account, in contrast to 64 percent of respondents in the highest quintile. Looking at deposits, only 9 percent of the persons that had income in the lowest quintile had money in either a special savings account, a current account or a term deposit account, in contrast to 47 percent of persons in the top quintile. Using another measure of deposits, 84 percent of persons in the bottom quintile didn't have deposits, in contrast to only 32 percent in the top quintile. Income is also important in determining access to credit and loans. Ninety-two percent of respondents in the bottom quintile didn't apply for credit, compared to 74 percent in the top quintile. Differences in sources of credit however are not very significant among the quintiles of income distribution. Only 5 percent of the persons with a low income had a debit card, in contrast to 40 percent of persons with a high income. Similarly only 7 percent of the persons with a low income had a credit card, compared to 34 percent of persons with a high income.

Education is also a very important determinant in the access to financial institution. Among the significant differences, only 28 percent of persons with education less than primary level had a bank account, while 84 percent of the respondents that had more than secondary school had a bank account. When we compare the access to public and private banks, the majority of respondents with low education used mainly public banks (including the correspondents), while 59 percent of person with high education used mainly private banks (including the correspondents). Only 19 percent of persons with low education had money in a special savings account, a current account, or a term deposit account compared to 64 percent of those with higher education. Only 25 percent of respondents with higher education didn't have deposits, in contrast to 78 percent of those with low education. Ten percent of persons with a low education applied for and received loans compared to 23 percent of respondents with a high education. Only 9 percent of persons with a low education had a credit card, while almost one half of respondents with a high education (48 percent) had a credit card.

Wealth (collateral): Almost one half of respondents that had collateral (45 percent) had a bank account, while only 35 percent of the persons without collateral had a bank account. Collateral is also important for the pattern of deposits and savings, but not as important as income or education. However, possessing collateral is the only characteristic which makes a significant difference to credit sources.

Employment-Having a Job: More than half the people who had a job in the last month (55 percent) had a bank account, in contrast only 30 percent that people who didn't have a job in the last month had a bank account. 38 percent of individuals who had a job in the last month had money in either a special savings account, a current account or a term deposit account, in contrast only 19 percent of persons who didn't. Thirteen percent of respondents that had a job in the last month applied for and received credit, while only 8 percent of persons who didn't have a job were in the same situation. Thirty-four percent of respondents that had a job in the last month had a debit card, in contrast only one half (17 percent) of persons who didn't have a job in the last month had a debit card. The difference is very significant. The same pattern occurs with the possessing of a credit card.

Employment-Having a Work Certificate: 68 percent of employees with a work certificate had a bank account, in contrast to only 44 percent of employees without a work certificate. Forty-seven percent of employees with a work certificate had money in either a special savings account, a current account or a term deposit account, while only 26 percent of employees without a work certificate had money in one of these accounts.

Gender and Position in Household: Half the men had a bank account compared to a third of the women. Half the heads of household had a bank account while only 37 percent of dependents had a bank account. One half of men used banks as the primary financial institution, while 53 percent of the women used correspondents banks. Thirty-four percent of the men had money in either a special savings account, a current account or a term deposit account compared to 23 percent of the women. But gender is not a good determinant for credit and loan behavior. There are also significant differences between women and men in the possession of credit cards and debit cards. 
include information on cash flows (income) which could service loans, or assets (wealth), which could aid loan recovery. It appears that banks also desire such information for opening an account, due to the need to service accounts, or even to accept a deposit. Other characteristics of this form could include position in household (heads versus dependents), gender (males versus females) or employment characteristics.

How important are these factors in obtaining financial services in Brazil? The results cited in the box indicate that information on such characteristics is very important in determining access to financial services. Most important among these characteristics is the income of the respondent, which has a strong positive relation with access to a variety of financial services (Figure 7), including having a bank account, deposit and credit services. ${ }^{30}$ Indeed, in terms of credit, as income levels increase, the proportion of refusals of credit applications diminishes. Simple trend lines fitted to income and credit applications and acceptances tend to converge as incomes rise. Income levels appear to be particularly positively associated with the use of private banks, for deposit and payment services, where their use increases more than proportionately with increases of income, while the use of public banks diminishes.

\section{Figure 7. The Role of Income in Different Measures of Financial Access}

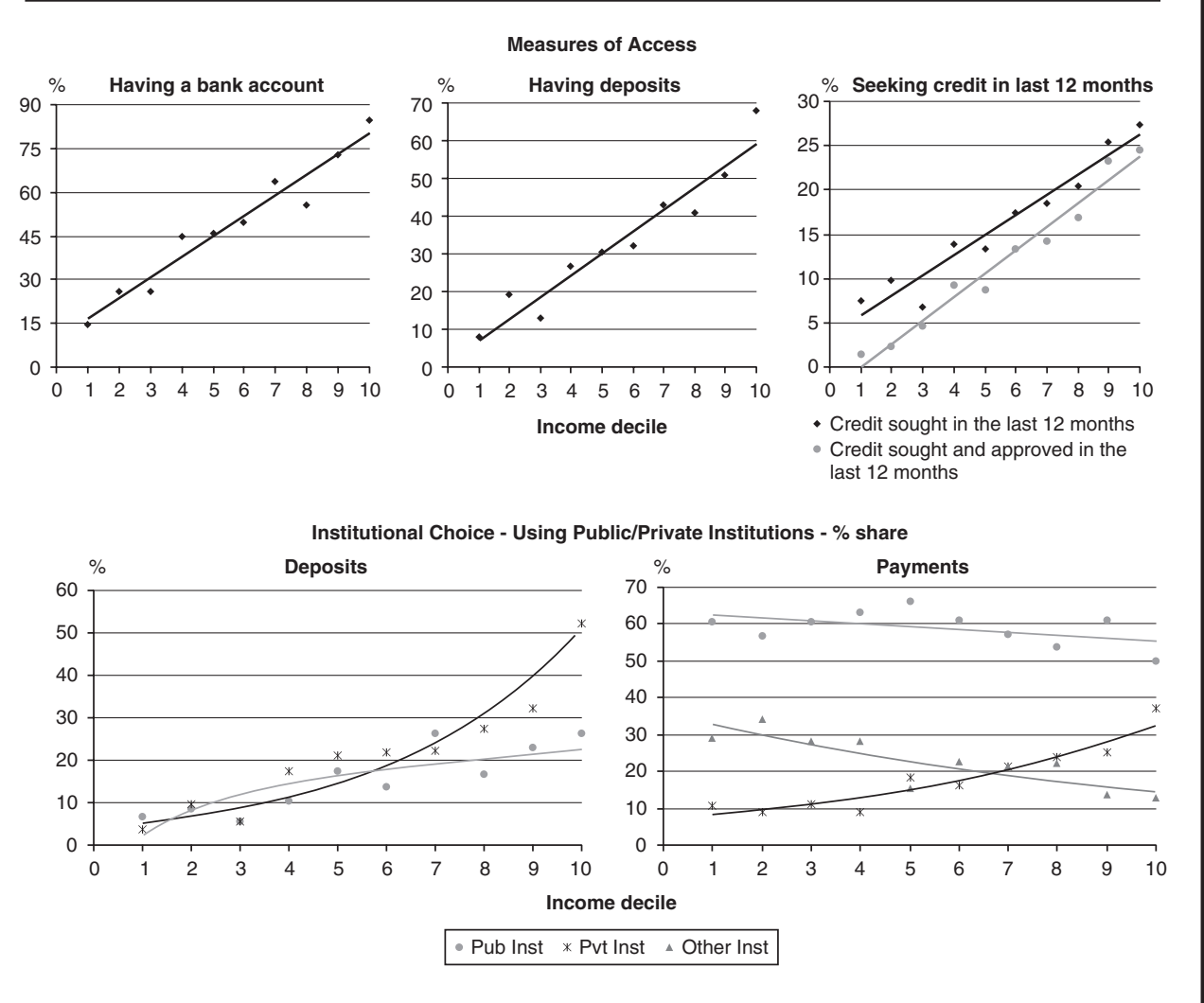

Source: World Bank, Survey of Access to Financial Services in Urban Areas of Brazil, 2002.

30. See Appendix Table B.16 and Appendix Table B.17. 


\section{Determinants of Access-An Econometric Investigation}

In the preceding paragraphs, we examined the extent to which differences in measures of access of different financial services were significant across different socio-economic variables. The final chapter of our analysis was an evaluation of the relative importance of different factors affecting access, based on regression analysis. ${ }^{31}$ The analysis used a series of different measures of access and a range of different explanatory variables related to location as well as individual characteristics, the most significant result to emerge was the importance of income and education as determinants of access (Figure 7). Geographical measures in terms of regions of the country are also significant, especially for determining the institutions used for holding deposits, and similarly, 'neighborhood' characteristics or locality are also important.

Thus for example, using the probability of having a bank account as our measure of access, geographic region of the country, type of building and number of rooms per person (which are measures of the population density of the neighborhood, and hence, indirectly, neighborhood wealth or poverty), income and education level are all significant. If we use a slightly different measure and instead examine the probability of using banks as the primary financial institution, the socio-economic characteristics of income and education remain significant but the importance of geographic location and even dwelling characteristics disappears.

Broadly similar results are obtained when we look at access to specific services. In case of credit services, income is the only independent variable that is related in a significant way with the probability of applying for loans (Table 11). Income and education are both very important for predicting the probability of having either a debit card or credit card. Looking at savings and deposit services, probabilities are significantly linked to income level, education, and parameters of micro location (Table 12). Geographic region is not significant.

Looking at marginal effects, in terms of overall access to financial institutions (Table 11), moving up from the bottom to the second quintile of income increases the probability of having a bank account by 11 percentage points, and increases the probability of using a bank (compared to a non-bank) as a primary financial institution by 62 percent. Persons educated beyond primary level almost double their probability of having a bank account compared to those without any formal education (a 97 percentage points increase in probability), and raises the probability of using a bank (compared to a non-bank) by 41 percent. Distinguishing between public and private banks, it is interesting that additional income lowers the probability of using public banks by 6 percentage points as compared to private banks; additional education lowers the probability of using public banks by 5 percentage points.

Marginal effects for regional differentials show that individuals in the North have a 29 percent higher probability of using a bank compared to those than those living in the Northeast region. However there is evidence of substitution as those in the Northeast have almost twice the likelihood of banking with other institutions as those in the North. ${ }^{32}$

31. The estimation approach used is detailed in Appendix A.

32. This may reflect successful microcredit programs in the Northeast such as the large scale CrediAmigo program. 
Table 11. Econometric Results: Determinants of Access to Financial Services, Select Results

\begin{tabular}{|c|c|c|c|c|c|c|c|}
\hline \multirow{4}{*}{$\begin{array}{l}\text { Dependent variable } \\
\text { Econometric model } \\
\end{array}$} & \multicolumn{4}{|c|}{ Institutional Access } & \multicolumn{3}{|c|}{ Loans and Credits } \\
\hline & \multirow{3}{*}{$\begin{array}{c}\begin{array}{c}\text { Having a Bank } \\
\text { account }\end{array} \\
\text { Probit }\end{array}$} & \multicolumn{3}{|c|}{ Primary Financial Institution } & \multirow{3}{*}{$\begin{array}{l}\text { Applying } \\
\text { for loans }\end{array}$} & \multirow{3}{*}{$\begin{array}{c}\begin{array}{c}\text { Having a } \\
\text { debit card }\end{array} \\
\text { Probit }\end{array}$} & \multirow{3}{*}{$\begin{array}{l}\text { Having a } \\
\text { credit card }\end{array}$} \\
\hline & & Banks & Correspond & public banks & & & \\
\hline & & \multicolumn{2}{|c|}{ Multinomial logit } & Probit & & & \\
\hline & $0.04(0.03)$ & $1.29(0.18)$ & $1.18(0.39)$ & $-0.02(0.14)$ & $0.01(0.20)$ & $0.02(0.25)$ & $-0.02(0.15)$ \\
\hline Sex & $-0.05(0.19)$ & $0.76(0.52)$ & $0.99(0.97)$ & $0.05(0.13)$ & & $-0.05(0.09)$ & \\
\hline Age & $0.02(0.35)$ & & & & $0.02(0.08)$ & $0.02(0.35)$ & $0.02(0.17)$ \\
\hline Position in the household & $-0.07(0.10)$ & & & & $0.02(0.40)$ & $0.01(0.72)$ & \\
\hline Illegal vs. legalized area & $-0.03(0.57)$ & & & & & & \\
\hline Type of house ${ }^{1}$ & & & & & $-0.01(0.67)$ & & \\
\hline Type of building² & $-0.11(0.04)$ & $1.12(0.86)$ & $1.22(0.74)$ & $0.07(0.09)$ & & & $0.00(0.93)$ \\
\hline No. of rooms per person ${ }^{3}$ & $-0.05(0.00)$ & $1.04(0.85)$ & $1.16(0.45)$ & $0.02(0.11)$ & $-0.01(0.44)$ & $-0.02(0.06)$ & $0.00(0.80)$ \\
\hline Having a job & $-0.04(0.80)$ & $0.33(0.56)$ & $0.42(0.66)$ & $0.12(0.34)$ & $-0.06(0.20)$ & $0.06(0.54)$ & \\
\hline Role in Workplace & $-0.01(0.62)$ & $1.54(0.18)$ & $1.42(0.27)$ & $-0.02(0.46)$ & & $0.02(0.38)$ & $-0.05(0.39)$ \\
\hline Part time or full time empt. & $0.01(0.79)$ & $0.35(0.07)$ & $0.29(0.03)$ & $-0.04(0.32)$ & & & $0.01(0.64)$ \\
\hline Sector of activity & $-0.01(0.62)$ & $1.36(0.31)$ & $1.37(0.30)$ & $-0.01(0.56)$ & $0.01(0.14)$ & $-0.03(0.01)$ & \\
\hline Income & $0.11(0.00)$ & $1.62(0.00)$ & $1.19(0.27)$ & $-0.06(0.00)$ & $0.04(0.00)$ & $0.09(0.00)$ & $0.08(0.00)$ \\
\hline Education & $0.97(0.00)$ & $1.41(0.02)$ & $1.01(0.94)$ & $-0.05(0.00)$ & & $0.05(0.00)$ & $0.06(0.00)$ \\
\hline Possession of collateral & $-0.03(0.50)$ & $0.89(0.82)$ & $1.05(0.92)$ & $0.01(0.71)$ & $0.01(0.61)$ & $-0.04(0.21)$ & $-0.08(0.01)$ \\
\hline Observations & 1069 & 1067 & & 1037 & 1200 & 1085 & 1251 \\
\hline
\end{tabular}

Note: Type of building correspondent to live in house or apartment or live in a cottage or room and type of house refers to live in unique permanent house, unique improvised house and in collective house. Values in parentheses are $p$-values; and are significant if 0.05 or below.

Source: World Bank, Survey of Access to Financial Services in Urban Areas of Brazil, 2002. 
Table 12. Determinants of Access to Savings and Deposits Facilities

\begin{tabular}{|c|c|c|c|c|c|c|c|c|}
\hline \multirow{3}{*}{$\begin{array}{l}\text { Dependent } \\
\text { variable } \\
\text { Econometric model } \\
\text { Geographic region }\end{array}$} & \multicolumn{2}{|c|}{$\begin{array}{c}\text { or in a term } \\
\text { deposit account }\end{array}$} & $\begin{array}{l}\text { Had deposits } \\
\text { in public sector }\end{array}$ & $\begin{array}{l}\text { eposits } \\
\text { ic sector }\end{array}$ & \multicolumn{2}{|c|}{$\begin{array}{l}\text { Had deposits } \\
\text { in private sector }\end{array}$} & $\begin{array}{l}\text { Had deposits } \\
\text { in other sectors }\end{array}$ & $\begin{array}{l}\text { posits } \\
\text { sectors }\end{array}$ \\
\hline & \multicolumn{2}{|c|}{ Probit } & \multicolumn{6}{|c|}{ Multinomial logit } \\
\hline & 0.02 & $(0.11)$ & 0.3 & $(0.00)$ & 0.2 & $(0.08)$ & -0.6 & $(0.00)$ \\
\hline Sex & -0.08 & $(0.01)$ & -0.6 & $(0.01)$ & -0.4 & $(0.03)$ & -1.3 & $(0.02)$ \\
\hline Age & 0.01 & $(0.46)$ & & & & & & \\
\hline $\begin{array}{l}\text { Position in the } \\
\text { household }\end{array}$ & 0.03 & $(0.36)$ & 0.3 & $(0.21)$ & 0.00 & $(0.99)$ & 1.8 & $(0.01)$ \\
\hline $\begin{array}{l}\text { Illegal area } \\
\text { vs legalized }\end{array}$ & -0.11 & $(0.38)$ & 0.1 & $(0.75)$ & 0.0 & $(0.94)$ & 0.7 & $(0.49)$ \\
\hline Type of house & -0.09 & $(0.01)$ & & & & & & \\
\hline Type of building & -0.04 & $(0.06)$ & -0.1 & $(0.84)$ & -0.20 & $(0.48)$ & -35.5 & $(0.0)$ \\
\hline $\begin{array}{l}\text { Number of rooms } \\
\text { per person }\end{array}$ & 0.18 & $(0.01)$ & -0.1 & $(0.13)$ & -0.2 & $(0.00)$ & -0.5 & $(0.01)$ \\
\hline Having a job & 0.18 & $(0.18)$ & 2.1 & $(0.02)$ & 0.00 & $(0.99)$ & -0.5 & $(0.72)$ \\
\hline Role in Workplace & -0.04 & $(0.05)$ & -0.3 & $(0.04)$ & -0.1 & $(0.32)$ & -0.1 & $(0.71)$ \\
\hline $\begin{array}{l}\text { Part time or full } \\
\text { time employed }\end{array}$ & -0.01 & $(0.72)$ & -0.3 & $(0.25)$ & 0.00 & $(0.93)$ & -0.2 & $(0.69)$ \\
\hline Sector of activity & -0.02 & $(0.29)$ & -0.2 & $(0.10)$ & 0.0 & $(0.94)$ & 0.2 & $(0.27)$ \\
\hline Income & 0.08 & $(0.00)$ & 0.4 & $(0.00)$ & 0.5 & $(0.00)$ & -0.1 & $(0.44)$ \\
\hline Education & 0.08 & $(0.00)$ & 0.4 & $(0.00)$ & 0.4 & $(0.00)$ & 0.00 & $(0.86)$ \\
\hline $\begin{array}{l}\text { Possessing of } \\
\text { collateral }\end{array}$ & 0.01 & $(0.82)$ & 0.1 & $(0.59)$ & 0.0 & $(0.87)$ & -0.2 & $(0.76)$ \\
\hline Observations & \multicolumn{2}{|c|}{1077} & \multicolumn{6}{|c|}{942} \\
\hline
\end{tabular}

Note: Type of building correspondent to live in house or apartment or live in a cottage or room and type of house refers to live in unique permanent house, unique improvised house and in collective house. Values in parentheses are $p$-values; and are significant if 0.05 or below.

Source: World Bank, Survey of Access to Financial Services in Urban Areas of Brazil, 2002.

It is also interesting that gender effects are strong for deposit services. Women have around half the chance ( 0.4 to 0.6 ) of having bank deposits in public or private banks or other institutions, compared to men, after controlling for other factors.

Results for deposit services reveal marginal effects of around 8 percentage points for each of the variables income and higher education. Micro measures of location appear similarly important; those living in improvised or collective houses have 9 percentage points lower likelihood of having deposit balances, and people living in houses with less than two rooms per person have an 18 percent lower probability of having bank deposits. For credit services, additional income and education beyond primary levels are the only significant 
Table 13. Econometric Results: Determinants of Volume of Credit Requested and Approved

\begin{tabular}{lcc}
\hline Dependent variable & Amount requested for loans & Amount approved for loans \\
\hline Econometric model & Linear model & Linear model \\
\hline Age & $-57.43(0.53)$ & $-21.83(0.80)$ \\
Double Age & $16.87(0.35)$ & $5.70(0.74)$ \\
Number of dependents & $17.41(0.73)$ & $63.36(0.18)$ \\
Role in Workplace & $-4.26(0.90)$ & $-21.06(0.51)$ \\
Income & $45.73(0.03)$ & $39.50(0.04)$ \\
Education & $4.28(0.88)$ & $24.47(0.37)$ \\
Possessing of collateral & $-81.41(0.23)$ & $-42.14(0.51)$ \\
Observations & 822 & 822 \\
\hline
\end{tabular}

Source: World Bank, Survey of Access to Financial Services in Urban Areas of Brazil, 2002. Parentheses denote $P$-values and are significant if 0.05 or below.

determinants of credit (loan applications, debit or credit cards). However marginal effects appear low; fulfilling these two criteria increases the probability of getting loans or credit but by less than 10 percentage points.

Volumes of credit requested and approved depend significantly only on income (Figure 7 and Table 13). Variables that are related to the hypothesis that individuals try to smooth consumption along their lives (like age, education and the number of dependents) are not significant. There is thus no confirmation of the permanent income hypothesis in these results which also emphasize the importance of income in explaining demand for and receipt of credit.

\section{Determinants of Institutional Choice-Public versus Private Banks}

The econometric analysis also suggests that income level and education are significant explicators of the probability of using public banks as the primary financial institution, relative to private banks. A high level of income decreases the probability of using mainly public banks as the primary financial institution. These results are true whether a wider or narrower definition of public banks is used (including or excluding correspondent services). Deposit behavior suggests a markedly higher probability (31 percent) of using public banks in the North, compared to private banks or other financial institutions. In terms of credit services, similar to income, possessing collateral appears to lower the probability of using public banks (Table 14). 


\begin{tabular}{|c|c|c|c|c|c|c|c|}
\hline \multirow[b]{2}{*}{ Dependent variable } & \multicolumn{2}{|c|}{ Financial Institution } & \multicolumn{3}{|c|}{ Deposits } & \multicolumn{2}{|c|}{ Credit } \\
\hline & Public banks & Private banks $^{1}$ & Public banks & Private banks & Other & Public banks & Private banks \\
\hline Econometric model & \multicolumn{2}{|c|}{ Probit } & \multicolumn{3}{|c|}{ Multinomial logit } & & \\
\hline Geographic region & $-0.03(0.33)$ & $-0.02(0.14)$ & $1.31(0.00)$ & $1.17(0.08)$ & $0.53(0.00)$ & $0.77(0.26)$ & $1.03(0.90)$ \\
\hline Sex & $0.05(0.29)$ & $0.05(0.13)$ & $0.56(0.01)$ & $0.64(0.03)$ & $0.27(0.02)$ & & \\
\hline Type of building² & $0.08(0.23)$ & & $0.94(0.84)$ & $0.80(0.48)$ & $0.00(0.00)$ & $0.36(0.24)$ & $1.29(0.10)$ \\
\hline Number of rooms per person & $0.02(0.39)$ & & $0.88(0.13)$ & $0.78(0.00)$ & $0.59(0.01)$ & & \\
\hline Having a job & $0.06(0.75)$ & & $8.42(0.02)$ & $1.01(0.99)$ & $0.59(0.72)$ & & \\
\hline Role in Workplace & $-0.03(0.35)$ & & $0.73(0.04)$ & $0.87(0.32)$ & $0.87(0.71)$ & & \\
\hline Part time or full time employed & $0.00(0.97)$ & $0.07(0.09)$ & $0.72(0.25)$ & $0.98(0.93)$ & $0.79(0.69)$ & & \\
\hline Sector of activity & $-0.01(0.73)$ & $0.02(0.11)$ & $0.86(0.10)$ & $1.01(0.94)$ & $1.25(0.27)$ & & \\
\hline Income & $-0.05(0.00)$ & $0.12(0.34)$ & $1.50(0.00)$ & $1.67(0.00)$ & $0.86(0.44)$ & & \\
\hline Education & $-0.01(0.70)$ & $-0.02(0.46)$ & $1.45(0.00)$ & $1.46(0.00)$ & $1.05(0.86)$ & & \\
\hline Possessing of collateral & $0.01(0.93)$ & $-0.04(0.32)$ & $1.15(0.59)$ & $0.96(0.87)$ & $0.83(0.76)$ & $0.28(0.05)$ & $2.07(0.11)$ \\
\hline Age & & $-0.01(0.56)$ & & & & $1.71(0.01)$ & $0.45(0.09)$ \\
\hline Position in the household & & $-0.06(0.00)$ & $1.33(0.21)$ & $1.00(0.99)$ & $6.04(0.01)$ & & \\
\hline Illegal area vs legalized & & $-0.05(0.00)$ & $1.10(0.75)$ & $1.02(0.94)$ & $2.01(0.49)$ & & \\
\hline Type of house ${ }^{3}$ & & $0.01(0.71)$ & & & & & \\
\hline Observations & 450 & 1037 & & 942 & & & \\
\hline
\end{tabular}

Note: ${ }^{1}$ The definition of public banks included lottery shops with banking services and the definition of private banks included post office with banking services. ${ }^{2}$ Type of building refers to (i) house or apartment or (ii) shack or room. Type of house refers to unique, improvised or collective house. ${ }^{3}$ Probit model presents the marginal effects and multinomial logit presents the relative risk ratios, i.e., exponential of coefficients.

Parentheses denote $P$-values and are significant if 0.05 or below.

Source: World Bank, Survey of Access to Financial Services in Urban Areas of Brazil, 2002. 
Table 15. Econometric Results: The Probability of Using Public Banks for Real Estate Purchase

\begin{tabular}{lccr}
\hline & \multicolumn{3}{c}{ Credit for Real Estate } \\
\cline { 2 - 4 } Dependent variable & Public banks & Private banks & Government finance \\
\hline Econometric Model & \multicolumn{3}{c}{ Multinomial logit } \\
\hline Geographic region & $0.0(0.94)$ & $0.3(0.58)$ & $0.00(0.97)$ \\
Position in the household & $0.1(0.83)$ & $1.2(0.27)$ & $-0.99(0.30)$ \\
Sector of activity & $0.28(0.03)$ & $0.43(0.04)$ & $0.42(0.02)$ \\
Income & $0.84(0.01)$ & $0.07(0.76)$ & $0.98(0.00)$ \\
Observations & & 130 & \\
\end{tabular}

Source: World Bank, Survey of Access to Financial Services in Urban Areas of Brazil, 2002. Parentheses denote $P$-values and are significant if 0.05 or below.

Finally, income is the only variable to have a significant relationship with probability of receiving credit from public banks for real estate purchase. Individuals in the second quintile of income, as compared to the lowest quintile, have a 17 percent lower probability of seeking credit from public banks, (Table 15). Taken together, these results indicate that persons in higher income groups seek public bank services less; and thus could imply some pro-poor orientation of the public banks. 


\section{Summary of Findings and Policy Implications}

$\mathrm{T}$ he preceding chapters have analyzed first, the factors associated with the supply of financial services, particularly in the form of institutional outlets for such services, and next, patterns of use of financial services at the level of individuals in Brazil's urban areas. Combining and synthesizing the results, some key findings to emerge are that the provision of banking services in Brazil has remained broadly unchanged over the last decade. Brazil is not obviously underbanked in terms of international comparisons. Within the country, wide regional differentials in the provision of services are considerably reduced in significance when we correct for differentials in regional GDP and for geographical size. Important new trends are emerging in the form of financial outlets, such as correspondents and ATMs. As shown by the user survey, these have remarkably influenced and increased overall use of financial services, both among the better off and less well to do sections of society. The effective use of banking services is considerably greater than the number of bank accounts alone would suggest.

The survey of individual financial behavior corroborates the importance of location in determining access, but demonstrates that location in terms of the micro characteristics of an area or neighborhood can be as important a discriminator for access, as location in terms of regions or municipalities. More important than region or location, at the user level, are a range of socio-economic characteristics, especially income but also education and (for credit services) wealth, in determining financial access.

Regarding the roles of public and private financial institutions, both the aggregated supply side analysis and the survey of users indicated that there is some association between the less-well-off (lower income groups, less educated persons, and dwellers in less affluent regions) and public banks. However the user survey also showed that the use of public banks varies by type of service. Thus, public banks are popular for payment services (due to the 
outlets of the Caixa Econômica Federal), for all socio-economic groups, and also dominate the provision of housing credit, but in the latter case, largely for the better off groups. For deposit taking and for credit, both the privileged and less privileged socio-economic groups, broadly measured, have some preference for private banks, and with increases in income both increase their proportional use of private banks. Thus in many areas, the user survey corroborates the findings of the supply analysis, that in many respects, public and private banks are broadly substitutable.

\section{Implications for Policy}

The preceding analysis suggests a number of thematic directions which could help to guide policy choices. Given the importance of factors such as income, education and wealth, in determining access, which may be due to asymmetries in information, factors which reduce such asymmetries in information can be important for the expansion of financial access. This may also illustrate the importance of such factors in a situation where contract enforcement is difficult. Finally, it also suggests that economic growth which is sensitive to income distribution will help to expand financial access, thereby establishing a virtuous circle.

Another corollary may be that targeted policies, which particularly address lower income groups, may help to address access. Designing efficient and incentive compatible targeted policies can however be a challenge. For example, basic accounts, minimum packages of financial services, simplified documentation requirements or special financial products, such as payroll loans, designed for low income persons, could be important for raising access. The importance of socio-economic characteristics such as education, in determining access suggest that programs of financial education, financial mentoring, training and twinning and awareness building may also be important for raising financial access.

Equally important are the implications of the analysis which diminish the importance of location in explaining access differentials, after considering different levels of economic activity and population density. Thus, policies which rely largely on the provision of service outlets in all geographical areas may be hard to justify in areas too poor or sparse to justify services. Moreover, such policies cannot ensure that users of financial services in such locations are indeed the poorer segments, better off persons even in these neighborhoods are likely to have been more successful in achieving access. This is a significant comment in the context of Brazil where major efforts to expand access have focused on ensuring that there is at least one financial point of service (branch, service post or correspondent), in each municipality. Combined with this is the finding that regions of the country or even municipalities, are perhaps not the best points of focus for the expansion of access. Rather, location defined at a micro level in terms of neighborhoods, with service expansion targeted at areas or parts of a city with specific microeconomic characteristics (for example, high concentrations of low income housing), may be more appropriate and the provision of financial services in poor urban pockets may be an equal challenge to exclusion in remote regions. 
Finally, in terms of choices between public and private financial institutions, given that there are some specialized services where either public or private banks seem to dominate (for example, public banks for payments or housing), greater competition in these services would be desirable, inviting in private services in housing or in payments (perhaps through an alteration in the present domination of housing finance by one large public institution, or through more competition in the allocation of correspondent franchises). Although the analysis did suggest that persons with lower levels of income tended to use public banks proportionately more, it also showed that along a broad spectrum of deposit and credit services, the roles of these institutions could be largely substitutable. Maintaining a differential role for public banks on the grounds of access may therefore have limited justification. Indeed, as persons become better off, they tend to prefer private services for a broad spectrum of financial transactions. 

APPENDIXES 



\section{Note on Estimation: Urban Financial Survey}

7 his technical note describes the statistical tests used to choose the independent variables of the models and then describes the formulation of the functional forms

of models that were subsequently used in the analysis. The econometric models used to determine the measures of access are also described below.

\section{Chi-square Tests of Independence}

The chi-square "goodness-of-fit" test evaluates the hypothesis that the rows and columns in a two-way table are mutually statistically independent. With dichotomous variables, the chi-square test is similar to the $z$-test that tests the equality of proportions (or the frequency of incidence) between two variables using large-sample statistics. However, unlike the $z$-test, the chi-square test is not restricted to comparisons of only two sample proportions. For variables with multiple categories the chi-square test is the most common technique to evaluate the degree of dependence between rows and columns of the categorized data.

Under the null hypothesis that the distribution of observations in the rows and columns is mutually independent (follow a specified distribution), the chi-square statistic computed indicates the degree to which the distribution variables between the rows and columns differ significantly from the specified norm.

The chi-square statistic for data with $(I-1)(J-1)$ degrees of freedom is computed as:

$$
\chi^{2}=\sum_{i} \sum_{j} \frac{\left(n_{i j}-m_{i j}\right)^{2}}{m_{i j}}
$$


where

$n_{i j}=$ number of observations in $i$-th row and $j$-th column. In our case, $n_{i j}$ is just a count of frequency such that

$$
\begin{gathered}
n_{i}=\sum_{j=1}^{J} n_{i j} \text { and } n_{. j}=\sum_{i=i}^{I} n_{i j}, i=1, \ldots, I \text { and } j=1, \ldots, J \\
n=\sum_{i} \sum_{j} n_{i j}(\text { overall sum }) \\
m_{i j}=\frac{n_{i} \cdot n_{j}}{n}
\end{gathered}
$$

Prior to the regression analysis, chi-square tests were conducted to confirm that the distribution pattern of the dependent variable was different from those that were to be used as the explanatory variables. For example, we checked whether the probability of a woman having a bank account was equal to the probability of a man having a bank account. Only in the cases where the null hypothesis could be rejected were the associated independent variables deemed to be good control or explanatory factors for inclusion in the regression analysis.

\section{Econometric Models}

Qualitative response models were estimated using models for binary response and for multinomial choices. Models of binary responses were designed to take the value 0 for persons who did not fulfill the given criterion (such as having access to financial institutions) and a value of 1 for persons who did satisfy the specified criterion. Such variables were associated with additional information that captured personal characteristics, employment information and location information. Models of multinomial responses associated multivariate variables that followed a logical sequence of progression-such as don't save money, have money in a saving account, have money in a time deposit-account for some independent variables. The second sets of models were thus an expansion of the first set.

In the binary model, we attempted to estimate $E[I / X]$ where $X$ is the vector of independent variables that have some relation with $I$, and $E$ is the expectation operator. Assuming that vector " $I$ " follows a Bernoulli distribution, we used the result:

$$
E[I \mid X]=\operatorname{Pr}(I=1 \mid X)=F(X: \beta)
$$

where $F($.$) denotes the cumulative distribution function of " I$ " conditional on the values of $X$, and ( is an array of parameters which determines this function. In this analysis, we assumed that $X$ comprised of independent and identically distributed variables and that $F($.) was linear in its arguments, resulting in the model:

$$
F(X: \beta)=X^{\prime} \beta+\varepsilon
$$


We also assumed that $\xi$ was independent of $X$. This allowed us to use a logit model for regression where the $F($.$) represented a cumulative distribution function of a logistic nature$ such that:

$$
P(I=1 \mid X)=F\left(X^{\prime} \beta\right) \frac{e^{x^{\prime} \beta}}{1+e^{x^{\prime} \beta}}
$$

Equation (1) could be transformed into

$$
\log \left[P(I=1 \mid X) /(1-P(I=1 \mid X)]=X^{\prime} \beta\right.
$$

or simply

$$
h(I)=X^{\prime} \beta
$$

Equation (2) could then be estimated by Maximum Likelihood Estimation techniques. Unlike conventional linear regression models, the coefficients of the regressions cannot be interpreted as the partial derivatives of the dependent variable with respect to the respective explanatory. The partial effects were computed by:

(a) Estimating the probability of access to financial services of an individual with value $J$ for a characteristic $\mathrm{k}$, which is

$$
P(I=1 \mid X)=F\left(X^{\prime} \beta\right) \frac{e^{x^{\prime} \beta}}{1+e^{x^{\prime} \beta}}
$$

(b) Estimating the average probability for every $J$. The difference between the averages calculated for $J$ and $J+1$ represented the marginal effect of increasing the value of the explanatory variable $\mathrm{k}$ of $\mathrm{J}$ to $J+1$.

Given the limitations of the statistical software used for the analysis which does not calculate the marginal effects of logit regressions automatically, the marginal effects from probit estimation was used as an approximation of the same results. The probit model is similar to logit model, with $F(x \beta)=\phi(x \beta)$, where $\phi$ is the standard cumulative normal distribution.

For analysis of multinomial models, multinomial logit estimation is the most widely used technique. In a choice set $B=\{1, \ldots, m\}$, where $x_{B}=\left(x_{1}, \ldots, x_{m}\right)$ denotes the array of observed attributes of the available alternatives, vector $y_{B}=\left(y_{1}, \ldots, y_{m}\right)$ has a multivariate probability distribution:

$$
f^{i}\left(x_{B}, \theta\right)=\frac{e^{x \beta^{i}}}{\sum_{j \in B} e^{x \beta^{j}}}
$$

with mean $\beta^{\prime} x_{B}$ like in the binomial case.

Using Maximum Likelihood Estimation techniques, the sequential series of outcomes in $y$ could be estimated in terms of the explanatory variables $X$. These results 
could then be used to estimate the coefficients corresponding to each outcome category such as:

$$
\begin{aligned}
& \operatorname{Pr}(y=1)=\frac{e^{x \beta^{1}}}{e^{x \beta^{1}}+e^{x \beta^{2}}+e^{x \beta}} \\
& \operatorname{Pr}(y=2)=\frac{e^{x \beta^{2}}}{e^{x \beta^{1}}+e^{x \beta^{2}}+e^{x \beta^{2}}} \\
& \operatorname{Pr}(y=3)=\frac{e^{x \beta^{3}}}{e^{x \beta^{1}}+e^{x \beta^{2}}+e^{x \beta^{3}}}
\end{aligned}
$$

The limitation of this technique is that the estimated solutions for coefficients $\left(\beta^{1}, \beta^{2}, \beta^{3}\right)$ need not be unique. Hence by arbitrarily setting one of the $\beta^{\prime}$ s at the benchmark value of 0 , the other coefficients can then be interpreted to measure the change relative to the control group.

In this study both types of models and estimation: binomial respondents models, logit and probit and multinomial response models, logit multinomial were used. Also used were linear models to predict the volume of credit requested by individuals and the volume of credit approved in each request. The logarithm of the amount of money request (or approved) for loans was regressed on identifiable personal characteristics such as age, education level, income, etc. The relation estimated was of the type:

$$
E[\ln (Y) \mid X]=g(X),
$$

where

$$
g(X)=\beta_{0}+X_{1} \beta_{1}+\cdots+X_{k} \beta_{k}+\varepsilon
$$

and $Y$ represented the volume of credit requested (approved) and $X$ the characteristics variables. 
APPENDIX B

Statistical Tables 


\begin{tabular}{|c|c|c|c|c|c|c|c|c|c|c|c|c|c|c|}
\hline 1. Number of Institutions & 1993 & 1994 & 1995 & 1996 & 1997 & 1998 & $1998^{1}$ & 1999 & $1999^{1}$ & 2000 & $2000^{1}$ & 2001 & $2001^{1}$ & 2002 \\
\hline Multiple and Commercial Banks² & 241 & 244 & 240 & 229 & 215 & 201 & 185 & 193 & 175 & 191 & 173 & 181 & 160 & 166 \\
\hline Development Banks & 7 & 6 & 6 & 6 & 6 & 6 & 21 & 5 & 18 & 5 & 17 & 4 & 15 & 4 \\
\hline Investment Banks & 17 & 17 & 17 & 23 & 22 & 22 & 128 & 21 & 126 & 19 & 123 & 20 & 121 & 23 \\
\hline Savings Banks (inclu. CEF) & 2 & 2 & 2 & 2 & 2 & 2 & & 1 & & 1 & & 1 & & 1 \\
\hline Finance Companies & 41 & 41 & 42 & 47 & 48 & 42 & 187 & 41 & 182 & 42 & 176 & 39 & 169 & 46 \\
\hline Leasing Companies & 67 & 72 & 78 & 74 & 78 & 80 & 100 & 79 & 103 & 77 & 109 & 71 & 105 & 65 \\
\hline Real Estate/Savings and Loan & 27 & 27 & 23 & 22 & 22 & 21 & 86 & 19 & 77 & 18 & 73 & 18 & 74 & 18 \\
\hline Total these items & 402 & 409 & 408 & 403 & 393 & 374 & 707 & 359 & 681 & 353 & 671 & 334 & 644 & 323 \\
\hline Credit Cooperatives & 877 & 946 & 980 & 956 & 1,015 & 1088 & & 1,183 & & 1,235 & & 1,333 & & 1,374 \\
\hline Micro Credit Companies (SCMs) & & & & & & & & 3 & & 6 & & 14 & & 26 \\
\hline Construction Consortia & 485 & 490 & 462 & 446 & 433 & 422 & & 406 & & 404 & & 397 & & 375 \\
\hline Investment Funds ${ }^{3}$ & 839 & 1,279 & 2,195 & 2,765 & 3,500 & 3617 & & 4,034 & & 4,656 & & 5,195 & & 5,833 \\
\hline Others $^{4}$ & 745 & 734 & 692 & 621 & 564 & 528 & & 524 & & 497 & & 487 & & 475 \\
\hline Total all items & 3,348 & 3,858 & 4,737 & 5,191 & 5,905 & 6,029 & & 6,509 & & 7,151 & & 7,760 & & 8,406 \\
\hline \multicolumn{15}{|c|}{ 2. \% Shares of Different Types of Institutions in Total Number of Institutions } \\
\hline Multiple and Commercial Banks ${ }^{2}$ & 7.20 & 6.32 & 5.07 & 4.41 & 3.64 & 3.33 & & 2.97 & & 2.67 & & 2.33 & & 1.97 \\
\hline Development Banks & 0.21 & 0.16 & 0.13 & 0.12 & 0.10 & 0.10 & & 0.08 & & 0.07 & & 0.05 & & 0.05 \\
\hline Investment Banks & 0.51 & 0.44 & 0.36 & 0.44 & 0.37 & 0.36 & & 0.32 & & 0.27 & & 0.26 & & 0.27 \\
\hline Savings Banks (inclu. CEF) & 0.06 & 0.05 & 0.04 & 0.04 & 0.03 & 0.03 & & 0.02 & & 0.01 & & 0.01 & & 0.01 \\
\hline Finance Companies & 1.22 & 1.06 & 0.89 & 0.91 & 0.81 & 0.70 & & 0.63 & & 0.59 & & 0.50 & & 0.55 \\
\hline Leasing Companies & 2.00 & 1.87 & 1.65 & 1.43 & 1.32 & 1.33 & & 1.21 & & 1.08 & & 0.91 & & 0.77 \\
\hline Real Estate/Savings and Loan & 0.81 & 0.70 & 0.49 & 0.42 & 0.37 & 0.35 & & 0.29 & & 0.25 & & 0.23 & & 0.21 \\
\hline Credit Cooperatives & 26.19 & 24.52 & 20.69 & 18.42 & 17.19 & 18.05 & & 18.17 & & 17.27 & & 17.18 & & 16.35 \\
\hline
\end{tabular}




\begin{tabular}{|c|c|c|c|c|c|c|c|c|c|c|}
\hline Micro Credit Companies (SCMs) & 0.00 & 0.00 & 0.00 & 0.00 & 0.00 & 0.00 & 0.05 & 0.08 & 0.18 & 0.31 \\
\hline Construction Consortia & 14.49 & 12.70 & 9.75 & 8.59 & 7.33 & 7.00 & 6.24 & 5.65 & 5.12 & 4.46 \\
\hline Investment Funds ${ }^{3}$ & 25.06 & 33.15 & 46.34 & 53.27 & 59.27 & 59.99 & 61.98 & 65.11 & 66.95 & 69.39 \\
\hline Others ${ }^{4}$ & 22.25 & 19.03 & 14.61 & 11.96 & 9.55 & 8.76 & 8.05 & 6.95 & 6.28 & 5.65 \\
\hline Total Shares & 100.0 & 100.0 & 100.0 & 100.0 & 100.0 & 100.0 & 100.0 & 100.0 & 100.0 & 100.0 \\
\hline \multicolumn{11}{|c|}{ 3. Assets of Institutions (\% total financial system) } \\
\hline Multiple and Commercial Banks² & 68.84 & 67.45 & 68.58 & 67.86 & 68.37 & 65.74 & 66.63 & 69.04 & 72.84 & \\
\hline Development Banks & 8.14 & 8.44 & 7.81 & 7.08 & 7.69 & 10.02 & 10.11 & 10.50 & 10.52 & \\
\hline Investment Banks & 3.08 & 3.10 & 1.24 & 1.67 & 1.53 & 0.90 & 1.02 & 0.91 & 1.21 & \\
\hline Savings Banks (inclu. CEF) & 11.92 & 12.16 & 13.77 & 13.64 & 13.83 & 14.01 & 13.82 & 12.63 & 9.07 & \\
\hline Finance Companies & 0.33 & 0.56 & 0.29 & 0.59 & 0.52 & 0.41 & 0.53 & 0.85 & 0.49 & \\
\hline Leasing Companies & 2.43 & 2.90 & 3.33 & 3.36 & 4.17 & 5.24 & 5.42 & 3.87 & 3.29 & \\
\hline Real Estate/Savings and Loan & 1.23 & 1.23 & 1.18 & 1.11 & 1.09 & 1.10 & 0.45 & 0.37 & 0.33 & \\
\hline Credit Cooperatives & 0.10 & 0.15 & 0.20 & 0.25 & 0.31 & 0.41 & 0.54 & 0.62 & 0.75 & \\
\hline Construction Consortia & n.a. & n.a. & n.a. & n.a. & n.a. & n.a. & n.a. & n.a. & n.a. & \\
\hline Investment Funds ${ }^{3}$ & n.a. & n.a. & n.a. & n.a. & n.a. & n.a. & n.a. & n.a. & n.a. & \\
\hline Micro Credit Companies (SCMs) & - & - & - & - & - & - & - & 0.00 & 0.00 & \\
\hline Others $^{5}$ & 3.93 & 4.01 & 3.60 & 4.44 & 2.49 & 2.17 & 1.48 & 1.21 & 1.50 & \\
\hline Total & 100.0 & 100.0 & 100.0 & 100.0 & 100.0 & 100.0 & 100.0 & 100.0 & 100.0 & \\
\hline
\end{tabular}

Notes: ${ }^{1}$ Considers Single Institutions and Portfolios of the same type. ${ }^{2}$ Includes Branches of Foreign Banks. ${ }^{3}$ Includes investment funds authorized and in operation. ${ }^{4}$ Mortgage, Security Brokerage, Exchange Brokerage, Security Distribution companies and Development Agencies (including institutions authorized to operate by Central Bank of Brazil, including group buyer consortia). ${ }^{5}$ Same as No. 4 less Exchange Brokerage companies.

Source: Central Bank of Brazil. 


\begin{tabular}{|c|c|c|c|c|c|c|c|c|c|}
\hline Type of service outlet & 1994 & 1995 & 1996 & 1997 & 1998 & 1999 & 2000 & 2001 & 2002 \\
\hline Branches & 17,400 & 17,181 & 16,583 & 16,255 & 16,002 & 16,189 & 16,396 & 16,841 & 17,049 \\
\hline Bank Service Outposts (a) internal (PABs) & 10,125 & 9,075 & 8,268 & 7,787 & 7,211 & 6,614 & 6,562 & 7,318 & 7,108 \\
\hline in municip. with banking branches & 9,776 & 8,780 & 7,987 & 7,513 & 6,987 & 6,425 & 6,407 & 7,183 & 6,988 \\
\hline in municip. with no banking branches & 349 & 295 & 281 & 274 & 224 & 189 & 155 & 135 & 120 \\
\hline Bank Service Outposts (b) external (PAAs) & - & - & - & 52 & 334 & 503 & 582 & 619 & 654 \\
\hline ATMs_Individual Network (PAE) & 2,874 & 3,922 & 4,841 & 6,015 & 6,709 & 10,808 & 12,681 & 14,923 & 20,347 \\
\hline ATMs—Associate Network (PAE) & 572 & 674 & 696 & 744 & 1,010 & 1,369 & 1,772 & 1,825 & 2,081 \\
\hline Coop. Services (PAC) & 48 & 305 & 361 & 445 & 600 & 849 & 1,129 & 1,344 & 1,485 \\
\hline Rural Credit Outposts (PACRE) & 10 & 9 & 8 & 7 & 7 & 5 & 5 & 5 & 2 \\
\hline Payment Posts (PAP) & 1,786 & 1,643 & 1,340 & 1,164 & 942 & 719 & 697 & 402 & 325 \\
\hline Other (PCO \& UAD) & 672 & 689 & 610 & 508 & 505 & 506 & 520 & 553 & 566 \\
\hline Total these items & 33,487 & 33,498 & 32,707 & 32,977 & 33,320 & 37,562 & 40,344 & 43,830 & 49,617 \\
\hline $\begin{array}{l}\text { Bank correspondents } \\
\text { o/w Lottery shops }\end{array}$ & & & & & & & $\begin{array}{r}10,589 \\
6,253\end{array}$ & $\begin{array}{r}12,311 \\
7,823\end{array}$ & $\begin{array}{r}16,453 \\
8,961\end{array}$ \\
\hline Others & & & & & & & & 4 & 2,083 \\
\hline Total all items & 33,487 & 33,498 & 32,707 & 32,977 & 33,320 & 37,562 & 50,933 & 56,141 & 66,070 \\
\hline Municipality-level services & 1994 & 1995 & 1996 & 1997 & 1998 & 1999 & 2000 & 2001 & 2002 \\
\hline Municipalities & 5,011 & 5,076 & 5,300 & 5,546 & 5,597 & 5,626 & 5,636 & 5,654 & 5,658 \\
\hline Municip. with no services ${ }^{1}$ & 1,137 & 1,223 & 1,474 & 1,749 & 1,739 & 1,679 & 1,659 & 1,681 & 1,665 \\
\hline Municip. with one outpost & 1,402 & 1,488 & 1,597 & 1,659 & 1,773 & 1,906 & 1,972 & 2,013 & 2,060 \\
\hline Mun. with 1 Branch & 1,402 & 1,488 & 1,597 & 1,607 & 1,439 & 1,403 & 1,390 & 1,394 & 1,406 \\
\hline With PAA & - & - & - & 52 & 334 & 503 & 582 & 619 & 654 \\
\hline
\end{tabular}

Note: ${ }^{1}$ These numbers do not consider the number of Banking Service Outlets.

Source: Central Bank of Brazil. 


\begin{tabular}{|c|c|c|c|c|c|c|}
\hline & March 1995 & 1997 & 1998 & 1999 & 2000 & 2001 \\
\hline \multicolumn{7}{|l|}{ Branches } \\
\hline Federal banks & 7,232 & 6,552 & 5,260 & 5,615 & 5,472 & 5,611 \\
\hline State banks & 1,863 & 1,332 & 2,267 & 1,842 & 1,084 & 1,084 \\
\hline o/w Caixa Económica Federal & & & & & 1,693 & 1,689 \\
\hline Múltiple and Comercial Banks & & & & & 4,863 & 5,006 \\
\hline Private domestic banks & 4,507 & 6,252 & 6,085 & 5,587 & 6,147 & 6,347 \\
\hline o/w Banks with Foreign Participation & & & & & 758 & 930 \\
\hline Foreign banks & 915 & 2,254 & 2,390 & 3,145 & 3,693 & 3,799 \\
\hline Total Branches & 14,517 & 16,390 & 16,002 & 16,189 & 16,396 & 16,841 \\
\hline \multicolumn{7}{|l|}{ Other Services } \\
\hline Bank Service Ouposts (a) internal (PABs) & & & & & 6,636 & 7,323 \\
\hline ATMs (PAE) & & & & & 12,675 & 14,986 \\
\hline Bank Service Ouposts (b) external (PAAs) & & & & & 582 & 619 \\
\hline Total all items & & & & & 36,289 & 39,769 \\
\hline
\end{tabular}

Source: Central Bank of Brazil. 


\begin{tabular}{|c|c|c|c|c|c|c|}
\hline & 1996 & 1997 & 1998 & 1999 & 2000 & $2001^{1}$ \\
\hline \multicolumn{7}{|l|}{ Net Worth } \\
\hline Banks under Foreign Control & 10.29 & 14.29 & 21.86 & 25.46 & 28.31 & 30.72 \\
\hline Private Banks & 55.32 & 51.82 & 49.75 & 46.69 & 50.33 & 51.14 \\
\hline Public Banks (+ State Savings Bank) & 12.40 & 11.49 & 11.35 & 11.10 & 5.66 & 3.46 \\
\hline CEF & 8.85 & 9.09 & 5.42 & 5.22 & 3.82 & 3.90 \\
\hline BB & 11.87 & 11.76 & 10.03 & 9.73 & 9.89 & 8.76 \\
\hline Credit Cooperatives & 1.27 & 1.55 & 1.59 & 1.80 & 1.99 & 2.02 \\
\hline Total & 100.0 & 100.0 & 100.0 & 100.0 & 100.0 & 100.0 \\
\hline \multicolumn{7}{|l|}{ Assets } \\
\hline Banks under Foreign Control & 9.79 & 12.82 & 18.38 & 23.19 & 27.41 & 29.86 \\
\hline Private Banks & 39.00 & 36.76 & 35.29 & 33.11 & 35.23 & 37.21 \\
\hline Public Banks (+ State Savings Bank) & 21.92 & 19.06 & 11.37 & 10.23 & 5.62 & 4.30 \\
\hline CEF & 16.47 & 16.57 & 17.02 & 17.06 & 15.35 & 10.97 \\
\hline BB & 12.52 & 14.42 & 17.44 & 15.75 & 15.63 & 16.76 \\
\hline Credit Cooperatives & 0.30 & 0.37 & 0.50 & 0.66 & 0.76 & 0.9 \\
\hline Total & 100.0 & 100.0 & 100.0 & 100.0 & 100.0 & 100.0 \\
\hline \multicolumn{7}{|l|}{ Deposits } \\
\hline Banks under Foreign Control & 4.36 & 7.54 & 15.14 & 16.80 & 21.14 & 20.14 \\
\hline Private Banks & 34.06 & 32.85 & 33.08 & 31.82 & 33.93 & 35.33 \\
\hline Public Banks (+ State Savings Bank) & 18.66 & 17.09 & 13.26 & 11.54 & 7.36 & 7.15 \\
\hline CEF & 26.58 & 24.05 & 20.52 & 19.91 & 19.49 & 19.09 \\
\hline BB & 16.00 & 18.00 & 17.41 & 19.14 & 17.05 & 16.98 \\
\hline Credit Cooperatives & 0.34 & 0.47 & 0.59 & 0.79 & 1.03 & 1.31 \\
\hline Total & 100.0 & 100.0 & 100.0 & 100.0 & 100.0 & 100.0 \\
\hline
\end{tabular}




\begin{tabular}{|c|c|c|c|c|c|c|}
\hline \multicolumn{7}{|l|}{ Credit Operations } \\
\hline Banks under Foreign Control & 8.64 & 11.71 & 14.88 & 19.75 & 25.16 & 31.51 \\
\hline Private Banks & 32.74 & 35.35 & 30.97 & 31.66 & 34.53 & 42.13 \\
\hline Public Banks (+ State Savings Bank) & 23.47 & 10.30 & 8.86 & 8.13 & 5.12 & 3.09 \\
\hline CEF & 24.00 & 30.93 & 32.31 & 28.74 & 23.00 & 7.13 \\
\hline BB & 10.62 & 10.97 & 12.05 & 10.58 & 10.95 & 14.53 \\
\hline Credit Cooperatives & 0.53 & 0.74 & 0.93 & 1.14 & 1.24 & 1.61 \\
\hline Total & 100.0 & 100.0 & 100.0 & 100.0 & 100.0 & 100.0 \\
\hline
\end{tabular}

Source: Central Bank of Brazil. 


\begin{tabular}{|c|c|c|c|c|c|c|c|c|c|c|c|c|}
\hline & $\begin{array}{l}\text { Mult. banks } \\
\text { and comm } \\
\text { banks }\end{array}$ & $\begin{array}{c}\text { Dev. } \\
\text { banks }\end{array}$ & $\begin{array}{c}\text { Inv. } \\
\text { banks }\end{array}$ & $\begin{array}{c}\text { Sav. } \\
\text { banks }\end{array}$ & $\begin{array}{l}\text { Fin. } \\
\text { comp. }\end{array}$ & $\begin{array}{l}\text { Leas. } \\
\text { comp. }\end{array}$ & $\begin{array}{l}\text { Real est/ } \\
\text { sav. \& } \\
\text { loan }\end{array}$ & $\begin{array}{l}\text { Micro cred. } \\
\text { comp. }\end{array}$ & coop. & $\begin{array}{c}\text { Constr. } \\
\text { consort. }\end{array}$ & Others & TOTAL \\
\hline \multicolumn{13}{|l|}{2002} \\
\hline Northeast & 12 & 0 & 0 & 0 & 2 & 2 & 6 & 3 & 154 & 26 & 36 & 241 \\
\hline North & 3 & 0 & 0 & 0 & 0 & 0 & 1 & 1 & 82 & 4 & 8 & 99 \\
\hline Central-West & 4 & 0 & 2 & 1 & 1 & 1 & 2 & 1 & 129 & 37 & 3 & 181 \\
\hline Southeast & 131 & 3 & 21 & 0 & 31 & 56 & 5 & 25 & 760 & 186 & 284 & 1502 \\
\hline South & 16 & 1 & 0 & 0 & 12 & 6 & 4 & 7 & 305 & 123 & 39 & 513 \\
\hline Total 2002 & 166 & 4 & 23 & 1 & 46 & 65 & 18 & 37 & 1,430 & 376 & 370 & 2,536 \\
\hline \multicolumn{13}{|l|}{2001} \\
\hline Northeast & 13 & 0 & 0 & 0 & 2 & 2 & 6 & 2 & 146 & 28 & 36 & 235 \\
\hline North & 3 & 0 & 0 & 0 & 0 & 0 & 1 & 0 & 78 & 4 & 7 & 93 \\
\hline Central-West & 4 & 0 & 2 & 1 & 1 & 1 & 2 & 1 & 125 & 40 & 5 & 182 \\
\hline Southeast & 143 & 3 & 18 & 0 & 31 & 61 & 5 & 18 & 759 & 200 & 303 & 1541 \\
\hline South & 18 & 1 & 0 & 0 & 8 & 8 & 4 & 2 & 271 & 127 & 44 & 483 \\
\hline Total 2001 & 181 & 4 & 20 & 1 & 42 & 72 & 18 & 23 & 1,379 & 399 & 395 & 2,534 \\
\hline \multicolumn{13}{|l|}{2000} \\
\hline Northeast & 13 & 1 & 0 & 0 & 2 & 2 & 6 & 0 & 124 & 27 & 35 & 210 \\
\hline North & 3 & 0 & 0 & 0 & 0 & 0 & 1 & 0 & 72 & 3 & 7 & 86 \\
\hline Central-West & 4 & 0 & 2 & 1 & 2 & 1 & 2 & 1 & 112 & 39 & 5 & 169 \\
\hline Southeast & 152 & 3 & 17 & 0 & 32 & 67 & 5 & 9 & 753 & 209 & 324 & 1571 \\
\hline South & 20 & 1 & 0 & 0 & 7 & 8 & 4 & 1 & 250 & 129 & 49 & 469 \\
\hline Total 2000 & 192 & 5 & 19 & 1 & 43 & 78 & 18 & 11 & 1,311 & 407 & 420 & 2,505 \\
\hline
\end{tabular}




\begin{tabular}{|c|c|c|c|c|c|c|c|c|c|c|c|c|}
\hline \multicolumn{13}{|l|}{ Dec 1999} \\
\hline Northeast & 14 & 1 & 0 & 0 & 2 & 3 & 7 & 0 & 110 & 24 & 36 & 197 \\
\hline North & 3 & 0 & 0 & 0 & 0 & 0 & 1 & 0 & 64 & 3 & 7 & 78 \\
\hline Central-West & 4 & 0 & 2 & 1 & 2 & 1 & 2 & 0 & 104 & 39 & 4 & 159 \\
\hline Southeast & 153 & 3 & 19 & 0 & 31 & 69 & 5 & 4 & 740 & 214 & 336 & 1574 \\
\hline South & 20 & 1 & 0 & 0 & 7 & 8 & 4 & 0 & 235 & 126 & 50 & 451 \\
\hline Total Dec 1999 & 194 & 5 & 21 & 1 & 42 & 81 & 19 & 4 & 1,253 & 406 & 433 & 2,459 \\
\hline \multicolumn{13}{|l|}{ Jan 1999} \\
\hline Northeast & 15 & 1 & 0 & 0 & 2 & 2 & 7 & 0 & 105 & 25 & 36 & 193 \\
\hline North & 5 & 0 & 0 & 0 & 0 & 0 & 1 & 0 & 58 & 3 & 4 & 71 \\
\hline Central-West & 4 & 0 & 2 & 1 & 2 & 1 & 2 & 0 & 96 & 42 & 3 & 153 \\
\hline Southeast & 160 & 3 & 19 & 0 & 34 & 73 & 6 & 0 & 721 & 220 & 346 & 1582 \\
\hline South & 20 & 2 & 1 & 0 & 6 & 7 & 4 & 0 & 224 & 131 & 54 & 449 \\
\hline Total Jan 1999 & 204 & 6 & 22 & 1 & 44 & 83 & 20 & 0 & 1,204 & 421 & 443 & 2,448 \\
\hline
\end{tabular}

Source: Central Bank of Brazil. 


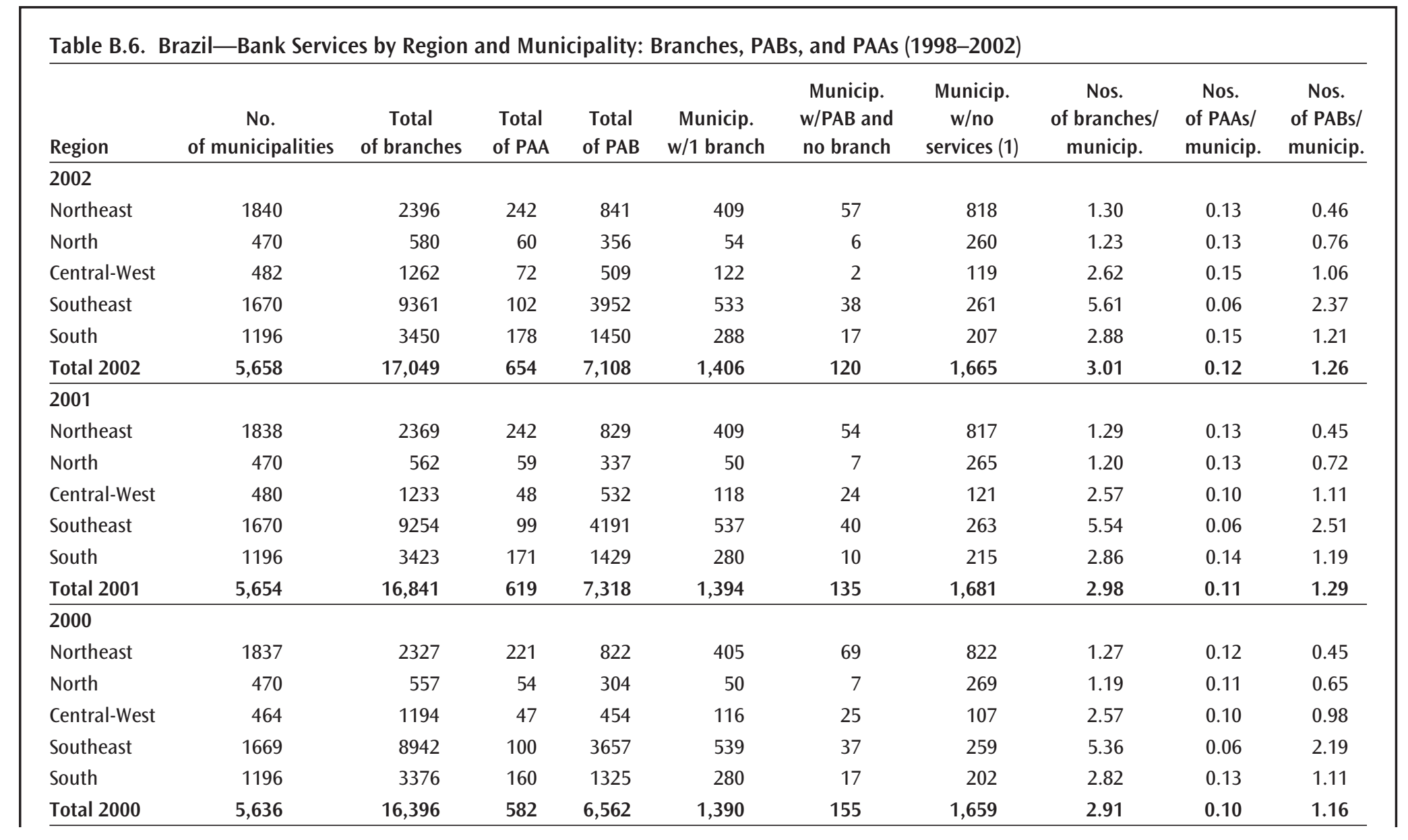




\begin{tabular}{|c|c|c|c|c|c|c|c|c|c|c|}
\hline \multicolumn{11}{|l|}{1999} \\
\hline Northeast & 1846 & 2331 & n.a. & 853 & 413 & 83 & 841 & 1.26 & n.a. & 0.46 \\
\hline North & 471 & 552 & n.a. & 294 & 50 & 8 & 284 & 1.17 & n.a. & 0.62 \\
\hline Central-West & 464 & 1185 & n.a. & 457 & 115 & 25 & 105 & 2.55 & n.a. & 0.98 \\
\hline Southeast & 1669 & 8763 & n.a. & 3699 & 542 & 54 & 263 & 5.25 & n.a. & 2.22 \\
\hline South & 1176 & 3358 & n.a. & 1311 & 283 & 19 & 186 & 2.86 & n.a. & 1.11 \\
\hline Total 1999 & 5,626 & 16,189 & n.a. & 6,614 & 1,403 & 189 & 1,679 & 2.88 & n.a. & 1.18 \\
\hline \multicolumn{11}{|l|}{1998} \\
\hline Northeast & 1826 & 2360 & n.a. & 852 & 444 & 86 & 860 & 1.29 & n.a. & 0.47 \\
\hline North & 470 & 552 & n.a. & 285 & 53 & 9 & 315 & 1.17 & n.a. & 0.61 \\
\hline Central-West & 456 & 1200 & n.a. & 545 & 114 & 44 & 93 & 2.63 & n.a. & 1.20 \\
\hline Southeast & 1669 & 8527 & n.a. & 4072 & 542 & 60 & 292 & 5.11 & n.a. & 2.44 \\
\hline South & 1176 & 3363 & n.a. & 1457 & 286 & 25 & 179 & 2.86 & n.a. & 1.24 \\
\hline Total 1998 & 5,597 & 16,002 & n.a. & 7,211 & 1,439 & 224 & 1,739 & 2.86 & n.a. & 1.29 \\
\hline
\end{tabular}

Source: Central Bank of Brazil. 


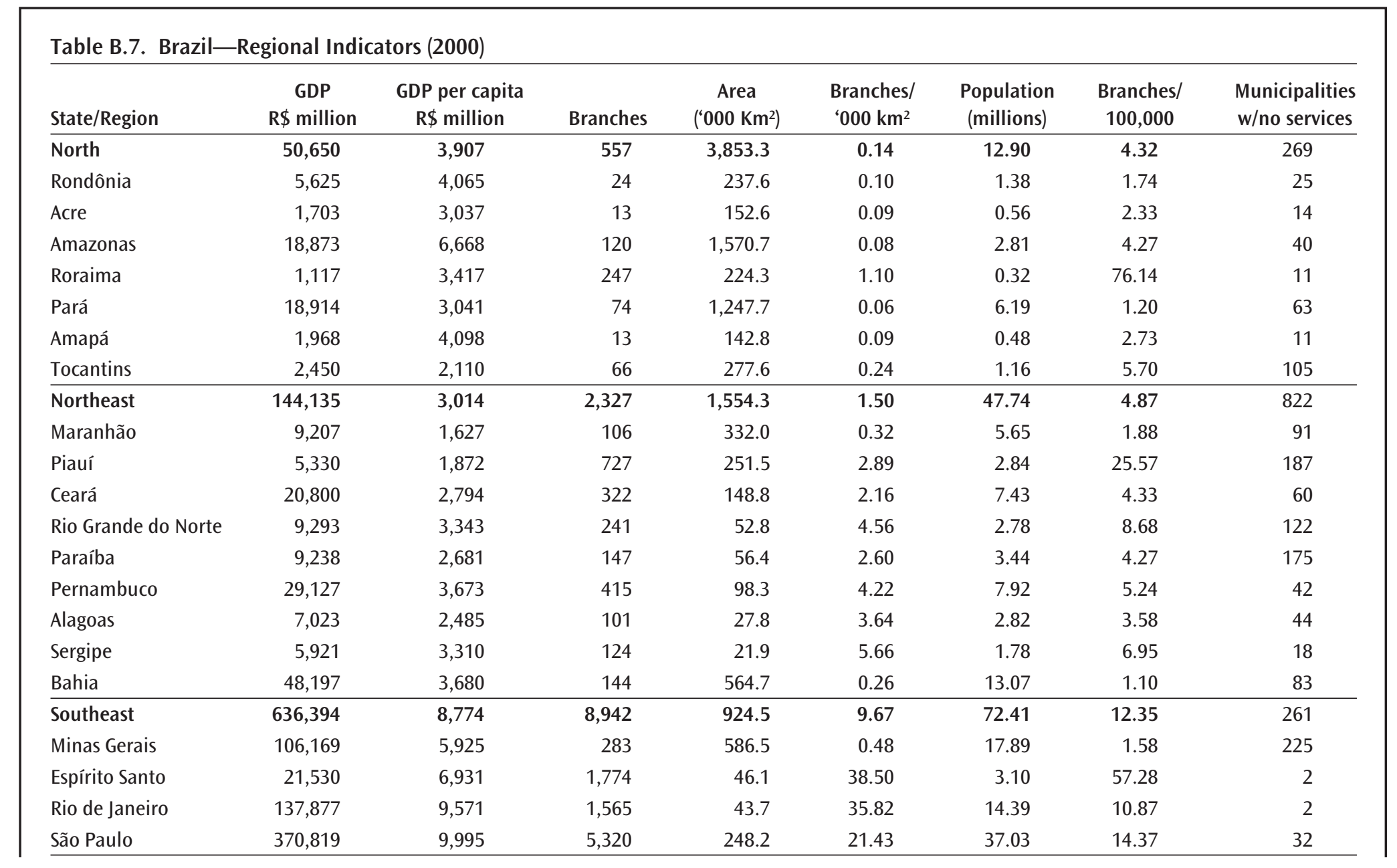




\begin{tabular}{|c|c|c|c|c|c|c|c|c|}
\hline South & 193,534 & 7,692 & 3,376 & 576.4 & 5.86 & 25.11 & 13.45 & 202 \\
\hline Paraná & 65,969 & 6,882 & 1,250 & 199.3 & 6.27 & 9.56 & 13.07 & 63 \\
\hline Santa Catarina & 42,428 & 7,902 & 1,344 & 95.3 & 14.10 & 5.36 & 25.09 & 44 \\
\hline Rio Grande do Sul & 85,138 & 8,341 & 782 & 281.7 & 2.78 & 10.19 & 7.68 & 95 \\
\hline Center-West & 76,542 & 6,559 & 1,194 & $1,606.4$ & 0.74 & 11.64 & 10.26 & 107 \\
\hline Mato Grosso do Sul & 11,861 & 5,697 & 261 & 357.1 & 0.73 & 2.08 & 12.56 & 13 \\
\hline Mato Grosso & 13,428 & 5,342 & 510 & 903.4 & 0.56 & 2.50 & 20.36 & 47 \\
\hline Goiás & 21,665 & 4,316 & 208 & 340.1 & 0.61 & 5.00 & 4.16 & 39 \\
\hline Distrito Federal & 29,587 & 14,405 & 215 & 5.8 & 37.06 & 2.05 & 10.48 & 8 \\
\hline Brazil & $1,101,255$ & 6,473 & 16,396 & $8,514.9$ & 1.93 & 169.80 & 9.66 & 1,661 \\
\hline
\end{tabular}

Source: IBGE. 


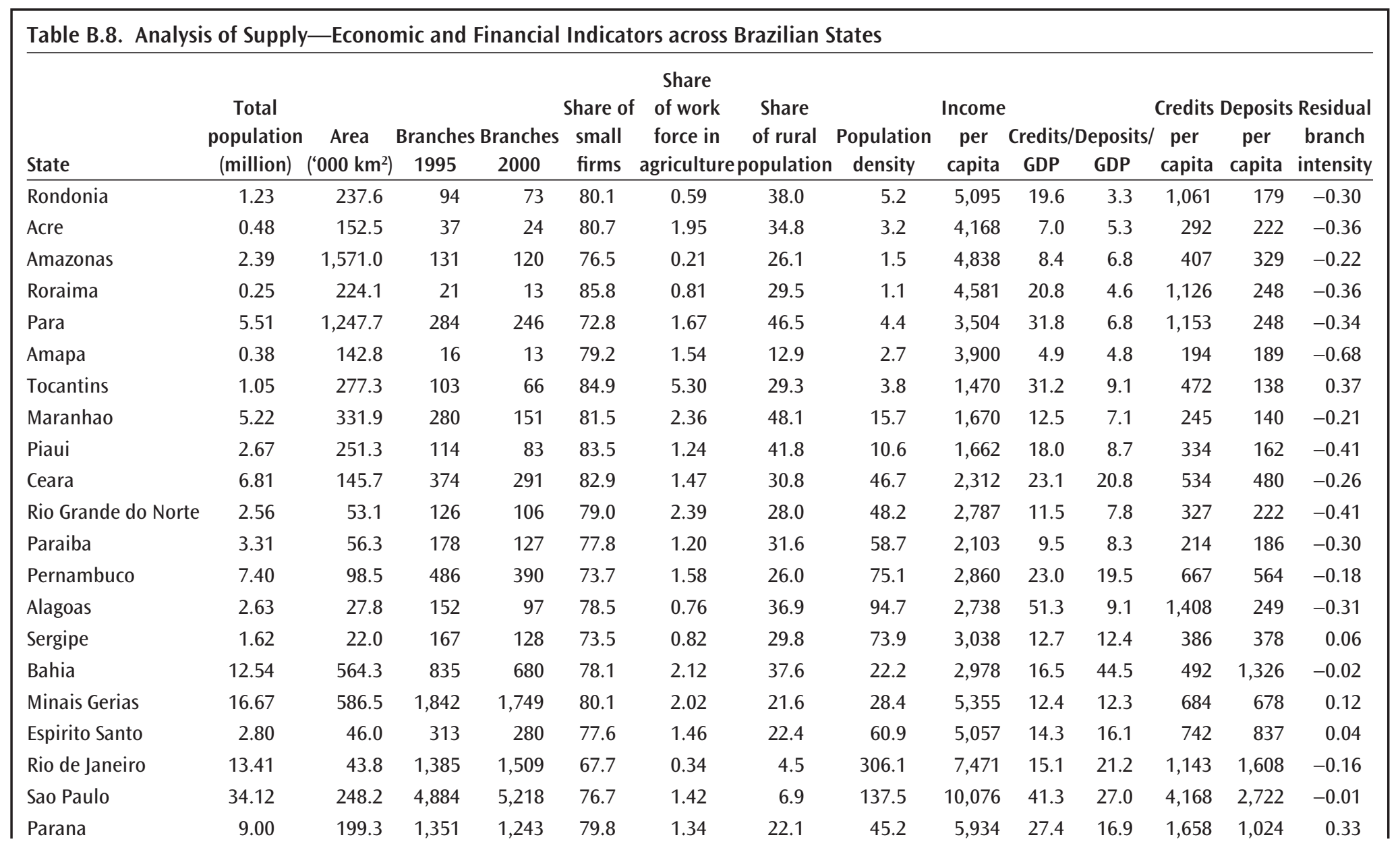




\begin{tabular}{|lrrrrrrrrrrrrr|r} 
Santa Catarina & 4.88 & 95.3 & 814 & 776 & 79.9 & 1.55 & 26.9 & 51.2 & 5,764 & 16.8 & 12.6 & 986 & 739 & 0.54 \\
Rio Grande do Sul & 9.63 & 268.8 & 1,462 & 1,331 & 83.7 & 1.17 & 21.3 & 35.8 & 6,608 & 23.5 & 17.1 & 1,574 & 1,148 & 0.30 \\
Mato Grosso do Sul & 1.93 & 357.1 & 297 & 214 & 79.6 & 3.81 & 16.8 & 5.4 & 6,516 & 24.2 & 4.5 & 1,574 & 295 & 0.29 \\
Mato Grosso & 2.24 & 903.4 & 284 & 208 & 81.8 & 3.37 & 24.2 & 2.5 & 4,398 & 36.3 & 5.6 & 1,643 & 254 & 0.42 \\
Goias & 4.51 & 340.1 & 589 & 504 & 80.5 & 1.70 & 14.2 & 13.3 & 4,082 & 38.8 & 7.6 & 1,665 & 327 & 0.42 \\
Brasilia, DF & 1.82 & 5.8 & 228 & 205 & 74.1 & 0.33 & 7.1 & 314.0 & 12,854 & 122.3 & 87.9 & 15,716 & 11,295 & -0.32 \\
& & & & & & & & & & & & & & \\
\hline
\end{tabular}

Notes: Unless otherwise indicated, all numbers are for 1996. The residual branch intensity is the deviation of the actual from the predicted number of branchesrelative to the number predicted from a regression of the number of branches on GDP, land area, and population for 28 countries. Positive numbers indicate that the actual number of branches is higher than the predicted number.

Sources: World Bank staff estimates; data provided by Central Bank of Brazil, IPEA and IBGE. 
Table B.9. Analysis of Supply-Branch Intensity a Cross Different Ownership Groups and over Time

\begin{tabular}{lccccc}
\hline & Date & Federal banks & State banks & Private banks & Foreign banks \\
\hline Assets per branch & 1995 & 32,730 & 17,108 & 26,920 & 27,661 \\
Loans per branch & 1995 & 17,907 & 6,900 & 11,929 & 15,761 \\
Deposits per branch & 1995 & 13,984 & 7,494 & 11,544 & 10,007 \\
Employees per branch & 1995 & 43.5 & 36.4 & 37.5 & 48.4 \\
Assets per branch & 1997 & 43,442 & 31,094 & 27,613 & 36,416 \\
Loans per branch & 1997 & 21,340 & 8,583 & 11,031 & 14,489 \\
Deposits per branch & 1997 & 16,674 & 14,869 & 9,722 & 10,350 \\
Employees per branch & 1997 & 38.1 & 27.3 & 29.3 & 28.2 \\
Assets per branch & 2000 & 45,156 & 19,115 & 29,852 & 54,129 \\
Loans per branch & 2000 & 23,040 & 4,937 & 13,451 & 23,149 \\
Deposits per branch & 2000 & 15,542 & 12,212 & 10,312 & 12,812 \\
Employees per branch & 2000 & 39.4 & 27.8 & 26.6 & 24.0 \\
& & & & & \\
\hline
\end{tabular}

Notes: The financial data are in R\$, deflated by the CPI (base year $=1995)$. All ratios are calculated for the aggregates and are for March 1995, December 1997 and September 2000. One bank is excluded because of data problems. Note that the numbers for 2000 in tables 5.1 and A2 are not the same because of the deflating. The base period is 1995.

Source: World Bank staff estimates; data provided by Central Bank of Brazil. 
Table B.10. Analysis of Supply-Structure of the Loan Portfolio across Brazilian Banks over Time

\begin{tabular}{lccccc}
\hline & Period & Federal banks & State banks & Private banks & Foreign banks \\
\hline Private Borrowers & 1995 & 72.8 & 69.1 & 97.2 & 98.0 \\
Agriculture & 1995 & 16.8 & 4.8 & 3.1 & 1.9 \\
Residential Mortgage & 1995 & 34.6 & 30.1 & 15.8 & 5.1 \\
Individuals & 1995 & 3.1 & 10.3 & 12.6 & 12.8 \\
Federal Government & 1995 & 7.3 & 0.3 & 0.2 & 0.2 \\
State Government & 1995 & 19.0 & 27.4 & 2.1 & 0.7 \\
Private Borrowers & 1997 & 78.4 & 94.0 & 98.0 & 99.2 \\
Agriculture & 1997 & 16.3 & 7.4 & 5.9 & 6.7 \\
Residential Mortgage & 1997 & 44.4 & 32.8 & 9.7 & 4.8 \\
Individuals & 1997 & 4.0 & 16.5 & 15.5 & 20.8 \\
Federal Government & 1997 & 5.1 & $\mathbf{0 . 1}$ & $\mathbf{0 . 3}$ & 0.0 \\
State Government & 1997 & 14.9 & 2.0 & 1.1 & 0.2 \\
Private Borrowers & 2000 & 76.6 & 98.9 & 98.9 & 99.4 \\
Agriculture & 2000 & 13.6 & 9.8 & 5.0 & 4.0 \\
Residential Mortgage & 2000 & 42.2 & 26.0 & 6.5 & 4.8 \\
Individuals & 2000 & 7.6 & 24.5 & 17.8 & 23.1 \\
Federal Government & 2000 & 19.3 & $\mathbf{0 . 0}$ & 1.0 & 0.4 \\
State Government & 2000 & 3.0 & 0.3 & 0.1 & 0.1 \\
& & & & & \\
\hline
\end{tabular}

Note: Ratios are for aggregates and are for March 1995, December 1997 and September 2000. Source: World Bank staff estimates; data provided by Central Bank of Brazil. 
Table B.11. Analysis of Demand-Urban Survey of Access and Geographic Location

\begin{tabular}{|c|c|c|c|c|c|}
\hline & Northeast & North & Center-west & Southeast & South \\
\hline Had a Bank Account & $\begin{array}{r}29 \\
(0.00)\end{array}$ & $\begin{array}{r}25 \\
(0.00)\end{array}$ & $\begin{array}{r}53 \\
(0.00)\end{array}$ & $\begin{array}{r}45 \\
(0.00)\end{array}$ & $\begin{array}{r}55 \\
(0.00)\end{array}$ \\
\hline $\begin{array}{l}\text { Used banks as their } \\
\text { primary financial institution }\end{array}$ & 38 & 30 & 48 & 50 & 42 \\
\hline $\begin{array}{l}\text { Used correspondents banks as the } \\
\text { primary financial institution }\end{array}$ & 53 & 70 & 52 & 48 & 53 \\
\hline Used mainly Non-Bank Institutions & $\begin{array}{r}9 \\
(0.00)\end{array}$ & $(\overline{0.00)}$ & $\begin{array}{r}1 \\
(0.00)\end{array}$ & $\begin{array}{r}2 \\
(0.00)\end{array}$ & $\begin{array}{r}5 \\
(0.00)\end{array}$ \\
\hline Used mainly Private Banks & 27 & 16 & 28 & 34 & 26 \\
\hline Used mainly Public Banks & $\begin{array}{r}73 \\
(0.00)\end{array}$ & $\begin{array}{r}84 \\
(0.00)\end{array}$ & $\begin{array}{r}72 \\
(0.00)\end{array}$ & $\begin{array}{r}66 \\
(0.00)\end{array}$ & $\begin{array}{r}74 \\
(0.00)\end{array}$ \\
\hline $\begin{array}{l}\text { Reached the Financial } \\
\text { Institution on foot }\end{array}$ & $\begin{array}{r}55 \\
(0.00)\end{array}$ & $\begin{array}{r}24 \\
(0.00)\end{array}$ & $\begin{array}{r}59 \\
(0.00)\end{array}$ & $\begin{array}{r}57 \\
(0.00)\end{array}$ & $\begin{array}{r}38 \\
(0.00)\end{array}$ \\
\hline $\begin{array}{l}\text { Had a Saving or a Current } \\
\text { or a Term Deposit Account }\end{array}$ & $\begin{array}{r}19 \\
(0.00)\end{array}$ & $\begin{array}{r}6 \\
(0.00)\end{array}$ & $\begin{array}{r}50 \\
(0.00)\end{array}$ & $\begin{array}{r}28 \\
(0.00)\end{array}$ & $\begin{array}{r}38 \\
(0.00)\end{array}$ \\
\hline Had deposits in Public Sector & 3 & 10 & 21 & 11 & 33 \\
\hline Had deposits in Private Sector & 6 & 7 & 30 & 22 & 16 \\
\hline Had deposits in Other Sectors & - & 4 & 10 & 1 & 0 \\
\hline Didn't have deposits & $\begin{array}{r}90 \\
(0.00)\end{array}$ & $\begin{array}{r}79 \\
(0.00)\end{array}$ & $\begin{array}{r}39 \\
(0.00)\end{array}$ & $\begin{array}{r}66 \\
(0.00)\end{array}$ & $\begin{array}{r}50 \\
(0.00)\end{array}$ \\
\hline Applied for loans and receive it & 9 & 3 & 4 & 12 & 10 \\
\hline $\begin{array}{l}\text { Applied for loans and don't } \\
\text { receive it }\end{array}$ & 4 & 0 & 8 & 5 & 3 \\
\hline Didn't apply for loans & $\begin{array}{r}88 \\
(0.00)\end{array}$ & $\begin{array}{r}97 \\
(0.00)\end{array}$ & $\begin{array}{r}88 \\
(0.00)\end{array}$ & $\begin{array}{r}83 \\
(0.00)\end{array}$ & $\begin{array}{r}87 \\
(0.00)\end{array}$ \\
\hline Received credit from other sources & - & 47 & 40 & 46 & 43 \\
\hline Received credit from public banks & 50 & 40 & 0 & 17 & 39 \\
\hline Received credit from private banks & $\begin{array}{r}50 \\
(0.02)\end{array}$ & $\begin{array}{r}13 \\
(0.02)\end{array}$ & $\begin{array}{r}60 \\
(0.02)\end{array}$ & $\begin{array}{r}37 \\
(0.02)\end{array}$ & $\begin{array}{r}17 \\
(0.02)\end{array}$ \\
\hline \multirow[t]{2}{*}{ Had a debit card } & 18 & 16 & 44 & 24 & 40 \\
\hline & $(0.00)$ & $(0.00)$ & $(0.00)$ & $(0.00)$ & $(0.00)$ \\
\hline Had a credit card & $\begin{array}{r}19 \\
(0.04)\end{array}$ & $\begin{array}{r}10 \\
(0.04)\end{array}$ & $\begin{array}{r}16 \\
(0.04)\end{array}$ & $\begin{array}{r}22 \\
(0.04)\end{array}$ & $\begin{array}{r}16 \\
(0.04)\end{array}$ \\
\hline Used cash for all payments & 89 & 81 & 74 & 79 & 79 \\
\hline $\begin{array}{l}\text { Used credit card or debit card } \\
\text { for all payments }\end{array}$ & 10 & 12 & 11 & 2 & 7 \\
\hline Used transfer or direct deposits & $\begin{array}{r}2 \\
(0.00)\end{array}$ & $\begin{array}{r}7 \\
(0.00)\end{array}$ & $\begin{array}{r}15 \\
(0.00)\end{array}$ & $\begin{array}{r}20 \\
(0.00)\end{array}$ & $\begin{array}{r}14 \\
(0.00)\end{array}$ \\
\hline $\begin{array}{l}\text { Made the major part of payments } \\
\text { at other points services }\end{array}$ & 68 & 57 & 34 & 58 & 71 \\
\hline $\begin{array}{l}\text { Made the major part of payments } \\
\text { at private banks }\end{array}$ & 11 & 11 & 9 & 22 & 10 \\
\hline
\end{tabular}


Table B.11. Analysis of Demand-Urban Survey of Access and Geographic Location (Continued)

\begin{tabular}{lrrrrr}
\hline & Northeast & North & Center-west & Southeast & South \\
\hline $\begin{array}{l}\text { Made the major part of payments } \\
\text { at public banks and lottery shops }\end{array}$ & 21 & 32 & 58 & 20 & 19 \\
$\begin{array}{l}\text { Made the major part of payments } \\
\text { at bank in person }\end{array}$ & 23 & 50 & 61 & 23 & 53 \\
$\begin{array}{l}\text { Made the major part of payments } \\
\text { by other methods }\end{array}$ & 77 & 50 & 39 & 77 & 48 \\
& $(0.00)$ & $(0.00)$ & $(0.00)$ & $(0.00)$ & $(0.00)$ \\
\hline
\end{tabular}

Note: Numbers indicate percentage frequencies in each category. $P$-values of chi-square tests of independence are cited below the frequencies in parentheses. $P$-values below 0.05 are statistically significant. Source: World Bank staff estimates; Survey of Access to Financial Services in Urban Areas of Brazil, 2002. 
Table B.12. Analysis of Demand-Urban Survey of Access and Location

\begin{tabular}{|c|c|c|c|c|c|c|c|c|}
\hline & \multicolumn{2}{|c|}{ 1. Area } & \multicolumn{2}{|c|}{ 2. House } & \multicolumn{2}{|c|}{ 3. Construction } & \multicolumn{2}{|c|}{ 4. Rooms } \\
\hline & Illegal & Legal & Unique & Collective & $\begin{array}{l}\text { Regular home/ } \\
\text { apartment }\end{array}$ & $\begin{array}{l}\text { Shack/ } \\
\text { room }\end{array}$ & $\begin{array}{l}>2 \text { rooms } \\
\text { per person }\end{array}$ & $\begin{array}{l}<0.5 \text { rooms } \\
\text { per person }\end{array}$ \\
\hline Had a Bank Account & $\begin{array}{r}37 \\
(0.01)\end{array}$ & $\begin{array}{r}45 \\
(0.01)\end{array}$ & $\begin{array}{r}43 \\
(0.81)\end{array}$ & $\begin{array}{r}38 \\
(0.81)\end{array}$ & $\begin{array}{r}45 \\
(0.00)\end{array}$ & $\begin{array}{r}34 \\
(0.00)\end{array}$ & $\begin{array}{r}55 \\
(0.00)\end{array}$ & $\begin{array}{r}13 \\
(0.00)\end{array}$ \\
\hline Used banks as their primary financial institution & 45 & 47 & 46 & 53 & 47 & 40 & 56 & 32 \\
\hline $\begin{array}{l}\text { Used correspondents banks as the primary financial } \\
\text { institution }\end{array}$ & 53 & 50 & 50 & 44 & 49 & 59 & 40 & 64 \\
\hline Used mainly Non-Bank Institutions & $\begin{array}{r}3 \\
(0.51)\end{array}$ & $\begin{array}{r}4 \\
(0.51)\end{array}$ & $\begin{array}{r}4 \\
(0.5)\end{array}$ & $\begin{array}{r}3 \\
(0.51)\end{array}$ & $\begin{array}{r}4 \\
(0.01)\end{array}$ & $\begin{array}{r}1 \\
(0.01)\end{array}$ & $\begin{array}{r}4 \\
(0.00)\end{array}$ & $\begin{array}{r}4 \\
(0.00)\end{array}$ \\
\hline Used mainly Private Banks & 30 & 31 & 31 & 27 & 33 & 23 & 39 & 19 \\
\hline Used mainly Public Banks & $\begin{array}{r}70 \\
(0.53)\end{array}$ & $\begin{array}{r}69 \\
(0.53)\end{array}$ & $\begin{array}{r}69 \\
(0.37)\end{array}$ & $\begin{array}{r}73 \\
(0.37)\end{array}$ & $\begin{array}{r}67 \\
(0.00)\end{array}$ & $\begin{array}{r}77 \\
(0.00)\end{array}$ & $\begin{array}{r}61 \\
(0.00)\end{array}$ & $\begin{array}{r}81 \\
(0.00)\end{array}$ \\
\hline Reached the Financial Institution on foot & $\begin{array}{r}59 \\
(0.02)\end{array}$ & $\begin{array}{r}52 \\
(0.02)\end{array}$ & $\begin{array}{r}54 \\
(0.01)\end{array}$ & $\begin{array}{r}74 \\
(0.01)\end{array}$ & $\begin{array}{r}52 \\
(0.17)\end{array}$ & $\begin{array}{r}58 \\
(0.17)\end{array}$ & $\begin{array}{r}52 \\
(0.06)\end{array}$ & $\begin{array}{r}62 \\
(0.06)\end{array}$ \\
\hline Had a Saving or a Current or a Term Deposit Account & $\begin{array}{r}23 \\
(0.01)\end{array}$ & $\begin{array}{r}30 \\
(0.01)\end{array}$ & $\begin{array}{r}29 \\
(0.03)\end{array}$ & $\begin{array}{r}19 \\
(0.03)\end{array}$ & $\begin{array}{r}30 \\
(0.00)\end{array}$ & $\begin{array}{r}20 \\
(0.00)\end{array}$ & $\begin{array}{r}41 \\
(0.00)\end{array}$ & $\begin{array}{r}7 \\
(0.00)\end{array}$ \\
\hline Had deposits in Public Sector & 9 & 15 & 14 & 7 & 15 & 11 & 18 & 3 \\
\hline Had deposits in Private Sector & 17 & 19 & 19 & 24 & 20 & 14 & 28 & 6 \\
\hline Had deposits in Other Sectors & 1 & 2 & 2 & 3 & 2 & - & 3 & 1 \\
\hline Didn't have deposits & $\begin{array}{r}73 \\
(0.00)\end{array}$ & $\begin{array}{r}64 \\
(0.00)\end{array}$ & $\begin{array}{r}65 \\
(0.28)\end{array}$ & $\begin{array}{r}66 \\
(0.28)\end{array}$ & $\begin{array}{r}64 \\
(0.00)\end{array}$ & $\begin{array}{r}75 \\
(0.00)\end{array}$ & $\begin{array}{r}51 \\
(0.00)\end{array}$ & $\begin{array}{r}90 \\
(0.00)\end{array}$ \\
\hline Received credit from other sources & 48 & 44 & 43 & 67 & 45 & 45 & 42 & 100 \\
\hline Received credit from public banks & 10 & 25 & 23 & 17 & 26 & 6 & 30 & - \\
\hline Received credit from private banks & $\begin{array}{r}41 \\
(0.18)\end{array}$ & $\begin{array}{r}30 \\
(0.18)\end{array}$ & $\begin{array}{r}34 \\
(0.17)\end{array}$ & $\begin{array}{r}17 \\
(0.17)\end{array}$ & $\begin{array}{r}29 \\
(0.02)\end{array}$ & $\begin{array}{r}48 \\
(0.02)\end{array}$ & $\begin{array}{r}28 \\
(0.25)\end{array}$ & $\overline{(0.25)}$ \\
\hline
\end{tabular}


Applied for a loan and received it

Applied for a loan and didn't receive it

Had a debit card

Had a credit card

Used cash for all payments

Used credit card or debit card for all payments

Used transfer or direct deposits

Made majority of payments at other points services

Made majority of payments at private banks

Made majority of payments at public banks and

lottery shops

Made majority of payments at bank in person

Made majority of payments by other methods
Didn't apply for a loan

\begin{tabular}{|c|c|c|c|c|c|c|c|}
\hline 8 & 11 & 10 & 15 & 11 & 9 & 13 & 1 \\
\hline 6 & 5 & 5 & 20 & 4 & 6 & 4 & 5 \\
\hline 86 & 84 & 85 & 65 & 85 & 85 & 83 & 94 \\
\hline (0.16 & $(0.16$ & $(0.00)$ & $(0.00)$ & $(0.19)$ & $(0.19)$ & $(0.02)$ & $(0.02)$ \\
\hline 24 & 26 & 26 & 10 & 26 & 22 & 34 & 5 \\
\hline (0.59) & $(0.59)$ & $(0.37)$ & $(0.37)$ & $(0.17)$ & $(0.17)$ & $(0.00)$ & $(0.00)$ \\
\hline 17 & 21 & 20 & 14 & 21 & 16 & 25 & 6 \\
\hline$(0.16)$ & $(0.16)$ & $(0.47)$ & $(0.47)$ & $(0.00)$ & $(0.00)$ & $(0.00)$ & $(0.00)$ \\
\hline 84 & 75 & 76 & 79 & 75 & 85 & 69 & 91 \\
\hline 8 & 10 & 10 & 11 & 10 & 9 & 11 & 7 \\
\hline $\begin{array}{r}8 \\
(0.00)\end{array}$ & $\begin{array}{r}15 \\
(0.00)\end{array}$ & $\begin{array}{r}14 \\
(0.28)\end{array}$ & $\begin{array}{r}11 \\
(0.28)\end{array}$ & $\begin{array}{r}15 \\
(0.00)\end{array}$ & $\begin{array}{r}6 \\
(0.00)\end{array}$ & $\begin{array}{r}20 \\
(0.02)\end{array}$ & $\begin{array}{r}1 \\
(0.02)\end{array}$ \\
\hline 24 & 25 & 25 & 12 & 26 & - & 23 & 33 \\
\hline 16 & 18 & 17 & 24 & 17 & 67 & 23 & 5 \\
\hline $\begin{array}{r}60 \\
(0.01)\end{array}$ & $\begin{array}{r}58 \\
(0.01)\end{array}$ & $\begin{array}{r}58 \\
(0.21)\end{array}$ & $\begin{array}{r}65 \\
(0.21)\end{array}$ & $\begin{array}{r}56 \\
(0.00)\end{array}$ & $\begin{array}{r}33 \\
(0.00)\end{array}$ & $\begin{array}{r}55 \\
(0.01)\end{array}$ & $\begin{array}{r}62 \\
(0.01)\end{array}$ \\
\hline 47 & 56 & 54 & 63 & 55 & 50 & 55 & 44 \\
\hline $\begin{array}{r}53 \\
(0.00)\end{array}$ & $\begin{array}{r}44 \\
(0.00)\end{array}$ & $\begin{array}{r}46 \\
(0.06)\end{array}$ & $\begin{array}{r}37 \\
(0.06)\end{array}$ & $\begin{array}{r}45 \\
(0.33)\end{array}$ & $\begin{array}{r}50 \\
(0.33)\end{array}$ & $\begin{array}{r}45 \\
(0.29)\end{array}$ & $\begin{array}{r}56 \\
(0.29)\end{array}$ \\
\hline
\end{tabular}

Note: Numbers indicate percentage frequencies in each category. $P$-values of chi-square tests of independence are cited below the frequencies in parentheses. $P$-values below 0.05 are statistically significant.

Source: World Bank staff estimates; Survey of Access to Financial Services in Urban Areas of Brazil, 2002. 
Table B.13. Analysis of Demand-Urban Survey of Access to Financial Institutions

\begin{tabular}{|c|c|c|c|c|c|c|}
\hline & \multicolumn{3}{|c|}{$\begin{array}{c}\text { Banks-Narrow } \\
\text { Definition }\end{array}$} & \multicolumn{3}{|c|}{$\begin{array}{c}\text { Banks-Including } \\
\text { Correspondents }\end{array}$} \\
\hline & Private $^{1}$ & Public $^{1}$ & Test $^{3}$ & Private $^{2}$ & Public $^{2}$ & Test $^{3}$ \\
\hline \multicolumn{7}{|l|}{ Geographic Region } \\
\hline North & 50 & 50 & 0.01 & 16 & 84 & 0.00 \\
\hline Northeast & 48 & 52 & 0.01 & 27 & 73 & 0.00 \\
\hline Center & 58 & 42 & 0.01 & 28 & 72 & 0.00 \\
\hline Southeast & 62 & 38 & 0.01 & 34 & 66 & 0.00 \\
\hline South & 48 & 52 & 0.01 & 26 & 74 & 0.00 \\
\hline \multicolumn{7}{|l|}{ Area } \\
\hline Illegal areas 3 & 58 & 42 & 0.46 & 30 & 70 & 0.53 \\
\hline Legalized area 3 & 58 & 42 & 0.46 & 31 & 69 & 0.53 \\
\hline \multicolumn{7}{|l|}{ Type of Dwelling } \\
\hline Unique permanent house & 59 & 41 & 0.61 & 31 & 69 & 0.37 \\
\hline Collective house & 50 & 50 & 0.61 & 27 & 73 & 0.37 \\
\hline \multicolumn{7}{|l|}{ Type of Building } \\
\hline House or apartment & 59 & 41 & 0.02 & 33 & 67 & 0.00 \\
\hline Cottage or rooms & 52 & 48 & 0.02 & 23 & 77 & 0.00 \\
\hline \multicolumn{7}{|l|}{ Number of Room per Person } \\
\hline More than 2 rooms for person & 63 & 37 & 0.00 & 39 & 61 & 0.00 \\
\hline Less than 0.5 rooms for person & 52 & 48 & 0.00 & 19 & 81 & 0.00 \\
\hline \multicolumn{7}{|l|}{ Gender } \\
\hline Man & 60 & 40 & 0.00 & 34 & 66 & 0.00 \\
\hline Woman & 56 & 44 & 0.00 & 28 & 72 & 0.00 \\
\hline \multicolumn{7}{|l|}{ Role in Household } \\
\hline Head of household & 60 & 40 & 0.10 & 32 & 68 & 0.43 \\
\hline Dependent & 56 & 44 & 0.10 & 30 & 70 & 0.43 \\
\hline \multicolumn{7}{|l|}{ Income } \\
\hline Lowest quintile & 51 & 49 & 0.00 & 22 & 78 & 0.00 \\
\hline Highest quintile & 64 & 36 & 0.00 & 49 & 51 & 0.00 \\
\hline \multicolumn{7}{|l|}{ Wealth/Collateral } \\
\hline Possessing house or car & 60 & 40 & 0.02 & 36 & 67 & 0.00 \\
\hline Without collateral & 50 & 50 & 0.02 & 25 & 75 & 0.00 \\
\hline \multicolumn{7}{|l|}{ Education Level } \\
\hline Less than primary & 57 & 43 & 0.00 & 26 & 74 & 0.00 \\
\hline More than Secondary & 69 & 31 & 0.00 & 59 & 41 & 0.00 \\
\hline \multicolumn{7}{|l|}{ Having a Job } \\
\hline Having a job in the last month & 59 & 41 & 0.00 & 33 & 67 & 0.04 \\
\hline Not having a job in the last month & 57 & 43 & 0.00 & 29 & 71 & 0.04 \\
\hline
\end{tabular}


Table B.13. Analysis of Demand-Urban Survey of Access to Financial Institutions (Continued)

\begin{tabular}{|c|c|c|c|c|c|c|}
\hline & \multicolumn{3}{|c|}{$\begin{array}{l}\text { Banks-Narrow } \\
\text { Definition }\end{array}$} & \multicolumn{3}{|c|}{$\begin{array}{l}\text { Banks-Including } \\
\text { Correspondents }\end{array}$} \\
\hline & Private $^{1}$ & Public $^{1}$ & Test $^{3}$ & Private $^{2}$ & Public $^{2}$ & Test $^{3}$ \\
\hline \multicolumn{7}{|l|}{ Role in Workplace } \\
\hline Employer & 44 & 56 & 0.00 & 22 & 78 & 0.04 \\
\hline Self-employment & 60 & 40 & 0.00 & 35 & 65 & 0.04 \\
\hline Employee-with work certificate & 59 & 41 & 0.00 & 36 & 64 & 0.04 \\
\hline Employee-without work certificate & 58 & 42 & 0.00 & 28 & 72 & 0.04 \\
\hline \multicolumn{7}{|l|}{ Full or Part Time } \\
\hline Employed full time & 60 & 40 & 0.20 & 32 & 68 & 0.06 \\
\hline Part-time or Irregular & 58 & 42 & 0.20 & 35 & 65 & 0.06 \\
\hline
\end{tabular}

Note: Numbers indicate percentage frequencies in each category. ${ }^{1}$ Private or Public banks only. ${ }^{2}$ Private includes post office with banking services. Public includes lottery shops with banking services. ${ }^{3} P$-values of chi-square tests of independence are cited below the frequencies in parentheses. $P$-values below 0.05 are statistically significant.

Source: World Bank staff estimates; Survey of Access to Financial Services in Urban Areas of Brazil, 2002. 


\section{Table B.14. Analysis of Demand_-Urban Survey of Access to Deposit, Payment, and Credit Facilities}

\begin{tabular}{|c|c|c|c|c|c|c|c|c|c|c|c|c|c|}
\hline & \multicolumn{5}{|c|}{ Deposits } & \multicolumn{4}{|c|}{ Payments } & \multicolumn{4}{|c|}{ Credit } \\
\hline & Public & Private & Other & None & Test $^{1}$ & $\begin{array}{c}\text { Public banks or } \\
\text { lottery shops }\end{array}$ & $\begin{array}{l}\text { Private } \\
\text { banks }\end{array}$ & Other & Test $^{1}$ & $\begin{array}{l}\text { Informal } \\
\text { source }\end{array}$ & $\begin{array}{l}\text { Public } \\
\text { banks }\end{array}$ & $\begin{array}{l}\text { Private } \\
\text { banks }\end{array}$ & Test $^{1}$ \\
\hline \multicolumn{14}{|l|}{ Geographic Region } \\
\hline North & 3 & 6 & - & 90 & 0.00 & 68 & 11 & 21 & 0.00 & - & 50 & 50 & 0.02 \\
\hline Northeast & 10 & 7 & 4 & 79 & 0.00 & 57 & 11 & 32 & 0.00 & 47 & 40 & 13 & 0.02 \\
\hline Center & 21 & 30 & 10 & 39 & 0.00 & 34 & 9 & 58 & 0.00 & 40 & - & 60 & 0.02 \\
\hline Southeast & 11 & 22 & 1 & 66 & 0.00 & 58 & 22 & 20 & 0.00 & 46 & 17 & 37 & 0.02 \\
\hline South & 33 & 16 & 0 & 50 & 0.00 & 71 & 10 & 19 & 0.00 & 43 & 39 & 17 & 0.02 \\
\hline \multicolumn{14}{|l|}{ Area } \\
\hline Illegal areas 3 & 9 & 17 & 1 & 73 & 0.00 & 60 & 16 & 24 & 0.81 & 48 & 10 & 41 & 0.18 \\
\hline Legalized area 3 & 15 & 19 & 2 & 64 & 0.00 & 58 & 18 & 25 & 0.81 & 44 & 25 & 30 & 0.18 \\
\hline \multicolumn{14}{|l|}{ Type of Dwelling } \\
\hline Unique permanent house & 14 & 19 & 2 & 65 & 0.28 & 58 & 17 & 25 & 0.21 & 43 & 23 & 34 & 0.17 \\
\hline Collective house & 7 & 24 & 3 & 66 & 0.28 & 65 & 24 & 12 & 0.21 & 67 & 17 & 17 & 0.17 \\
\hline \multicolumn{14}{|l|}{ Type of Building } \\
\hline House or apartment & 15 & 20 & 2 & 64 & 0.00 & 56 & 17 & 26 & 0.00 & 45 & 26 & 29 & 0.02 \\
\hline Cottage or rooms & 11 & 14 & - & 75 & 0.00 & 67 & 17 & 17 & 0.00 & 45 & 6 & 48 & 0.02 \\
\hline \multicolumn{14}{|l|}{ Number of Room per Person } \\
\hline More than 2 rooms for person & 18 & 28 & 3 & 51 & 0.00 & 55 & 23 & 23 & 0.01 & 42 & 30 & 28 & 0.25 \\
\hline Less than 0.5 rooms for person & 3 & 6 & 1 & 90 & 0.00 & 62 & 5 & 33 & 0.01 & 100 & - & - & 0.25 \\
\hline \multicolumn{14}{|l|}{ Gender } \\
\hline Man & 17 & 22 & 2 & 59 & 0.00 & 59 & 19 & 22 & 0.00 & 43 & 20 & 37 & 0.17 \\
\hline Woman & 11 & 15 & 2 & 72 & 0.00 & 57 & 15 & 28 & 0.00 & 47 & 27 & 26 & 0.17 \\
\hline \multicolumn{14}{|l|}{ Role in Household } \\
\hline Head of household & 15 & 22 & 1 & 62 & 0.02 & 59 & 19 & 22 & 0.08 & 41 & 22 & 37 & 0.36 \\
\hline Dependent & 14 & 16 & 2 & 68 & 0.02 & 57 & 16 & 27 & 0.08 & 48 & 24 & 28 & 0.36 \\
\hline
\end{tabular}




\begin{tabular}{|c|c|c|c|c|c|c|c|c|c|c|c|c|c|}
\hline \multicolumn{14}{|l|}{ Income } \\
\hline Lowest quintile & 7 & 6 & 3 & 84 & 0.00 & 59 & 10 & 30 & 0.00 & 33 & 42 & 25 & 0.48 \\
\hline Highest quintile & 25 & 42 & 1 & 32 & 0.00 & 56 & 31 & 13 & 0.00 & 42 & 24 & 34 & 0.48 \\
\hline \multicolumn{14}{|l|}{ Wealth/Collateral } \\
\hline Possessing house or car & 14 & 20 & 2 & 64 & 0.01 & 58 & 18 & 24 & 0.08 & 41 & 26 & 33 & 0.02 \\
\hline Without collateral & 12 & 13 & 1 & 73 & 0.01 & 60 & 13 & 27 & 0.08 & 64 & 8 & 28 & 0.02 \\
\hline \multicolumn{14}{|l|}{ Education level } \\
\hline Less than primary & 9 & 10 & 3 & 78 & 0.00 & 58 & 11 & 31 & 0.00 & 52 & 17 & 30 & 0.11 \\
\hline More than Secondary & 29 & 45 & 2 & 25 & 0.00 & 41 & 38 & 21 & 0.00 & 52 & 10 & 38 & 0.11 \\
\hline \multicolumn{14}{|l|}{ Having a job } \\
\hline Having a job in the last month & 18 & 26 & 2 & 54 & 0.00 & 58 & 20 & 22 & 0.00 & 49 & 21 & 30 & 0.41 \\
\hline $\begin{array}{l}\text { Not having a job in the last } \\
\text { month }\end{array}$ & 9 & 11 & 2 & 78 & 0.00 & 58 & 13 & 29 & 0.00 & 39 & 26 & 35 & 0.41 \\
\hline \multicolumn{14}{|l|}{ Role in Workplace } \\
\hline Employer & 34 & 22 & 3 & 41 & 0.00 & 53 & 21 & 26 & 0.00 & 71 & 14 & 14 & 0.64 \\
\hline Self-employment & 14 & 29 & 3 & 54 & 0.00 & 57 & 19 & 24 & 0.00 & 54 & 17 & 29 & 0.64 \\
\hline Employee-with work certificate & 23 & 31 & 1 & 45 & 0.00 & 58 & 25 & 18 & 0.00 & 42 & 18 & 40 & 0.64 \\
\hline $\begin{array}{l}\text { Employee-without work } \\
\text { certificate }\end{array}$ & 14 & 15 & 3 & 68 & 0.00 & 61 & 17 & 23 & 0.00 & 52 & 24 & 24 & 0.64 \\
\hline \multicolumn{14}{|l|}{ Full or Part Time } \\
\hline Employed full time & 18 & 26 & 2 & 54 & 0.00 & 58 & 21 & 21 & 0.00 & 47 & 22 & 31 & 0.76 \\
\hline Part-time or Irregular & 18 & 26 & 2 & 53 & 0.00 & 59 & 18 & 23 & 0.00 & 51 & 19 & 30 & 0.76 \\
\hline
\end{tabular}

Note: Numbers indicate percentage frequencies in each category. ${ }^{1} P$-values of chi-square tests of independence are cited below the frequencies in parentheses. $P$-values below 0.05 are statistically significant.

Source: World Bank staff estimates; Survey of Access to Financial Services in Urban Areas of Brazil, 2002. 


\begin{tabular}{|c|c|c|c|c|c|c|c|c|c|c|}
\hline & \multicolumn{4}{|c|}{ Pension Contributions } & \multicolumn{6}{|c|}{ Home Purchase } \\
\hline & $\begin{array}{c}\text { Didn't } \\
\text { contribute }\end{array}$ & $\begin{array}{l}\text { Public } \\
\text { fund }\end{array}$ & $\begin{array}{l}\text { Private } \\
\text { fund }\end{array}$ & Test $^{1}$ & Savings & $\begin{array}{l}\text { Credit } \\
\text { (CEF) }\end{array}$ & $\begin{array}{l}\text { Private } \\
\text { bank }\end{array}$ & $\begin{array}{c}\text { Constr. co, } \\
\text { consortium, coop }\end{array}$ & $\begin{array}{l}\text { Family/ } \\
\text { friends }\end{array}$ & Test $^{1}$ \\
\hline \multicolumn{11}{|l|}{ Geographic Region } \\
\hline North & 89 & 11 & - & 0.00 & 70 & 10 & 10 & - & 10 & 0.02 \\
\hline Northeast & 94 & 3 & 2 & 0.00 & 53 & 6 & - & - & 22 & 0.02 \\
\hline Center & 87 & 8 & 5 & 0.00 & 49 & 9 & 3 & 5 & 5 & 0.02 \\
\hline Southeast & 96 & 2 & 2 & 0.00 & 56 & 22 & 11 & - & - & 0.02 \\
\hline South & 76 & 21 & 3 & 0.00 & 69 & 7 & 6 & 4 & - & 0.02 \\
\hline \multicolumn{11}{|l|}{ Area } \\
\hline Legalized area & 92 & 8 & - & 0.00 & 53 & 9 & 4 & 4 & 5 & 0.35 \\
\hline Illegal areas & 93 & 5 & 3 & 0.00 & 61 & 5 & - & 2 & 11 & 0.35 \\
\hline \multicolumn{11}{|l|}{ Type of Dwelling } \\
\hline Unique house & 93 & 6 & 2 & 0.82 & 57 & 8 & 4 & 3 & 5 & 0.01 \\
\hline Collective house & 97 & 3 & - & 0.82 & 25 & 50 & - & - & 25 & 0.01 \\
\hline \multicolumn{11}{|l|}{ Type of Building } \\
\hline House or apartment & 93 & 5 & 2 & 0.00 & 55 & 9 & 3 & 4 & 6 & 0.01 \\
\hline Cottage or rooms & 92 & 7 & 1 & 0.00 & 54 & 6 & 6 & 2 & 8 & 0.01 \\
\hline \multicolumn{11}{|l|}{ Number of Room per Person } \\
\hline More than 2 rooms for person & 90 & 6 & 5 & 0.01 & 58 & 13 & - & 4 & 3 & 0.09 \\
\hline Less than 0.5 rooms for person & 94 & 6 & - & 0.01 & 75 & - & - & - & 25 & 0.09 \\
\hline \multicolumn{11}{|l|}{ Gender } \\
\hline Man & 92 & 6 & 2 & 0.74 & 56 & 9 & 2 & 3 & 6 & 0.65 \\
\hline Woman & 93 & 5 & 2 & 0.74 & 53 & 8 & 5 & 5 & 7 & 0.65 \\
\hline \multicolumn{11}{|l|}{ Role in Household } \\
\hline Head of household & 91 & 6 & 3 & 0.07 & 47 & 8 & - & 2 & 9 & 0.02 \\
\hline Dependent & 94 & 4 & 2 & 0.07 & 57 & 9 & 5 & 5 & 5 & 0.02 \\
\hline
\end{tabular}




\begin{tabular}{|c|c|c|c|c|c|c|c|c|c|c|}
\hline \multicolumn{11}{|l|}{ Income } \\
\hline Lowest quintile & 96 & 3 & 1 & 0.00 & 49 & 5 & 7 & 5 & 19 & 0.05 \\
\hline Highest quintile & 82 & 11 & 7 & 0.00 & 39 & 18 & - & 7 & 7 & 0.05 \\
\hline \multicolumn{11}{|l|}{ Wealth/Collateral } \\
\hline Possessing house or car & 92 & 6 & 2 & 0.01 & 54 & 9 & 4 & 4 & 6 & 0.15 \\
\hline Without collateral & 96 & 3 & 1 & 0.01 & 62 & 4 & - & 4 & 15 & 0.15 \\
\hline \multicolumn{11}{|l|}{ Education Level } \\
\hline Less than primary & 95 & 3 & 1 & 0.00 & 40 & 12 & - & 4 & 4 & 0.02 \\
\hline More than Secondary & 79 & 11 & 10 & 0.00 & 66 & 16 & - & 13 & - & 0.02 \\
\hline \multicolumn{11}{|l|}{ Having a Job } \\
\hline Having a job in the last month & 90 & 8 & 3 & 0.00 & 57 & 10 & 3 & 1 & 7 & 0.14 \\
\hline $\begin{array}{l}\text { Not having a job in the last } \\
\text { month }\end{array}$ & 96 & 2 & 1 & 0.00 & 50 & 7 & 5 & 8 & 7 & 0.14 \\
\hline \multicolumn{11}{|l|}{ Role in Workplace } \\
\hline Employer & 68 & 22 & 11 & 0.00 & 29 & - & 14 & - & 29 & 0.05 \\
\hline Self-employment & 89 & 8 & 3 & 0.00 & 50 & 13 & 2 & 2 & 2 & 0.05 \\
\hline Employee-with work certificate & 89 & 8 & 3 & 0.00 & 51 & 11 & 2 & 6 & 9 & 0.05 \\
\hline $\begin{array}{l}\text { Employee-without work } \\
\text { certificate }\end{array}$ & 95 & 3 & 2 & 0.00 & 70 & 8 & 3 & 3 & 11 & 0.05 \\
\hline \multicolumn{11}{|l|}{ Full or Part Time } \\
\hline Employed full time & 90 & 8 & 2 & 0.00 & 61 & 8 & 3 & 7 & 4 & 0.23 \\
\hline Part-time or Irregular & 88 & 8 & 4 & 0.00 & 44 & 16 & 2 & 4 & 7 & 0.23 \\
\hline
\end{tabular}

Note: Numbers indicate percentage frequencies in each category. ${ }^{1} P$-values of chi-square tests of independence are cited below the frequencies in parentheses. $P$-values below 0.05 are statistically significant.

Source: World Bank staff estimates; Survey of Access to Financial Services in Urban Areas of Brazil, 2002. 
Table B.16. Analysis of Demand-Urban Survey on Use of a Financial Institution, Physical Access, and Deposit Facilities

\begin{tabular}{|c|c|c|c|c|c|c|c|c|c|}
\hline & \multicolumn{2}{|c|}{ Bank Account } & \multicolumn{7}{|c|}{ Access to Financial Institution } \\
\hline & $\begin{array}{c}\text { Had a } \\
\text { bank } \\
\text { account }\end{array}$ & Test $^{1}$ & Banks & $\begin{array}{c}\text { Corres- } \\
\text { pondent } \\
\text { banks }\end{array}$ & $\begin{array}{c}\text { Non- } \\
\text { bank } \\
\text { institutions }\end{array}$ & Test $^{1}$ & $\begin{array}{l}\text { Private } \\
\text { banks }\end{array}$ & $\begin{array}{l}\text { Public } \\
\text { banks }\end{array}$ & Test \\
\hline \multicolumn{10}{|l|}{ Gender } \\
\hline Male & 50 & 0.00 & 50 & 47 & 3 & 0.00 & 34 & 66 & 0.00 \\
\hline Female & 37 & 0.00 & 42 & 54 & 4 & 0.00 & 28 & 72 & 0.00 \\
\hline \multicolumn{10}{|l|}{ Role in Household } \\
\hline Head of Household & 50 & 0.00 & 48 & 50 & 3 & 0.08 & 32 & 68 & 0.43 \\
\hline Dependent & 37 & 0.00 & 44 & 52 & 4 & 0.08 & 30 & 70 & 0.43 \\
\hline \multicolumn{10}{|l|}{ Income } \\
\hline Lowest quintile & 15 & 0.00 & 34 & 61 & 5 & 0.00 & 22 & 78 & 0.00 \\
\hline Highest Quintile & 64 & 0.00 & 69 & 30 & 1 & 0.00 & 49 & 51 & 0.00 \\
\hline \multicolumn{10}{|l|}{ Wealth/Collateral } \\
\hline Possessing house or car & 45 & 0.00 & 48 & 49 & 3 & 0.02 & 33 & 67 & 0.00 \\
\hline Without collateral & 35 & 0.00 & 40 & 57 & 4 & 0.02 & 25 & 75 & 0.00 \\
\hline \multicolumn{10}{|l|}{ Education } \\
\hline Less than Primary & 28 & 0.00 & 38 & 58 & 4 & 0.00 & 26 & 74 & 0.00 \\
\hline More than Secondary & 84 & 0.00 & 83 & 16 & 1 & 0.00 & 59 & 41 & 0.00 \\
\hline \multicolumn{10}{|l|}{ Having a Job } \\
\hline $\begin{array}{l}\text { Having a job in the last } \\
\text { month }\end{array}$ & 55 & 0.00 & 50 & 47 & 2 & 0.00 & 33 & 67 & 0.04 \\
\hline $\begin{array}{l}\text { Not having a job in the } \\
\text { last month }\end{array}$ & 30 & 0.00 & 42 & 53 & 5 & 0.00 & 29 & 71 & 0.04 \\
\hline \multicolumn{10}{|l|}{ Role in Workplace } \\
\hline Employer & 63 & 0.00 & 47 & 50 & 3 & 0.00 & 22 & 78 & 0.04 \\
\hline Self-employed & 51 & 0.00 & 47 & 49 & 4 & 0.00 & 35 & 65 & 0.04 \\
\hline $\begin{array}{l}\text { Employee-with work } \\
\text { certificate }\end{array}$ & 68 & 0.00 & 58 & 41 & 1 & 0.00 & 36 & 64 & 0.04 \\
\hline $\begin{array}{l}\text { Employee—no work } \\
\text { certificate }\end{array}$ & 44 & 0.00 & 42 & 56 & 2 & 0.00 & 28 & 72 & 0.04 \\
\hline \multicolumn{10}{|l|}{ Full or Part Time } \\
\hline Employed full time & 56 & 0.00 & 49 & 50 & 1 & 0.00 & 32 & 68 & 0.06 \\
\hline Part-time or Irregular & 55 & 0.00 & 53 & 42 & 4 & 0.00 & 35 & 65 & 0.06 \\
\hline
\end{tabular}

Note: Numbers indicate percentage frequencies in each category. ${ }^{1}$-values of chi-square tests of independence are cited below the frequencies in parentheses. $P$-values below 0.05 are statistically significant. Source: World Bank staff estimates; Survey of Access to Financial Services in Urban Areas of Brazil, 2002. 


\begin{tabular}{|c|c|c|c|c|c|c|c|c|}
\hline \multicolumn{2}{|c|}{ Physical Access } & \multicolumn{2}{|l|}{ Accounts } & \multicolumn{5}{|c|}{ Deposits } \\
\hline $\begin{array}{l}\text { Reached fin. } \\
\text { institution } \\
\text { on foot }\end{array}$ & Test $^{1}$ & $\begin{array}{l}\text { Savings, } \\
\text { current or } \\
\text { term deposit }\end{array}$ & Test $^{1}$ & Public & Private & Other & $\begin{array}{c}\text { No } \\
\text { deposits }\end{array}$ & Test $^{1}$ \\
\hline 52 & 0.22 & 34 & 0.00 & 17 & 22 & 2 & 59 & 0.00 \\
\hline 55 & 0.22 & 23 & 0.00 & 11 & 15 & 2 & 72 & 0.00 \\
\hline 51 & 0.04 & 32 & 0.01 & 15 & 22 & 1 & 62 & 0.02 \\
\hline 55 & 0.04 & 26 & 0.01 & 14 & 16 & 2 & 68 & 0.02 \\
\hline 54 & 0.22 & 9 & 0.00 & 7 & 6 & 3 & 84 & 0.00 \\
\hline 47 & 0.22 & 47 & 0.00 & 25 & 42 & 1 & 32 & 0.00 \\
\hline 52 & 0.01 & 30 & 0.00 & 14 & 20 & 2 & 64 & 0.01 \\
\hline 59 & 0.01 & 22 & 0.00 & 12 & 13 & 1 & 73 & 0.01 \\
\hline 55 & 0.09 & 19 & 0.00 & 9 & 10 & 3 & 78 & 0.00 \\
\hline 43 & 0.09 & 67 & 0.00 & 29 & 45 & 2 & 25 & 0.00 \\
\hline 51 & 0.06 & 38 & 0.00 & 18 & 26 & 2 & 54 & 0.00 \\
\hline 56 & 0.06 & 19 & 0.00 & 9 & 11 & 2 & 78 & 0.00 \\
\hline 45 & 0.1 & 51 & 0.00 & 14 & 29 & 3 & 54 & 0.00 \\
\hline 54 & 0.1 & 37 & 0.00 & 34 & 22 & 3 & 41 & 0.00 \\
\hline 47 & 0.1 & 47 & 0.00 & 23 & 31 & 1 & 45 & 0.00 \\
\hline 56 & 0.1 & 25 & 0.00 & 14 & 15 & 3 & 68 & 0.00 \\
\hline 50 & 0.06 & 38 & 0.00 & 18 & 26 & 2 & 54 & 0.00 \\
\hline 55 & 0.06 & 40 & 0.00 & 18 & 26 & 2 & 53 & 0.00 \\
\hline
\end{tabular}


Table B.17. Analysis of Demand-Urban Survey of Loans and Credit and Payment Services

\begin{tabular}{|c|c|c|c|c|c|c|c|c|c|c|c|c|}
\hline & \multicolumn{4}{|c|}{ Loan Application } & \multicolumn{4}{|c|}{ Receiving Credit } & \multicolumn{4}{|c|}{ Debit and Credit Cards } \\
\hline & $\begin{array}{c}\text { Received } \\
\text { it }\end{array}$ & $\begin{array}{c}\text { Didn't } \\
\text { receive } \\
\text { it }\end{array}$ & $\begin{array}{l}\text { Didn't } \\
\text { apply }\end{array}$ & Test ${ }^{1}$ & $\begin{array}{l}\text { Other } \\
\text { sources }\end{array}$ & $\begin{array}{l}\text { Public } \\
\text { banks }\end{array}$ & $\begin{array}{l}\text { Private } \\
\text { banks }\end{array}$ & Test ${ }^{1}$ & $\begin{array}{l}\text { Had a } \\
\text { debit } \\
\text { card }\end{array}$ & & $\begin{array}{c}\text { Had a } \\
\text { credit } \\
\text { card }\end{array}$ & Test $^{1}$ \\
\hline \multicolumn{13}{|l|}{ Gender } \\
\hline Male & 11 & 5 & 84 & 0.52 & 43 & 20 & 37 & 0.17 & 30 & 0.00 & 23 & 0.00 \\
\hline Female & 10 & 5 & 85 & 0.52 & 47 & 27 & 26 & 0.17 & 21 & 0.00 & 17 & 0.00 \\
\hline \multicolumn{13}{|l|}{ Role in Household } \\
\hline Head of Household & 13 & 5 & 83 & 0.01 & 41 & 22 & 37 & 0.36 & 30 & 0.00 & 23 & 0.07 \\
\hline Dependent & 8 & 5 & 87 & 0.01 & 48 & 24 & 28 & 0.36 & 21 & 0.00 & 17 & 0.07 \\
\hline \multicolumn{13}{|l|}{ Income } \\
\hline Lowest quintile & 3 & 5 & 92 & 0.00 & 33 & 42 & 25 & 0.48 & 5 & 0.00 & 7 & 0.00 \\
\hline Highest quintile & 24 & 2 & 74 & 0.00 & 42 & 24 & 34 & 0.48 & 40 & 0.00 & 34 & 0.00 \\
\hline \multicolumn{13}{|l|}{ Wealth/Collateral } \\
\hline $\begin{array}{l}\text { Possessing house } \\
\text { or car }\end{array}$ & 11 & 4 & 85 & 0.02 & 41 & 26 & 33 & 0.02 & 27 & 0.00 & 22 & 0.00 \\
\hline Without collateral & 9 & 7 & 84 & 0.02 & 64 & 8 & 28 & 0.02 & 19 & 0.00 & 12 & 0.00 \\
\hline \multicolumn{13}{|l|}{ Education } \\
\hline Less than Primary & 10 & 5 & 85 & 0.00 & 52 & 17 & 30 & 0.11 & 15 & 0.00 & 9 & 0.00 \\
\hline More than Secondary & 23 & 1 & 76 & 0.00 & 52 & 10 & 38 & 0.11 & 54 & 0.00 & 48 & 0.00 \\
\hline \multicolumn{13}{|l|}{ Having a Job } \\
\hline $\begin{array}{l}\text { Having a job in the } \\
\text { last month }\end{array}$ & 13 & 4 & 83 & 0.00 & 49 & 21 & 30 & 0.41 & 34 & 0.00 & 26 & 0.00 \\
\hline $\begin{array}{l}\text { Not having a job in } \\
\text { the last month }\end{array}$ & 8 & 5 & 87 & 0.00 & 39 & 26 & 35 & 0.41 & 17 & 0.00 & 14 & 0.00 \\
\hline \multicolumn{13}{|l|}{ Role in Workplace } \\
\hline Employer & 18 & 5 & 77 & 0.02 & 71 & 14 & 14 & 0.64 & 39 & 0.00 & 45 & 0.00 \\
\hline Self-employed & 11 & 5 & 85 & 0.02 & 54 & 17 & 29 & 0.64 & 27 & 0.00 & 21 & 0.00 \\
\hline $\begin{array}{l}\text { Employee-with } \\
\text { work certificate }\end{array}$ & 15 & 3 & 82 & 0.02 & 42 & 18 & 40 & 0.64 & 44 & 0.00 & 32 & 0.00 \\
\hline $\begin{array}{l}\text { Employee-no work } \\
\text { certificate }\end{array}$ & 10 & 5 & 85 & 0.02 & 52 & 24 & 24 & 0.64 & 26 & 0.00 & 20 & 0.00 \\
\hline \multicolumn{13}{|l|}{ Full or Part Time } \\
\hline Employed full time & 12 & 4 & 84 & 0.01 & 47 & 22 & 31 & 0.76 & 34 & 0.98 & 26 & 0.93 \\
\hline Part-time or Irregular & 14 & 4 & 82 & 0.01 & 51 & 19 & 30 & 0.76 & 34 & 0.98 & 26 & 0.93 \\
\hline
\end{tabular}

Note: Numbers indicate percentage frequencies in each category. ${ }^{1}$-values of chi-square tests of independence are cited below the frequencies in parentheses. $P$-values below 0.05 are statistically significant. Source: World Bank staff estimates; Survey of Access to Financial Services in Urban Areas of Brazil, 2002. 


\begin{tabular}{|c|c|c|c|c|c|c|c|c|c|c|}
\hline \multicolumn{4}{|c|}{ Payment Method } & \multicolumn{4}{|c|}{ Payments-Institution Type } & \multicolumn{3}{|c|}{ Payment Location } \\
\hline Cash & $\begin{array}{l}\text { Credit card } \\
\text { or debit } \\
\text { card }\end{array}$ & $\begin{array}{l}\text { Transfer } \\
\text { or direct } \\
\text { deposits }\end{array}$ & Test $^{1}$ & $\begin{array}{l}\text { Other } \\
\text { service } \\
\text { points }\end{array}$ & $\begin{array}{c}\text { Private } \\
\text { banks }\end{array}$ & $\begin{array}{l}\text { Public banks } \\
\text { and lottery } \\
\text { shops }\end{array}$ & Test $^{1}$ & $\begin{array}{c}\text { At a } \\
\text { bank in } \\
\text { person }\end{array}$ & $\begin{array}{c}\text { Other } \\
\text { methods }\end{array}$ & Test $^{1}$ \\
\hline 76 & 10 & 14 & 0.77 & 59 & 19 & 22 & 0.00 & 56 & 44 & 0.15 \\
\hline 77 & 9 & 13 & 0.77 & 57 & 15 & 28 & 0.00 & 52 & 48 & 0.15 \\
\hline 76 & 9 & 15 & 0.37 & 59 & 19 & 22 & 0.08 & 56 & 44 & 0.05 \\
\hline 77 & 10 & 12 & 0.37 & 57 & 16 & 27 & 0.08 & 52 & 48 & 0.05 \\
\hline 82 & 9 & 8 & 0.00 & 59 & 10 & 30 & 0.00 & 45 & 55 & 0.00 \\
\hline 62 & 12 & 26 & 0.00 & 56 & 31 & 13 & 0.00 & 57 & 43 & 0.00 \\
\hline 74 & 11 & 15 & 0.00 & 58 & 18 & 24 & 0.08 & 55 & 45 & 0.01 \\
\hline 87 & 5 & 8 & 0.00 & 60 & 13 & 27 & 0.08 & 48 & 52 & 0.01 \\
\hline 90 & 6 & 4 & 0.00 & 58 & 11 & 31 & 0.00 & 45 & 55 & 0.00 \\
\hline 38 & 15 & 47 & 0.00 & 41 & 38 & 21 & 0.00 & 62 & 38 & 0.00 \\
\hline 72 & 11 & 17 & 0.00 & 58 & 20 & 22 & 0.00 & 57 & 43 & 0.01 \\
\hline 82 & 8 & 10 & 0.00 & 58 & 13 & 29 & 0.00 & 51 & 49 & 0.01 \\
\hline 51 & 14 & 34 & 0.00 & 53 & 21 & 26 & 0.00 & 74 & 26 & 0.13 \\
\hline 77 & 11 & 13 & 0.00 & 57 & 19 & 24 & 0.00 & 76 & 24 & 0.13 \\
\hline 64 & 13 & 23 & 0.00 & 58 & 25 & 18 & 0.00 & 82 & 18 & 0.13 \\
\hline 83 & 8 & 9 & 0.00 & 61 & 17 & 23 & 0.00 & 77 & 23 & 0.13 \\
\hline
\end{tabular}





\section{References}

Ando, Albert, and Franco Modigliani. 1963. "The 'Life Cycle' hypothesis of saving: Aggregate Implications and Tests." American Economic Review 53(1, part 1):55-84.

Beck, Thorsten, Ross Levine, and Norman Loayza. 2000. "Finance and the Sources of Growth.” Journal of Financial Economics 58:261-300.

Bond, Philip, and Robert Townsend. 1996. "Formal and Informal Financing in a Chicago Ethnic Neighborhood." Economic Perspectives 20(4)3-27.

Dollar, David, and Aart Kraay. 2001, "Growth is Good for the Poor.” Policy Research Working Paper No. WPS2587. World Bank.

Friedman, Milton. 1957. "The Permanent Income Hypothesis: Comment." American Economic Review 48:990-91.

Galindo, Arturo. 2001. "Creditor Rights and the Credit Market: Where do We Stand?" Working Paper 448. Inter-American Development Bank, Washington, D.C.

Galindo, Arturo, and Alejandro Micco. 2001. "Creditor Protection and Financial Cycles." Working Paper 443. Inter-American Development Bank, Washington, D.C.

Grosh, Margaret, and Paul William Glewwe. 2000. "Designing Household Survey Questionnaires for Developing Countries: Lessons from 15 Years of the Living Standards Measurement Study." Volumes 1, 2, and 3. Washington, D.C.: World Bank.

Hallberg, Kristin. 2001. "A Market-Oriented Strategy For Small and Medium-Scale Enterprises.” IFC Discussion Paper No. 40. Washington, D.C.: International Finance Corporation.

Hawkins, John, and Dubravko Mihaljek. 2001. "The Banking Industry in the Emerging Market Economies: Competition, Consolidation and Systemic Stability-An Overview." In The Banking Industry in the Emerging Market Economies: Competition, Consolidation and Systemic Stability. BIS Paper No. 4. Basel, Switzerland: BIS.

Holden, Paul, and Vassili Prokopenko. 2001. "Financial Development and Poverty Alleviation: Issues and Policy Implications for Developing and Transition Countries.” IMF Working Paper WP/01/160. Washington, D.C.: International Monetary Fund.

King, Robert G., and Ross Levine. 1993. "Finance and Growth: Schumpeter Might be Right.” Policy Research Working Paper No. 1083. Washington, D.C.: World Bank.

Mayer, Thomas. 1972. Permanent Income, Wealth, and Consumption: A Critique of the Permanent Income Theory, the Life-Cycle Hypothesis and Related Theories. Berkeley: University of California Press.

Modigliani, Franco, and Richard Brumberg. 1954. "Utility Analysis and the Consumption Function: An interpretation of cross section data within Kurihara.” New Brunswick, N.J.: Rutgers University Press.

NCIF. 2002. "Innovative Products and Services for Low-Income and Unbanked Customers." Chicago: National Community Investment Fund. 
Rajan, Raghuram G., and Luigi Zingales. 1998. "Financial Dependence and Growth." American Economic Review 71(3).

Romer, David. 1996. Advanced Macroeconomics. New York: McGraw Hill.

Unibanco. 2003. "Obstacles to Increasing Access." Presentation at World Bank seminar on Access to Financial Services, Washington D.C., February.

World Bank. 2001a. Finance for Growth: Policy Choices in a Volatile World. Policy Research Report. Washington, D.C.

- 2001b. World Development Indicators. World Bank database. Washington, D.C.

- 2002. "Survey of Access to Financial Services in Urban Areas of Brazil." Washington, D.C. Processed.

- 2004. "Brazil: Access to Financial Services." Report No. 27773-BR. Washington, D.C. February. 

Assessing Financial Access in Brazil is part of the World Bank Working Paper series. These papers are published to communicate the results of the Bank's ongoing research and to stimulate public discussion.

Access to financial services in Brazil has been relatively stable over the past ten years, despite the banking sector contraction of the late 1990s. Wide geographic variations in the supply of banking services by region and municipality are partly explained by differentials in income and population density. On a cross-country basis, Brazil does not appear to be underbanked.

Looking at the use of financial services by different groups of consumers in Brazil, differences in financial access across regions is confirmed, but differences among richer and poorer neighborhoods can be as important. Public financial institutions in Brazil, deemed to be socially responsible, appear to have served disadvantaged groups more than private banks on some measures and for some services. However, their role varies by type of service, and in the case of some services, public banks in fact may have better served the better-off groups. At the level of individuals, the most important determinants of access to financial services are socio-economic characteristics such a income, wealth, and education. This may signify that in the presence of asymmetric information, access to such services depends critically on client information, and such characteristics provide a proxy for creditworthiness.

World Bank Working Papers are available individually or by subscription, both in print and online.

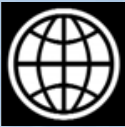

ISBN 0-8213-6131-7

THE WORLD BANK

1818 H Street, NW

Washington, DC 20433 USA

Telephone: 202 473-1000

Internet: www.worldbank.org

E-mail: feedback@worldbank.org

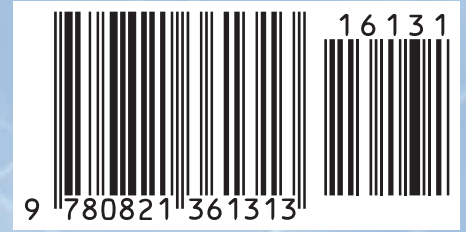

